\title{
Late Cretaceous vertebrates from Bajo de Santa Rosa (Allen Formation), Río Negro province, Argentina, with the description of a new sauropod dinosaur (Titanosauridae)
}

\author{
Agustín G. MARTINELLI ${ }^{1}$ \& Analía M. FORASIEPI ${ }^{1-2}$
}

\begin{abstract}
"Museo Argentino de Ciencias Naturales "Bernardino Rivadavia", Av. A. Gallardo 470, C1405DSR Buenos Aires, Argentina. agustin martinelli@yahoo.com.ar. 2Department of Anatomical Sciences and Neurobiology, University of Louisville. Louisville, Kentucky (40292), USA. borhyaena@hotmail.com
\end{abstract}

\begin{abstract}
A large and diverse collection of vertebrate remains from the Campanian-Maastrichtian Allen Formation (Malargüe Group) at the Bajo de Santa Rosa locality (Río Negro Province, Argentina) is described here. The vertebrates are represented by: chondrichthyans; diplomystid siluriform, lepisosteid, cf. percichthyid and dipnoid osteichthyans; pipid and leptodactylid anurans; chelid turtles; sphenodonts; elasmosaurid plesiosaurs; madtsoiid snakes; faveoolitid and megaloolithid eggshells; and hadrosaurid, $c f$ carcharodontosaurid, and titanosaurid dinosaurs. A new small saltasaurine titanosaurid, Bonatitan reigi gen. et sp. nov., is described. It is diagnosed by the following association of characters: 1) longitudinal groove located on the suture between parietals that continues posteriorly over the supraoccipital to the foramen magnum; 2) basisphenoid tubera long and narrow; 3) dorsal to middle caudal vertebrae with deep oval to circular pits present on both sides of the prespinal lamina; 4) anterior caudal vertebra with spino-postzygapophysial and spino-prezygapophysial laminae; 5) neural arch of anterior caudals with deep interzygapophysial fossae with numerous pits; 6) anterior caudal vertebra with an accessory sub-horizontal lamina extending from the antero-ventral portion of the postzygapophysis to the midmportion of the spino-prezygapophysial lamina; and finally, 7) anterior caudal vertebra with a prominent axial crest on the ventral surface of the cemtrum. The first record of sphenodonts and $c f$. carcharodontosaurid theropods is recognized for the upper Late Cretaceous of Patagonia, as well as the earliest: record of percichthyids (Perciformes). The vertebrate record is mainly composed of terrestrial and freshwater taxa, but a few marine elements are found (elasmosaurids) indicating a marine influence during the deposition of the Allen Formation in the area of Bajo de Santa Rosa. The vertebrate remains support a CampanianMaastrichtian age for the Allen Formation. Comparisons with other South American Campanian-Maastrichtian localities suggest a similar fossil vertebrate composition, with relatively few differences between the Patagonian and extra Patagonian South American records.
\end{abstract}

Key words: Late Cretaceous, osteichthyans, chondrichthyans, anurans, turtles, sphenodonts, plesiosaurs, ophidians, dinosaurs, Patagonia.

The increasing knowledge about Late Cretaceous vertebrate faunas from South America, in particular those of Argentina, is opening new windows, not only for the information based on new taxa, but also for the evolutionary, paleobiogeographic, biochronological, and compositional aspects of the Late Cretaceous continental assemblages which populated this continent. The fossil remains recovered from the CampanianMaastrichtian South American formations such as Los Blanquitos (Salta Province, Argentina; e.g., Powell, 1979, 2003), Lecho (Salta Province, Argentina; e.g., Bonaparte \& Powell, 1980; Chiappe, 1993), Yacoraite (Salta Province, Argentina; e.g., Powell, 1979; Cione et al., 1984; Cione \& Pereira, 1985; Benedetto \& Sánchez, 1971;
Gasparini \& Buffetaut, 1980; Alonso \& Marquillas, 1986), Los Alamitos (Río Negro Province, Argentina; e.g., Bonaparte et al., 1984; Bonaparte, 1986a, 1987, 1990, 1992, 1994, 2002; Báez, 1987; Broin, 1987; Albino, 1986, 1994; Cione, 1987; Salgado et al., 1997b), Loncoche (Mendoza Province, Argentina; e.g., Wichmann, 1927; González Riga, 1999), Allen (Río Negro and La Pampa, Provinces, Argentina; e.g., Powell, 1987b, Gasparini \& Salgado, 2000; Salgado \& Aspilicueta, 2000; Coria, 2001), La Colonia (Chubut Province, Argentina; e.g., Ardolino \& Franchi, 1996; Albino, 2000; Gasparini \& de la Fuente, 2000; Pascual et al., 2000), El Molino (Central and South Bolivia; e.g., Gayet et al., 1991, 2001, 2003; Gayet, 1991; Schultze, 1991a \& 
b; Gayet \& Meunier, 1998), Adamantina and Marilia (Minas Gerais and Säo Paulo States, Brazil; e.g., Gayet \& Brito, 1989; Bertini et al., 1993), and finally Asencio and Mercedes (Paysandú, Río Negro, Durazno and Soriano localities, Uruguay; e.g., Mones, 1997) show a great taxonomic diversity of vertebrates in Gondwana.

In addition, Campanian-Maastrichtian nonSouth American Gondwanan vertebrates have been found in India (e.g., Lydekker, 1877, 1879, 1887; Huene \& Matley, 1933; Berman \& Jain, 1982, Jain \& Bandyopadhyay, 1997), Madagascar (e.g., Depéret, 1896; Krause et al., 1997, 1999; Curry Rogers \& Forster, 2001; Gottfried and Krause, 1998; Sampson et al., 1998), and, though less abundant, in Australia (e.g., Rich et al., 2002), New Zeland (e.g., Molnar, 1989), and Antarctica (Gasparini \& Goñi, 1985; Olivero et al., 1991; Novas et al., 2003a) which also contribute to the knowledge of the diversity of Gondwanan biota.

During the summer of 1990, 1991, and 1994 fieldworks directed by Dr. José F. Bonaparte and carried out by staff from the Museo Argentino de Ciencias Naturales "Bernardino Rivadavia» were conducted at the Bajo de Santa Rosa locality, Río Negro Province, Argentina (Fig. 1). A rich and diverse collection of vertebrate remains was recovered from outcrops of the Allen Formation (Table 1). These fossil remains identified are: chondrichthyans; diplomystid siluriforms, lepisosteid, probably percichthyid, and dipnoid osteichthyans; pipid and leptodactylid anurans; chelid turtles; sphenodonts; elasmosaurid plesiosaurs; madtsoiid snakes; and hadrosaurid, titanosaurid, and probably carcharodontosaurid dinosaurs (Table 2).

The aim of this contribution is to describe the vertebrate fossils collected from the Allen For. mation at the Bajo de Santa Rosa locality (Fig. 1 ), and to report a new saltasalurine dinosaur, Bonatitan reigi gen. et $s p$. nov. Comments and relationships with other vertebrate-bearing formations of Campanian-Maastrichtian age from South America are discussed.

\section{LOCATION AND GEOLOGICAL SETTING}

The Bajo de Santa Rosa locality is located approximately $150 \mathrm{~km}$ south west from the city of Lamarque, approximately in the southern cen. ter of the Río Negro Province (Fig. 1). In this area, the exposed Mesozoic sedimentary rocks correspond to three Late Cretaceous formations: Bajo de la Carpa, Allen, and Jagüel (Hugo \& Leanza, 2001). The Bajo de la Carpa Formation belongs to the Río Colorado Subgroup from the Neuquén Group (Hugo \& Leanza, 2001) and its age is presumed to be Coniacian-Santonian (Legarreta \& Gulisano, 1989; Bonaparte, 1991). The Allen and Jagüel formations that correspond to the Malargue Group overlie discordantly the Bajo de la Carpa Formation. According to recent studies (Hugo \& Leanza, 2001) both the Bajo de la Carpa and Jagüel formations are poorly represented at the Bajo de Santa Rosa locality; contrary, the Allen Formation shows widely exposed outcrops (Fig. 1B).

The formations that comprise the Malargüe Group (Late Campanian-Early Paleocene sensu Legarreta \& Gulisano, 1989) vary according to their position in the Neuquén basin. In the southeast of the basin the sedimentary sequence comprises (from the base to the top respectively) the Allen, Jagüel, Roca, and El Carrizo formations. In the northwest of the basin the Malargüe Group is formed by the following units: Loncoche, Jagüel, Roca, and Pircala formations (e.g., Bar* rio, 1990).

The Jagüel Formation overlies the Allen Formation in the area of Bajo de Santa Rosa. The age inferred for the Jagüel Formation is Late Maastrichtian-Early Danian (e.g., Casadío, 1994); the Cretaceous-Paleocene transition (K-T) was recognized in the upper part of the sequence (Concheyro et al., 2002).

The Allen Formation is the first litostratigraphic unit of the Malargüe Group, Malalhueyano cycle (Riográdico supercycle) corresponding to the first Atlantic transgression ( $\mathrm{Mar}$ de Káwas"; Casamiquela, 1978) in to the Neuquén Basin (e.g., Wichmann, 1927; Casamiquela, 1978; Bertels, 1979; Uliana \& Dellapé, 1981). The Atlantic ingression extended over northern Patagonia (roughly corresponding to the limits of the Río Negro and Neuquén Provinces) reaching the south of Mendoza and La Pampa Provinces (e.g., Casamiquela, 1978; Uliana \& Dellapé, 1981; González Riga, 1999; González Riga \& Casadío, 2000).

The The Allen Formation named initially "Facies Lacustre Senoniana" by Wichmann (1927), forms part of an extensive sedimentary event influenced by the sea, in a regimen of shallow water and probably of restricted water circulation, bearing freshwater and brackish fauna (e.g., Casadio, 1994). The inferred age for the Allen Formation is disputed and has been considered Early Maastrichtian (Bertels, 1964, 1969; Legarreta \& Gulisano, 1989; Ballent, 1980), Campanian-Maastrichtian (Uliana \& Dellapé, 1981), Middle Campanian (Heredia \& Salgado, 1999), and Late Campanian-Early Maastrichtian (Barrio, 1990; Hugo \& Leanza, 2001), among others. 
Table 1. List of the specimens studied. An asterisk (*) indicates holotype specimen.

\begin{tabular}{|c|c|c|}
\hline SPECIMEN & IDENTIFICATION & MATERIALS \\
\hline MACN-PV RN 1072 & Diplomystidae indet. & 4 incomplete pectoral spines \\
\hline MACN-PV RN 1.074 & Siluriformes indet. & 4 incomplete pectoral spines \\
\hline MACN-PV RN 1084: & Siluriformes indet. & incomplete pectoral spine \\
\hline MACN-PV RN 1071 & Lepisosteidae indet. & 6 vertebral centra \\
\hline MACN-PV RN 1077 & Teleostei indet. & 10 isolated teeth \\
\hline MACN-PV RN 1081 & cf. Percichthyidae indet. & 19 fragmentary vertebrae \\
\hline MACN-PV RN 1079 & Ceratodontiformes indet. & tooth plate \\
\hline MACN-PV RN 1080 & Ceratodontiformes indet. & 2 tooth plates \\
\hline MACN-PV RN 1076 & Chondrichthyes indet. & 11 vertebral centra \\
\hline MACN-PV RN 1.064 & Pipidae indet. & sphenethmoid \\
\hline MACN-PV RN 1065 & Pipidae indet. & sphenethmoid \\
\hline MACN-PV RN 1063 & Leptodactylidae indet. & fragment of maxilla \\
\hline MACN-PV RN 1069 & Leptodactylidae indet. & 23 fragments of ormamented cranial bones \\
\hline MACN-PV RN 1066 & Leptodactylidae indet. & incomplete right humerus \\
\hline MACN-PV RN 1067 & Anura indet. & 5 incomplete vertebrae \\
\hline MACN*PV RN 1068 & Anura indet. & 5 incomplete angulosplenials \\
\hline MACN-PV RN 1070 & Anura indet. & radio and ulna \\
\hline MACN-PV RN 1089 & Chelidae indet. & fragments of caparace \\
\hline MACN-PV RN 1090 & Chelidae indet. & fragments of caparace \\
\hline MACN-PV RN 1091 & Chelidae indet. & fragments of caparace \\
\hline MACN-PV RN 1087 & Elasmosauridae indet. & $\begin{array}{l}3 \text { cervical and } 1 \text { caudal centra, and fragmentary } \\
\text { remains }\end{array}$ \\
\hline MACN-PV RN 1062 & Sphenodontidae indet. & fragment of right lower jaw \\
\hline MACN-PV RN 1049 & Patagoniophis parvus & incomplete trunk vertebra \\
\hline MACN-PV RN 1056 & Patagoniophis paruus & incomplete trunk vertebra \\
\hline MACN-PV RN 1053 & Alamitophis argentinus & incomplete trunk vertebra \\
\hline MACN PV RN 1051 & Madtsoidae indet. & incomplete trunk vertebra \\
\hline MACN-PV RN 1052 & Madtsoiidae indet. & incomplete trunk vertebra \\
\hline MACN.PV RN 1054 & Madtsoiidae indet. & incomplete trunk vertebra \\
\hline MACN.FV RN 1059 & ?Madtsoiidae indet. & incomplete trunk vertebra \\
\hline "MACN-PV RN 821 & Bonatitan reigi & $\begin{array}{l}\text { complete braincase, middle dorsal vertebra, anterior } \\
\text { caudal vertebra, middle caudal neural arch, left } \\
\text { humerus, fragment of metacarpal, both femora, both } \\
\text { tibiae, left fibula, left calcaneous, left metatarsal I }\end{array}$ \\
\hline MACN-PV RN 1061 & Bonatitan reigi & $\begin{array}{l}\text { complete braincase, incomplete anterior } \\
\text { cervicalvertebra, left radius, left uina, left femur, left } \\
\text { tibia, calcaneous, metatarsal II, and few incomplete } \\
\text { chevrons }\end{array}$ \\
\hline MACN-PV RN 1088 & Sphaerowum erbeni & 7 eggs and several fragments of eggshell \\
\hline MACN-PV RN 1096 & Megaloolithidae indet. & 8 eggs and fragments of eggshell \\
\hline MACN-PV RN 1086 & cf. Carcharodontosauridae indet. & isolated tooth \\
\hline MACN-PV RN 1085 & Hadrosauridae indet. & 5 fragments of maxilla and tooth fragments \\
\hline
\end{tabular}

Paleoenviromental studies of the Allen Formation suggest the presence of a fluvial environment in the basal section; becoming subtidal with continental influence in the middle; and finally, a marine regression is represented in the upper section, with the evaporation of shallow lagoons close to the sea (Andreis et al., 1974; Uliana and Dellapé, 1981; Barrio, 1990; Casadí, 1994; Page et al., 1999).

The Allen Formation at Bajo de Santa Rosa consists of two members each about 70 meters thick (Hugo \& Leanza, 2001). The lower member is composed of alternated sandstones and mudstones with small lents of conglomerates. The upper member is dominated by gray pelites covered by limestone and gypsum (Page et al., 1999; Hugo \& Leanza, 2001).

All the specimens described here (Table 1) were collected in the lower member of the Allen Formation exposed at Bajo de Santa Rosa (Fig. 1).

Institutional Abbreviations. MACN: Museo Argentino de Ciencias Naturales «Bernardino Rivadavia" ( $\mathrm{CH}$, Chubut Collection; $\mathrm{N}$, Neuquen Collection; PV, Paleontología de Vertebrados; RN, Río Negro Collection). 
Table 2. Systematic list of the vertebrates described here from the Allen Formation at the Bajo de Santa Rosa locality (Río Negro Province, Argentina).

\section{CLASS CHONDRICHTHYES}

Order indet.

\author{
CLASS OSTEICHTHYES \\ Subclass Actinopterygii \\ Superorder Teleostei \\ Order indet. \\ Order Siluriformes \\ Family Diplomystidae \\ Gen. et sp. indet. \\ Family indet. \\ Superorder "Holostei" \\ Order Lepisosteiformes \\ Family Lepisosteidae \\ Gen. et sp. indet. \\ Superorder Acanthopterygit \\ Order Perciformes \\ Family cf. Percichthyidae \\ Gen. et sp. indet. \\ Subclass Sarcopterygii \\ Order Ceratodontiformes \\ Family Ceratodontidae \\ Gen. et sp. indet.

\section{CLASS AMPHIBIA} \\ Order Anura \\ Family Pipidae \\ Gen. et sp. indet. \\ Family Leptodactylidae \\ Gen, et sp, indet. \\ Family indet.

\section{CLASS REPTILIA} \\ Subclass Testudinata \\ Order Chelonia \\ Suborder Pleurodira \\ Family Chelidae \\ Gen. et sp. indet. I \\ Gen. et sp. indet. 2 \\ Gen. et sp. indet. 3
}

\section{SYSTEMATIC PALEONTOLOGY}

\section{OSTEICHTHYANS}

Freshwater osteichthyan remains are a common element in the lower member of the Allen Formation at Bajo de Santa Rosa. Despite the fragmentary and isolated nature of these specimens, at least five families were recognized. Comparisons with previously known taxa were carried out, specially with those fishes recovered in the Coli Toro, Yacoraite, Los Alamitos, and Loncoche formations (Cione \& Laffite, 1980; Cione \& Pereira, 1985; Cione et al., 1984; Cione, 1987; González Riga, 1999), the Bauru Group (Gayet \& Brito,

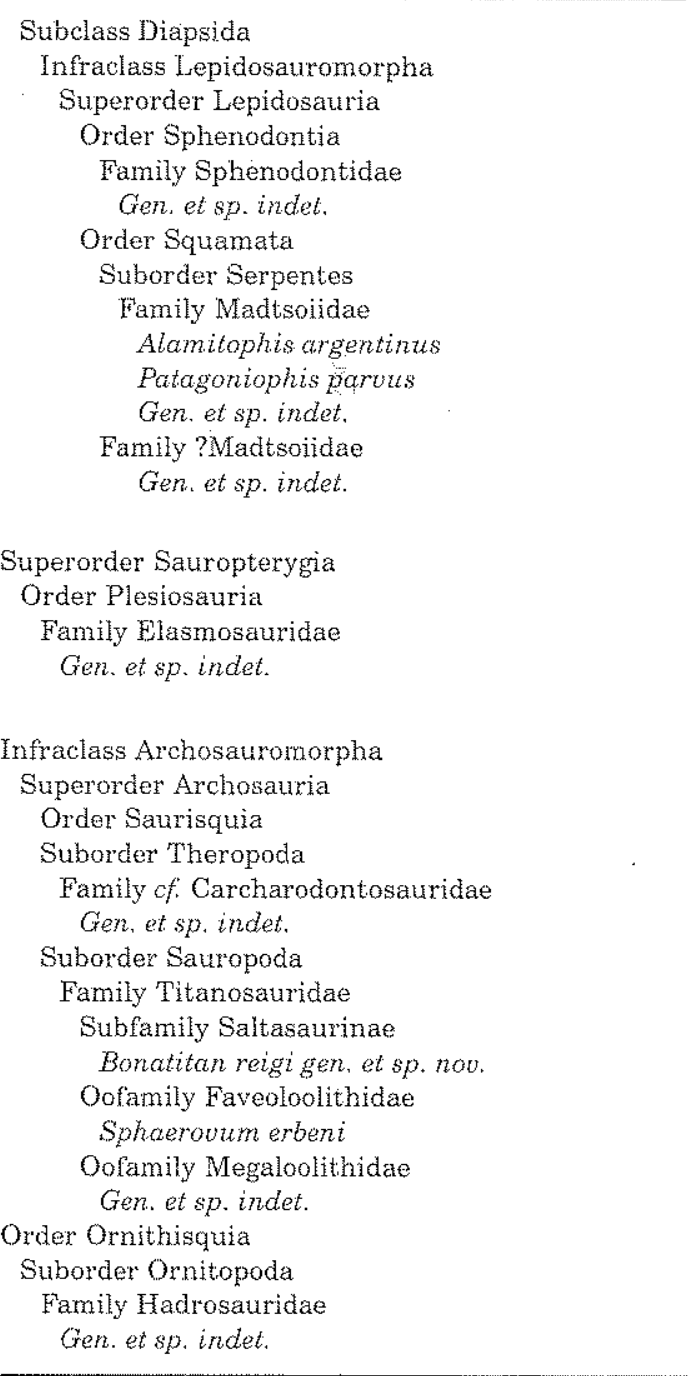

1989; Bertini et al., 1993), and continental Cretaceous-Early Tertiary formations of Bolivia (e.g., Gayet, 1991; Gayet \& Meunier, 1998).

\section{Osteichthyes Howes, 1894 \\ Siluriformes (sensu Chardon, 1968)}

Cretaceous freshwater siluriforms are known in South America only by fragmentary and isolated remains. They were reported in the Late Cretaceous Yacoraite Formation (Salta Province; Cione \& Pereira, 1985; Cione et al., 1984), Coli Toro, Los Alamitos, and La Colonia formations (Patagonia; Cione \& Laffite, 1980; Cione, 1987; Bovcon, 2002), El Molino Formation (Bolivia; 

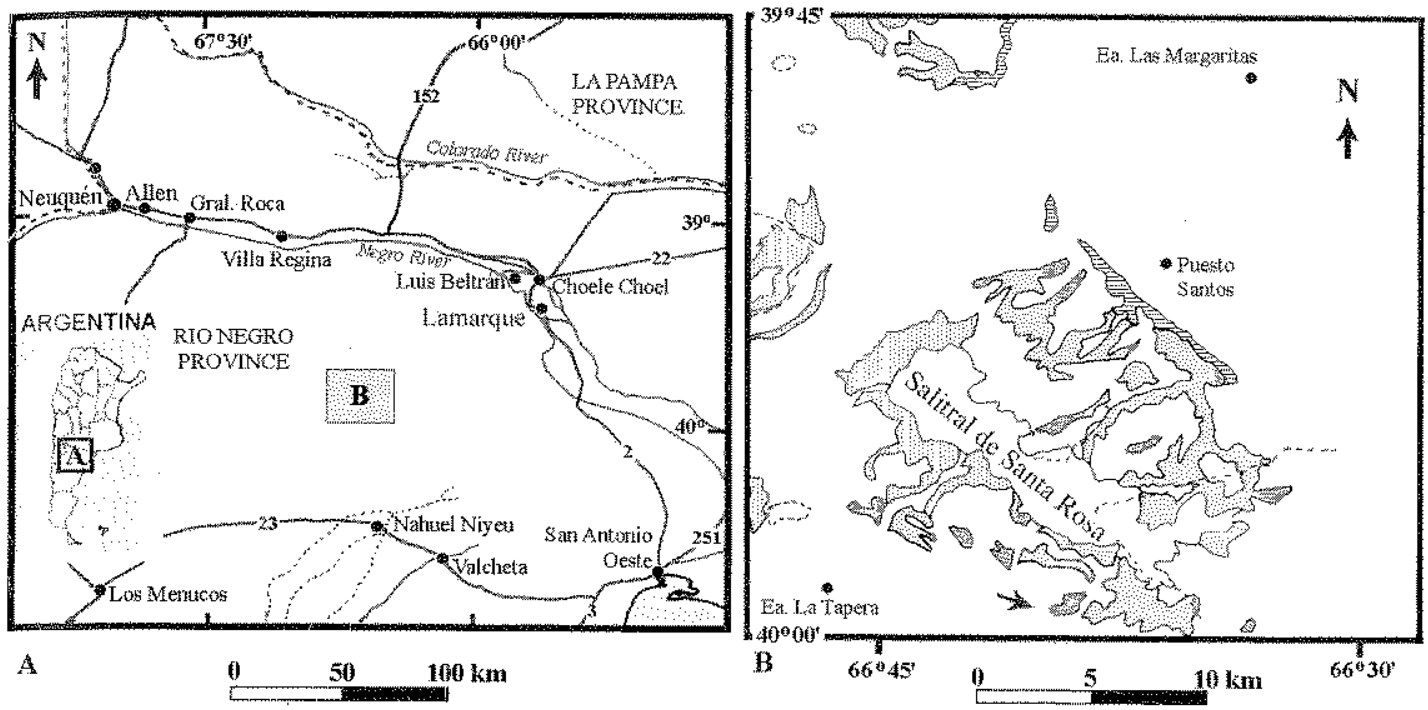

Fig. 1. A. Location map of the Bajo de Santa Rosa locality, Río Negro Province, Argentina; B. geological map at Bajo de Santa Rosa (modified from Hugo \& Leanza, 2001). Regular dots indicate the outerops of the Bajo de la Carpa Formation; grey pattern indicates the Allen Formation; and horizontal stripes indicate the Jagüel Formation. The arrow shows outcrops at Bajo de Santa Rosa where the fossils were collected.

Wenz, 1969; Gayet \& Meunier, 1998; Gayet et al., 2001), and in the Bauru Group (Brazil; Gayet \& Brito, 1989; Bertini et al., 1993). Non-South American Cretaceous siluriforms are known from the Maastrichtian of Niger (Patterson, 1993), Spain (de la Pena \& Soler-Gujón, 1995), India (Cione \& Prasad, 2002), and possibly United States (Frizzell \& Koenig, 1973).

Up to now, the only families recognized in the Cretaceous of South America are the Diplomystidae, Ariidae, Andinichthyidae, and possible Doradidae, but due to the fragmentary nature of most of the specimens referred to these families, further studies and materials are required to confirm these interpretations (Arratia \& Cione, 1996; Cione \& Prasad, 2002).

\section{Diplomystidae Eigenman 1890 Gen.et $s p$, indet.} (Fig. 2A)

Referred Material. MACN.PV RN 1072: four incomplete pectoral spines.

Description. All the pectoral spines have well developed radial striae on the proximal articular surfaces and lack an anterior denticulation (diagnostic features of Diplomystidae; Gayet \& Meunier, 1998). The specimen herein figured (Fig. 2A) has an elongate dorsal process (following the terminology of Hubbs \& Hibbard, 1951) as it is present in the Diplomystidae from the Maastrichtian of Bolivia (Gayet \& Meunier, 1998). The denticles are developed only on the posterior margin; they are smaller and more rounded than in the indeterminate siluriform MACN-PV RN 1074 (Fig. 2C). The denticles begin at a short distance of the large posterior foramen.

Comments. The Diplomystidae is an aneient group of Siluriformes endemic of South America (Cione, 1987) which was also reported in the Late Cretaceous of Los Alamitos (Cione, 1987), La Colonia (Bovcon, 2002), and El Molino formations (Gayet \& Meunier, 1998).

\section{Siluriformes (sensu Chardon, 1968) incertae sedis}

(Figs. 2B, C)

Referred Material. MACN-PV RN 1074: four very small incomplete pectoral spines (Fig. $2 \mathrm{C}$ ). MACN-PV RN 1084: incomplete pectoral spine lacking its proximal portion (Fig. 2B),

Description. Despite their fragmentary nature, these remains show differences with the catfish (Diplomystidae) remains commented above. The specimen MACN-PV RN 1084 represents the largest siluriform from Bajo de Santa Rosa (Fig. 2B). The spine is slightly curved, lacks anterior denticles, with the small posterior ones 

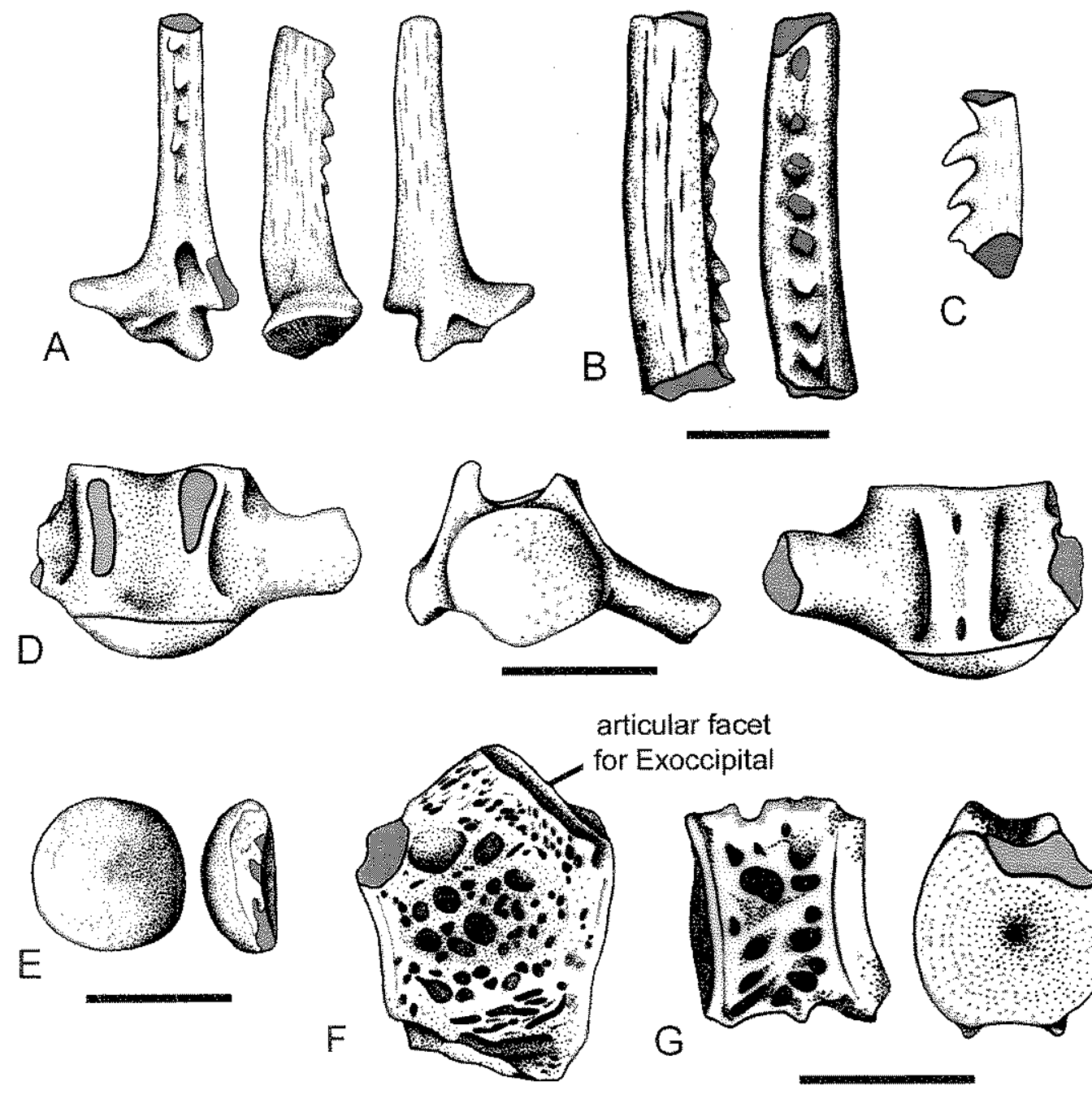

$\mathrm{G}$
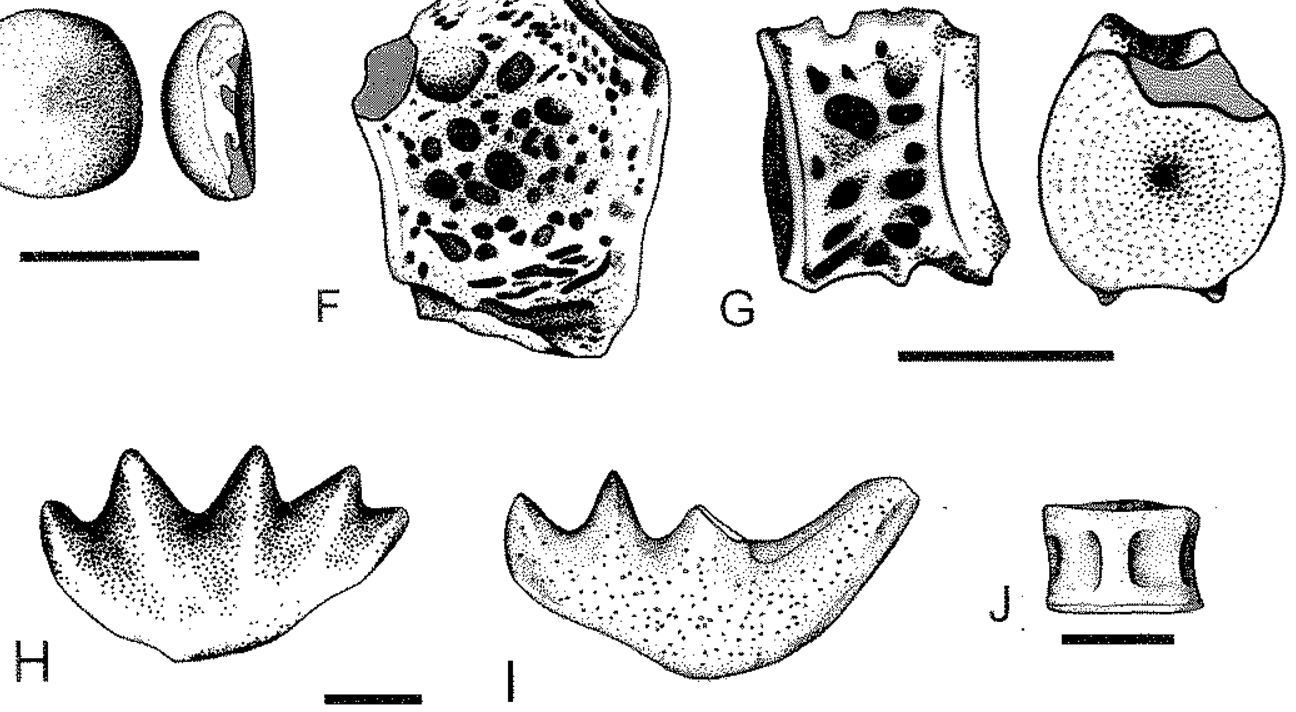

Fig. 2. Osteichthyans. A. MACN-PV RN 1072, right pectoral spine of Diplonystidae indet. in posterior, dorsal and anterior views; B. MACN-PV RN 1084, fragment of pectoral spine of Siluriformes indet. in dorsal and posterior views; C. MACN.PV RN 1074, fragment of pectoral spine of Siluriformes indet. in dorsal view; D. MACN-PV RN 1071, vertebra of Lepisosteidae indet. in dorsal, anterior and ventral views; E. MACN-PV RN 1077, tooth plate of Teleostei indet. in occlusal and lateral views; $\mathrm{F}$. MACN-PV RN 1081, anteriormost vertebra of cf. Percichthyidae indet, in lateral view; G. MACNPV 1081, vertebra of $c f$. Percichthyidae indet. in lateral and anterior views; H. MACN-PV RN 1079, tooth plate of Ceratodontiformes indet, in occlusal view; I. MACN-PV RN 1080, tooth plate of Ceratodontiformes indet. in occlusal view. Chondrichthyans. J. MACN-PV RN 1076, vertebra of Chondrichthyes indet. Scale bar represents $5 \mathrm{~mm}$. Grey pattern indicates broken areas. 
located in a longitudinal groove. The spine is almost circular in cross-section and the dorsal and ventral surfaces are covered with shallow longi. tudinal furrows.

In the four specimens catalogued as MACNPV RN 1074, the proximal portion of the spine is missing. The denticles are located only on one edge (possibly the posterior margin); they are sharp, inclined, and as long as the spine width (Fig. 2C). A similar type of pectoral spine has been also discovered in the siluriforms from the Los Alamitos Formation (Cione, 1987: Fig 1B).

At the moment, these fossil remains are referred to Siluriformes incertae sedis. At least three different morphologies were identified that could be related to different siluriform taxa.

\section{Lepisosteiformes Hay, 1926 Lepisosteidae Cuvier, 1825 Gen. et sp. indet.} (Fig. 2D)

Referred Material. MACN-PV RN 1071: six vertebral centra (Fig. 2D).

Description. At least six incomplete vertebrae were found at Bajo de Santa Rosa. The vertebral apophyses have not been preserved in most specimens. All the vertebrae show the diagnostic feature of Lepisosteidae in having an opisthocoelous centrum (Cione, 1987).

Comments. In South America, lepisosteids have been documented in the Late Cretaceous Bauru Group (Grayet \& Brito, 1989; Bertini et al., 1993), El Molino (Gayet et al., 2001), Los Alamitos (Cione, 1987; El Abra locality, Gayet et al., 1991), and Loncoche (González Riga, 1999) formations. The earliest records of this family have been found in the Early Cretaceous of Africa (Paralepidosteus africanus; Arambourg \& Joleaud, 1943) and Brazil (Obaichthys; Wenz \& Brito, 1992).

$$
\begin{gathered}
\text { Teleostei Müller, } 1844 \\
\text { incertae sedis }
\end{gathered}
$$

(Fig. 2E)

Referred Material, MACN-PV RN 1077: ten hemispherical teeth of different sizes.

Description. The teeth are hemispherical and circular shaped (Fig. 2E). Their diameters vary from 6 to 15 millimeters.

Comments. Similar teeth, although smaller, have also been found in Los Alamitos and Loncoche formations (Cione, 1987; González Riga, 1999). This kind of tooth was originally assigned to Semionitidae (?Lepidotes sp.) or Sparidae (Cione, 1987) but later studies consid- ered it to be Teleostei incertae sedis (Cione, personal communication in González Riga, 1999).

Perciformes Bleeker, 1859

cf. Percichthyidae Jordan \& Eigenman, 1890

Gen. et sp. indet.

(Figs. 2F-G)

Referred Material. MACN-PV RN 1081: nineteen fragmentary vertebrae.

Description. One of these remains corresponds to an anteriormost vertebra due to the presence of the articular surface for the exoccipital (only preserving the right one), which faces antero-dorsally (following Arratia, 1982). The neural arch and spine are autogenous. The postzygapophyses are broken off and behind this region there is a large circular depression possibly for rib articulation (Gayet, 1987; Fig. 2F). The anterior surface of the centrum is larger than the posterior one. In all centra (Figs. 2F, G), there are numerous deep cavities of different shapes and sizes on the lateral and ventral surfaces, separated by bony trabeculae (Figs. $2 F, G$ ). The vertebral centra range from 2 to 9 millimeters in diameter.

Comments. The autogenous neural arch is a characteristic feature of the Perciformes (Gayet, 1987). The pattern of ornamentation with deep cavities in the vertebral centra is common in two families of Perciformes: Centropomidae and Percichithyidae (e.g., Arratia, 1982; Gayet, 1987, 1991). The Centropomidae are tentatively recognized in the Paleocene of Tiupampa (Bolivia) (Muizon et al, 1983; Gayet, 1991; Arratia \& Cione, 1996), while the Percichthyidae are known from the Maastrichtian of Bolivia (Gayet \& Meunier, 1998; Gayet et al., 2001), the Eocene and Miocene of Argentina and Chile (Schaeffer, 1947; Arratia \& Cione, 1996), and Oligocene-Miocene of Brazil (Arratia, 1982). Remains tentatively referred to Centropomidae or Percich-thyidae were also reported from the Marília Formation (Bertini et al., 1993), but further studies must be performed to clarify their taxonomic status. The living freshwater Percichthyidae are represented by six species belonging to the genus Percichthys that inhabit the southern and western regions of Argentina and Chile (e.g., Arratia, 1982).

We tentatively assign the fossils of Bajo de Santa Rosa to the basal family of percoids Percichthyidae because they share a similar vertebral morphology with those Percichthyidae such as Macquaria antiquus (Gayet, 1987) and the living Percichthys trucha (Arratia, 1982: 18), especially in the morphology of the anteriormost vertebra. These vertebral remains from the Allen 
Formation possibly represent the earliest record of Percichthyidae in the Campanian-Maastrichtian of South America. However, a wide. range of comparison among other basal families of percoids must be done to clarify the taxonomy of these remains.

Perciformes have also been found in the Los Alamitos (Cione, 1987), Loncoche (González Riga, 1999), and Saldeño formations (Saldenioichthys remotus; López-Arbarello et al., 2003) but a familiar assignation to these remains has not been indicated.

\section{Dipnoi Müller, 1844 \\ Ceratodontiformes Berg, 1940 \\ Ceratodontidae Gill, 1872 \\ Gen. et sp. indet. \\ (Figs. 2 H-I)}

Referred Material. MACN-PV RN 1079: left tooth plate (Fig. 2I). MACN-PV RN 1080: two tooth plates (Fig. 2H).

Description. MACN-PV RN 1079 specimen has four ridges (Fig. 21). The first ridge is the largest and the others decrease in size toward the medial edge (following the terminology of Martin et al., 1999); the second ridge is broken. The first crest is tall and sharp. The lingual and mesial edges are slightly convex, almost similar in length. The occlusal surface is covered with small pits of regular size. MACN-PV RN 1079 resembles the specimens of "Ceratodus" from the Bajo de Santa Rosa and other localities figured by Wichmann (1927: Plate I), the specimen of "Ceratodus" iheringi from the Los Alamitos Formation figured by Cione (1987), and one specimen of "Ceratodus" sp. from the Coli Toro Formation figured by Pascual and Bondesio (1976: Plate I 5).

The specimens catalogued as MACN-PV RN 1080 have five crests (Fig. 2H). The second and third are the largest, being the second slightly more developed. The fourth and fifth crests are situated close one to another. The occlusal surface bears small pits. These materials are similar to the tooth plate figured by Wichmann (1927: Plate III-12) from the Bajo de los Menucos (Río Negro), and from Parri-Aiken (Santa Cruz) of possible Coniacian age figured by Pascual and Bondesio (1976: Plate 1-4).

Comments. Wichmann (1927) published several tooth plates and vertebral remains of "Ceratodus" from Bajo de Santa Rosa and other localities of Río Negro Province. Ceratodontiform lungfishes were widespread around the world dur. ing the Cretaceous (e.g., Ameghino, 1899; Woodward, 1906; Priem, 1924; Arambourg \& Joleaud, 1943; Martin, 1982; Kemp, 1983; Schultze, 1991a;
Martin et al., 1999) and they are abundant in the Late Cretaceous fossil record of Argentina (e,g., Ameghino, 1899; Wichmann, 1924, 1927; Pascual \& Bondesio, 1976; Cione, 1987; González Riga, 1999). The oldest occurrence of this group in South America comes from the Jurassic of Brazil (Brejo Santo Formation; Silva \& Azevedo, 1992) and Uruguay (Tacuarembó Formation; Silva, 1990; Mones, 1997). The taxonomy of the abundant isolated tooth plates discovered in Argentina is not yet resolved, being "Ceratodus" iheringi the only formally known species. Several points of view concerning the systematics of this taxon have been expressed by different authors, but a general agreement has not yet been established (e.g., Martin, 1982; Cione, 1987; Kemp, 1997), therefore we refer to these remains as gen. et sp. indet.

\section{CHONDRICHTHYANS}

Freshwater chondrichthyan remains are known in several Late Cretaceous localities of Argentina, Bolivia, Chile, Peru, and Brazil (e.g., Arratia \& Cione, 1996; González Riga, 19996). These records include Rajiformes and Myliobatiformes (e.g., Arratia \& Cione, 1996). At the Bajo de Santa Rosa locality, only isolated vertebral centra of chondrichthyans have been recognized.

\section{Chondrichthyes Huxley, 1880 incertae sedis}

(Fig. 2J)

Referred Material. MACN-PV RN 1076: eleven complete vertebral centra.

Description. Many isolated amphicoelous centra of chondrichthyes have been found (Fig. 2J); these range in diameter from 6 to $16 \mathrm{~mm}$. The neural and hemal processes are not preserved.

Comments. Similar vertebrae were described from the Los Alamitos Formation (Cione, 1987) and referred to Batoidea, based on studies and comparisons of thin sections of these bones. In addition, many isolated teeth of Batoidea also were found in Los Alamitos locality (personal observation) that is congruent with the previous assignation. Due to the lack of preparation of thin sections on the vertebrae from Bajo de Santa Rosa, as well as the preservation of any other fossil elements that could help in the family identification we tentatively consider these remains as Chondrichthyes incertae sedis.

\section{ANURANS}

In the Cretaceous of South America, anurans are represented by at least two distinctive groups, 
the ancient Pipoidea and the neobatrachian Leptodactylidae.

The earliest pipoid frog is Avitabatrachus uliana from the Early Cenomanian Candeleros Formation of Río Negro Province (Báez et al., 2000). Late Cretaceous Pipidae from South America includes Saltenia ibanezi from the Campanian Las Curtiembres Formation of Salta Province (Reig, 1959; Báez, 1981), and the indeterminate frog specimens from the CampanianMaastrichtian Los Alamitos Formation (Báez, 1987). This family of freshwater frogs is relatively well documented in the Paleogene and Neogene of South America (e.g., Estes, 1975; Baez \& Trueb, 1997; Báez \& Pugener, 1998, 2003). Non South American records of Pipoidea are found in Africa and range from the Early Cretaceous to the present (e.g., Estes, 1977; Tisley et al., 1996; Kobel et al., 1996; Báez, 1996), and an isolated record from the Oligocene of Yemen (Arabian Peninsula; Henrici \& Báez, 2001). The living Pipidae includes Xenopodinae (Xenopus and Silurana genera), and Pipinae Hymenochirini that inhabits northern Africa, and the genus Pipa (Pipinae) that inhabits the tropical regions of northern South America. The fossil record sug. gests a Gondwanan origin for the Pipoidea; the earliest diversification of the extant groups possibly began during the Cretaceous in Africa and South America (e.g., Báez, 1996).

The Leptodactylidae are a paraphyletic assemblage of neobatrachian frogs (we use this familiar name until a revision of the taxonomy of the group is undertaken) that inhabit terrestrial or aquatic environments (e.g., Lynch, 1971; Duellman \& Trueb, 1986; Ford \& Cannatella, 1993). They are recorded in the Los Alamitos (represented by an unnamed taxon closely related to the living telmatobine Caudiverbera; Báez, 1987) and possibly Loncoche formations (González Riga, 1999) of Argentina; and in the Marilia Formation of Brazil (the ceratophryne Baurubatrachus pricei; Báez \& Perí, 1989). The Leptodactylidae were diverse and are relatively well documented in the Paleogene and Neogene fossil record of South America (e.g., Schaeffer, 1949; Casamiquela, 1958; Sigé, 1968; Báez, 1977, 1991, 1996; Bonaparte et al., 1993).

Anura Rafinesque, 1815

Pipoidea Bonaparte, 1831

Pipidae Bonaparte, 1831 Gen.et sp. indet.

(Figs. 3A-B)

Referred Material. MACN-PV RN 1064: sphenethmoid (Fig. 3A); MACN-PV RN 1065: sphenethmoid (Fig. 3B).
Description. The sphenethmoids probably correspond to the same species based on the shared morphology and the approximate similar size. The sphenethmoids are arrow-shaped, dorso-ventrally flat, with two large external narial openings (Figs $3 \mathrm{~A}, \mathrm{~B})$. The orbitonasal foramina are located at the anterior half of the sphenethmoid, below a distinctive dorso-lateral shelf. The frontoparietal fenestra opens in dorsal view; it is wider than in the Paleocene pipid Shelania (Báez \& Trueb, 1997). The frontoparietal fenestra is anteriorly surrounded by the sphenethmoid, a plesiomorphic trait also present in non-xenopodines and nonpipine pipids (Báez \& Pugener, 2003). The nasal septum is visible on the anterior margin of the fenestra. In ventral view, a small fragment of the parasphenoid with the anterior end broken off is observable in MACN-PV RN 1065 (Fig. 3B); the specimen MACN-PV 1064 has a shallow depres. sion that extends anteriorly for the support of the cultriform process of the parasphenoid (Fig. 3A). In both specimens, the anterior border of this depression is not clear, and a surface for the vomer is not observed. The optic foramen is only preserved on the left side in MACN-PV RN 1064 and is fully enclosed by the sphenethmoid.

Comments. The optic foramen enclosed by the sphenethmoid supports the familiar assignation because it is considered a synapomorphy of the Pipidae (Cannatella \& Trueb 1988; Báez \& Trueb, 1997; Báez \& Púgener, 1998), and for that reason both specimens are assigned to this family. The absence of the vomer could also support pipine affinities (e.g., Báez \& Púgener, 1998), but as the specimens of Bajo de Santa Rosa are poorly preserved, we prefer to avoid this feature in our identification.

$$
\begin{gathered}
\text { Neobatrachia Reig, } 1958 \\
\text { Leptodactylidae Berg, } 1838 \\
\text { Gen. et sp. indet. }
\end{gathered}
$$$$
\text { (Figs. 3C-E) }
$$

Referred Materials. MACN-PV RN 1063: fragment of right maxilla (Fig. 3C); MACN-PV RN 1069: twenty three fragments of ornamented cranial bones including incomplete maxillae, and frontoparietals (Fig. 3D); MACN-PV RN 1066: right humerus lacking proximal end (Fig. 3E).

Description. The fragment of the right maxilla and the remaining cranial bones are assigned to this family due to the strongly ornamented external surfaces. The exostosed cranial roof bones are covered with deep subcircular pits of diverse size (Figs $3 \mathrm{C}, \mathrm{D}$ ); the ornamentation in the maxilla decreases near the alveolar border. This type of ornamentation is widely reported in 
fossil Leptodactylidae such as Baurubatrachus pricei (Báez \& Perí, 1989) and Caudiverbera casamayorensis (Schaeffer, 1949; Báez, 1977). On the medial aspect of the maxilla, there are high and narrow alveoli; the teeth were not preserved (Fig. 3C). The assignation is based upon comparison with the material described from the Los Alamitos Formation (Báez, 1987), Baurubatrachus pricei (Báez \& Perí, 1989), and Cenozoic leptodactylids (e.g., Schaeffer, 1949; Báez, 1977; Casamiquela, 1958), which have the same type of ornamentation.

The right humerus (Fig, $3 \mathrm{E}$ ) is lacking the proximal end, and most of the deltopectoral crest has been broken off. The shaft is transversely narrow and dorso-ventrally wide. The medial and lateral edges diverge distally. The eminentia capitata is prominent, similar to that seen in the Los Alamitos leptodactylids (Báez, 1987), but less developed than in the known Paleocene leptodactylids (i.e., taxa from "Banco Negro Inferior" of the Salamanca Formation, Punta Peligro, Chubut, Bonaparte et al., 1993; and Estesiella boliviensis from Bolivia, Báez, 1991, 1995). The medial epicondyle is more prominent than the lateral one, ventrally projected as a blunt crest, and with a distal notch that separates the epicondyle from the eminentia capitata. Similar features are present in Estesiella (Báez, 1991, 1995) and the Punta Peligro leptodactylids (Bonaparte et al., 1993). Overall comparisons suggest greater resemblances with the humeral morphology of the $\mathrm{Pa}$ leocene Leptodactylidae from Punta Peligro than the Late Cretaceous Leptodactylidae from Los Alamitos. It is worthy mentioning that humeral features in anurans are not adequately studied and the assignation of this bone to Leptodactylidae is not strongly supported.

\section{Anura Rafinesque, 1815 incertae sedis (Figs. 3F-G)}

Referred Material. MACN-PV RN 1067: five incomplete vertebrae; MACN-PV RN 1068: five incomplete angulosplenials (Fig. 3F); MACN-PV RN 1070: fused radio and ulna (Fig. 3G).

Description. The specimen figured (MACN.PV RN 1068; Fig. 3F) corresponds to a right angulosplenial of medium size. The coronoid process is medially projected and has a semicircular shape. The groove for the dentary is deep, faces ventro-laterally, and extends posteriorly to the coronoid process. The area for articulation with the skull is not preserved in any of these bones.

The left fused radius and ulna (Fig. $3 \mathrm{G}$ ) has a prominent olecranon process and a neck in the proximal region of the shaft. The distal end is wide and the epiphysis is mainly ossified on the radius. The vertebral remains consist of poorly preserved bodies and fragmentary neural arches, therefore they are not figured neither compared.

Comments. No autapomorphies for family determination could be recognized in these specimens, so they are regarded as Anura incertae sedis. It is worth mentioning that in the Pipidae, the coronoid process is blade-shaped (Báez \& Púgener, 1998), therefore the angulosplenials described should correspond to a non-pipid anuran, possibly to the Leptodactylidae.

\section{TURTLES}

The major groups of Testudines, the Cryptodira and Pleurodira, have been documented in the continental Cretaceous beds of Patagonia (e.g., Broin \& de la Fuente, 1993; de la Fuente et al., 2001; Lapparent de Broin \& de la Fuente, 2001).

The Cryptodira is a very large group of fossil and extant turtles widespread around the world. Among them, the Meiolanidae is the only group recovered in the Cretaceous of South America. The Meiolanidae are medium to large bodied-sized fully terrestrials turtles. This family has heavy shells, a tail club, frills, and cra" nial horns (e.g., Ameghino, 1899; Gaffney, 1983, 1996). Meiolanid turtles were found in the Late Cretaceous Los Alamitos (Broin, 1987) and La Colonia (Gasparini \& de la Fuente, 2000) formations.

The Pleurodira is known by members of the Southern Gondwanan family Chelidae (Broin \& de la Fuente, 1993); Podocnemidoidea pelomedusoids from the Portezuelo and Anacleto formations (de la Fuente, 1993, 2003), and the well preserved Podocneminae specimens from the El Molino (Bolivia; Broin, 1991) and Adamantina (Brazil; Staesche, 1937) formations. In addition, the Araripemydidae family is known from the Albian Santana Formation of Brazil (Meylan, 1996),

The Chelidae includes small to large, fresh water side-necked turtles, known since the Early Cretaceous to the present (e.g., Broin, 1987; Broin $\&$ de la Fuente, 1993; Lapparent de Broin et al., 1997; Lapparent de Broin \& de la Fuente, 2001; de la Fuente et al., 2001; de la Fuente, 2003). The oldest record of Chelidae comes from the Lohan Cura and Candeleros formations (Early AlbianCenomanian) from Neuquén Province, Argentina (de la Fuente, 2003).

Isolated remains of turtles from Bajo de Santa Rosa were first figured by Whichmann (1927); here we report many isolated and frag- 


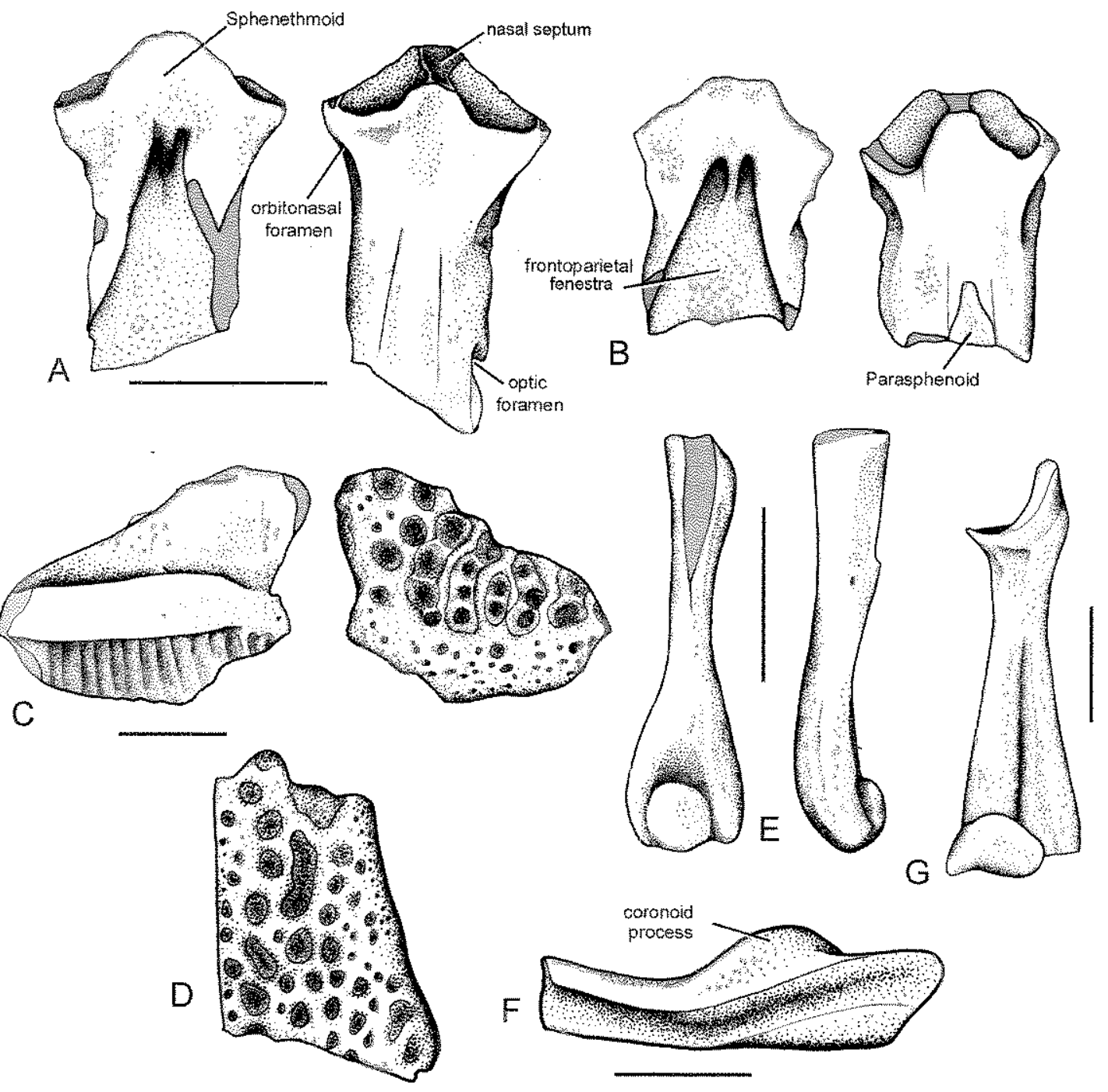

Fig. 3. Anurans. A. MACN-PV RN 1064, sphenethmoid of Pipidae indet. in dorsal and ventral views; B. MACN-PV RN 1065, sphenethmoid of Pipidae indet, in dorsal and ventral views; C. MACN-PV RN 1063, fragment of maxilla of Leptodactylidae indet, in lingual and labial views; D. MACN.PV RN 1069, frontoparietal of Leptodactylidae indet. in dorsal view; E. MACN-PV RN 1066, left humerus of Leptodactylidae indet. in ventral and medial views; F. MACN-PV RN 1068, right angulosplenial of Anura indet. in ventral view; G. MACN.PV 1070, right fused radio and ulna of Anura indet. in posterior view. Scale bar represents $5 \mathrm{~mm}$. Grey pattern indicates broken areas.

mentary shells and postcranial remains collected in the same locality. The ornamentation of the shells is very similar to that reported in other Chelidae (e.g., Broin, 1987; Gasparini \& de la Fuente, 2000). Fragments of xiphiplastrons show the suture for the pelvis as it occurs in all Pleurodires (e.g., Broin, 1987; Lapparent de Broin $\&$ de la Fuente, 2001). The available specimens are extremely fragmentary and do not allow the recognition of the synapomorphies of the chelids; however, at least three different types of caparaces (gen.et sp. indet. 1, 2, and 3) have been recognized on the basis of their size and external ornamentation. Better-preserved turtle specimens from the Allen Formation are currently under study (de la Fuente, personal communication). 


\author{
Chelonii Brongniart, 1800 \\ Pleurodira Cope, 1868 \\ Chelidae Gray, 1825 \\ Gen. et sp. indet. 1
}

(Fig. 4A)

Referred Material. MACN-PV RN 1089: isolated fragments of posterior peripheral caparace.

Description. These specimens correspond to the largest unnamed turtle from the Bajo de Santa Rosa locality (Fig. 4A). The ornamentation is slight, with irregular polygons and dichotomized furrows.

Comments. This type of shell ornamentation is also known in the chelids of the Los Alamitos and La Colonia formations (Broin, 1987; Gasparini \& de la Fuente, 2000), as well as in the large specimens of Chelidae from the Early Paleocene of Punta Peligro (Chubut, Argentina; e.g., Bona et al., 1998).

\section{Gen.et sp. indet. 2}

(Figs. 4B-C)

Referred Material. MACN.PV RN 1090: iso* lated fragments of shell.

Description. These specimens correspond to a small to medium sized turtle with a heavy or. namented carapace (Figs. $4 \mathrm{~B}, \mathrm{C}$ ). The plates are thick and bear deep irregular elongated polygons on the external surface. The fragment of xiphiplastron shows the suture for the pelvis (Fig. $4 \mathrm{~B})$, which is considered an autapomorphy of pleurodires (e.g., Broin, 1987; Lapparent de Broin $\&$ de la Fuente, 2001 ).

Comments. A similar pattern of ornamentation is observed in some specimens from the Los Alamitos (Broin, 1987), Loncoche (González Riga, 1999), and La Colonia formations (Gasparini \& de la Fuente, 2000).

\section{Gen. et sp. indet. 3}

(Fig. 4D)

Referred Material. MACN-PV RN 109: isolated fragments of shell.

Description. The materials belong to the smallest turtle specimen collected at Bajo de Santa Rosa. The plates are thin and lack macroornamentation (Fig. 4D).

Comments. This type of shell was reported in the Los Alamitos (Broin, 1987) and La Colonia (Gasparini \& de la Fuente, 2000) formations. This specimen could be tentativelly referred to the Phrynops group; the size and the external surface of the shells resemble Bonapartemys bajobarrealis (from the Turonian-Campanian Bajo Barreal Formation) and Palaeophrynops patagonicus (from the Los Alamitos Formation; Lapparent de Broin \& de la Fuente, 2001). Nevertheless, based on the fragmentary nature of the specimens we tentatively consider them as Chelidae indet.

\section{PLESIOSAURS}

Most of the available fossil remains of plesiosaurs in the Cretaceous of South America are poor and fragmentary (Gasparini \& Goni, 1985; Gasparini et al., 2001); the exceptions are few fairly complete specimens from Chile and Patagonia, Argentina (e.g., Casamiquela, 1969; Gasparini \& de la Fuente, 2000; Gasparini et al., $2003 a \& b)$. In outcrops of the Allen Formation, three incomplete specimens of Elasmosauridae have been previously described (Gasparini \& Salgado, 2000). The Elasmosauridae is a family of long necked plesiosaurs found widespread around the world during the Cretaceous; nevertheless, their fossil record is more diverse and abundant in North America (e.g., Williston, 1903, 1906; Welles, 1952). Elasmosaurid remains were also reported in the Lajas (Callovian; $c f$. Muraenosaurus; Gasparini \& Spalleti, 1993), Agrio (Valanginian-Hauterivian; Lazo \& Cichowolski, 2003), Loncoche (González Riga, 1999), and Jaguel (Gasparini et al., 2003b) formations.

$$
\begin{gathered}
\text { Sauropterygia Owen, } 1860 \\
\text { Plesiosauria De Blainville, } 1835 \\
\text { Elasmosauridae Cope, } 1869 \\
\text { Gen. et sp. indet. }
\end{gathered}
$$$$
\text { (Fig. 4E) }
$$

Referred Material. MACN-PV RN 1087: three cervical centra, one caudal centrum, and fragmentary remains.

Description. All the collected specimens are isolated elements; the size varies among them suggesting that these elements correspond to different individuals. The cervical centra have facets for the articulation of the singlemeaded ribs; they are latero-ventrally oriented (Fig. 4E) rather than laterally oriented as seen in the dor. sal and caudal vertebrae. The centrum is dorsoventrally low, antero-posteriorly short, transversely wide, and slightly amphicoelous. Both anterior and posterior articular surfaces are kidney-shaped. On the ventral surface two large foramina are present.

The caudal centrum is badly preserved; it is dorso-ventrally low, antero-posteriorly short, and transversely wide. The articular surface for the rib is oval and laterally projected. 

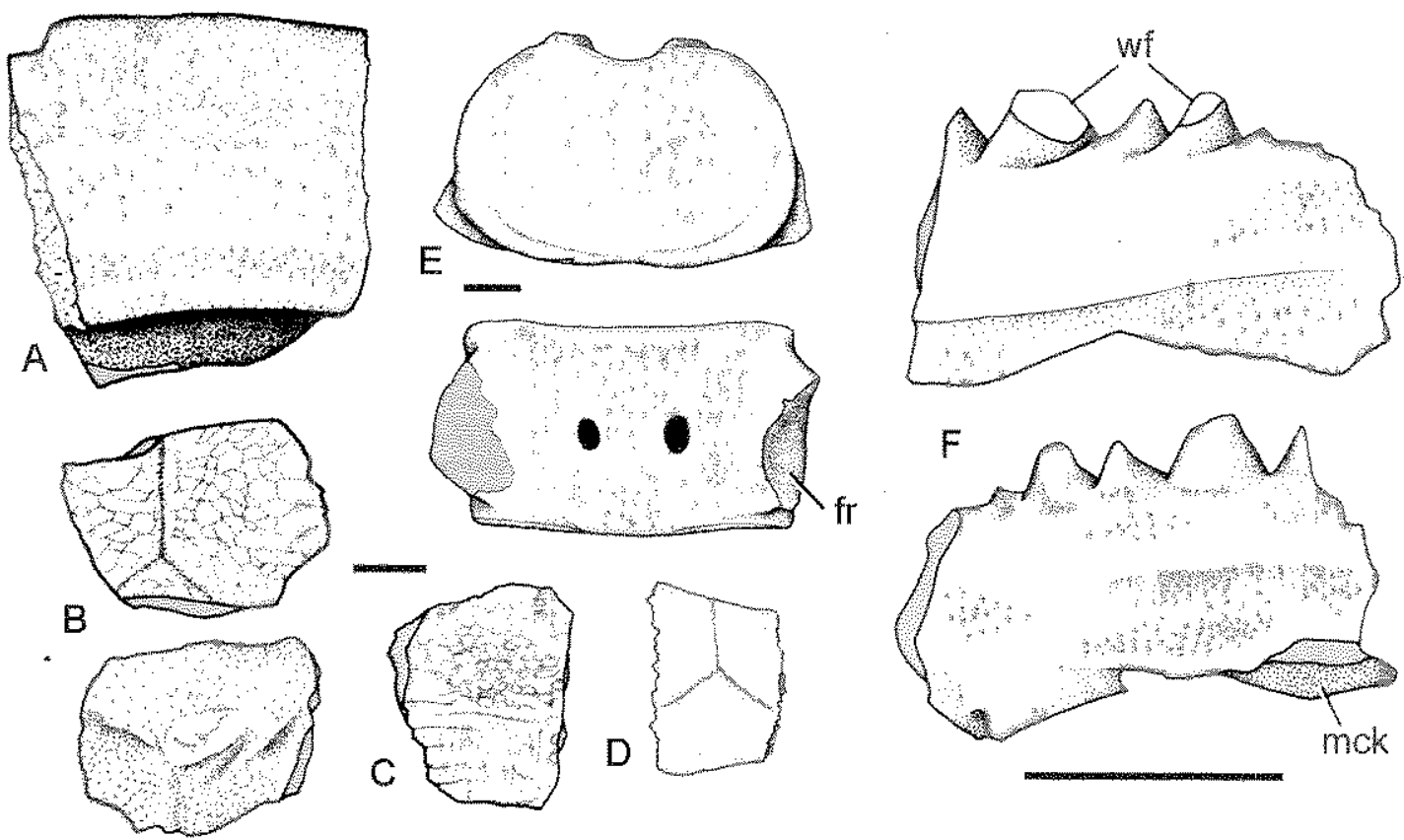

Fig. 4. Turtles. A. MACN-PV RN 1089, posterior peripheral plate of Chelidae gen. et sp. indet. 1; B. MACN-PV RN 1090, xiphiplastron of Chelidae gen. et sp. indet. 2 in external and internal views; C. MACN-PV RN 1090, pleural plate of Chelidae gen. et sp. indet. 2; D. MACN -PV RN 1091, peripheral plate of Chelidae gen. et sp. indet. 3. Plesiosaurs. E. MACN-PV RN 1087, cervical centrum of Elasmosauridae indet. in anterior and ventral views. Sphenodonts. F. MACN-PV RN 1062, fragment of right dentary of Sphenodontia indet. in labial and lingual views. Scale bar represents $10 \mathrm{~mm}$ in A$\mathrm{E}$ and $5 \mathrm{~mm}$ in $\mathrm{F}$. Grey pattern indicates broken areas. Abbreviations: fr, facet for $\mathrm{rb}$; mck, meckelian groove; wf, wear facet.

Comments. Rather complete specimens of elasmosaurids from the middle section of the Allen Formation near the Lago Pellegrini (Río Negro Province) were described by Gasparini \& Salgado (2000). These specimens were considered closely related to Elasmosaurus platyurus, a typical long-neck plesiosaur of North America ("Western Interior Sea"; Welles, 1943) (Gasparini \& Salgado, 2000; Gasparini et al., 2001). Other elasmosaurids from northern Río Negro Province were discovered in beds of the Jagüel Formation (Late Maastrichtian) and referred to $\mathrm{cf}$. Mauisaurus sp. and Tuarangisaurus? cabazai (Gasparini et al., 2003b).

\section{SPHENODONTS}

Until recently discoveries of abundant re. mains in the Late Triassic of Brazil (Ferigolo, 2000; Bonaparte, personal communication) and lower Late Cretaceous of Argentina (Simón \& Kellner, 2003; Apesteguía \& Novas, 2003), sphenodontids had been a rare component of the Mesozoic vertebrate assemblages in South America. In contrast, this group is relatively well documented in the Late Triassic to Cretaceous beds of North America, Mexico, Europe, China, Africa, and India (e.g., Sues et al., 1994; Reynoso, 1997; Fraser \& Benton, 1989; Wu, 1994; Sues \& Reisz, 1995; Evans et al., 2001).

Lepidosauria Haeckel, 1866

Rhynchocephalia Günther 1867 (sensu

Gauthier et al, 1988)

Sphenodonta Williston, 1925

Sphenodontidae Cope, 1870 (sensu Reynoso, 1996)

Gen.et sp. indet.

(Fig, 4F)

Referred Material. MACN-PV RN 1062; a middle portion of the right lower jaw.

Description. Despite its fragmentary condition, the portion of the dentary preserved indi- 
cates the presence of sphenodonts in the Allen Formation at Bajo de Santa Rosa. The dentary (Fig. 4F) is high and bears a longitudinal depresw sion on its labial surface. The teeth are fully acrodont with flanges (synapomorphic features shared by this specimen and the crown-group sphenodonts; Sues et al., 1994). The teeth are lingually placed and slightly transversely flattened with the main axis mesiolingual-distolabially oriented. The distal edge imbricates slightly labially towards the posterior tooth, as in other sphenodonts (e.g., Tingitana anouolae from the Early Cretaceous of Morocco; Evans \& Sigogneau-Russel, 1997). The posterior teeth are larger than the anterior ones. Wear facets are present on the tip of the two tallest teeth. The presence of well established wear facets on the teeth is a feature share with Sphenodontidae (e.g., Reynoso, 2000).

Comments. This specimen represents the first record of Campanian-Maastrichtian sphenodonts in South America, and possibly indicates the persistence of a gondwanan lineage of Clevosauruslike sphenodonts yet poorly known in the Jurassic and Cretaceous beds of South America. Kaikaifilusaurus calvoi (Simón \& Keliner, 2003) and Priosphenodon avelasi (Apesteguía \& Novas 2003 ; probably a junior synonymous of $K$. calvoi) both from the Cenomanian Candeleros Forman tion (Neuquén and Río Negro) are Eilenodontinae sphenodonts; they are characterized by the presence of a deep dentary and transversely wide teeth (Simón \& Kellner, 2003; Apesteguía $\&$ Novas, 2003), features clearly different from the specimen from Bajo de Santa Rosa.

\section{OPHIDIANS}

The ophidians are represented in the Cretaceous of South America by at least two families: Dinilysiidae, including Dinilysia patagonica (e.g., Woodward, 1901; Bonaparte, 1991; Caldwell \& Albino, 2002) from the Bajo de la Carpa Formation (Coniacian-Santonian; Heredia \& Salgado, 1999), and Madtsoiidae, including Alamitophis argentinus (Albino, 1986, 1987), A. elongatus (Albino, 1994), Patagoniophis parvus (Albino, 1986, 1987), Rionegrophis madtsoioides (Albino, 1986,1987 ) from the Los Alamitos Formation, and an unnamed species from the El Molino Formation (Bolivia; Gayet et al., 2001). Alamitophis argentinus was also recovered in the La Colonia Formation (Albino, 2000), and A. sp. cf. A. argentinus and Patagoniophis sp. cf. P. parvus were recognized in the Early Eocene of Australia (Scanlon, 1993). Indeterminate isolated remains probably assigned to Madtsoiidae have also been documented in the Loncoche (Gonzalez Riga, 1999), La Colonia (Albino, 2000), and Los Alamitos formations (personal observation).

The Boidae is a group of macrostomatan snakes constituted by Boinae, Pythoninae, Erycinae, and Calabariinae subfamilies (sensu Rage, 2001); which are doubtfully documented in the Cretaceous of South America. Members of Boidea were tentatively identified in the Los Alamitos (considered as probable Erycinae and Boinae; Albino 1990, 1996) and La Colonia formations (Albino, 2000). These remains are poorly preserved and tentatively placed in this family (Albino, 1990, 2000); therefore, the occurrence of Boidea during this timeframe is not yet clearly demonstrated.

The Madtsoildae have been recovered in South America (Campanian-Maastrichtian to Eocene), Africa and Madagascar (Cenomanian to Eocene), Australia (Eocene to Pleistocene), India (Maastrichtian) (e.g., Hoffstetter, 1961; Albino, 1996; Rage, 1987, 1998; Scanlon, 1992, 1993; Scalon \& Lee, 2000; Gayet et al, 2001), Spain (Maastrichtian; Astibia et al., 1990; Rage, 1996, 1999), and France (Sigé et al., 1997). The monophyly and phylogenetic relationships of the Madtsoiidae among Serpentes are not well established yet (e.g., Scanlon \& Lee, 2000; Rieppel et al., 2002). Recent phylogenetic analyses place Madtsoiidae (with the Australian genus Wonambi as a representative taxon) among basal snakes (Scanlon \& Lee, 2000), while other interpretations consider that this family has Macrostomata affinities (Rieppel et al., 2002).

Herein, we comment the presence of Alamitophis argentinus Albino, Patagoniophis parvus Albino, undetermined madtsoiid remains, and a medium-size ?madtsoiid trunk vertebra, which in our view belongs to a new taxon. In addition, preparation and observation of a new trunk vertebra of Rionegrophis madtsoioides Albino from Los Alamitos supports its Madtsoiidae affinities, as was initially interpreted (Albino, 1986).

Serpentes Linnaeus, 1758

Madtsoiidae Hoffstetter, 1961

Patagoniophis parvus Albino, 1986

(Fig. 5A)

Referred Material. MACN-PV RN 1049 (Fig. 5A) and MACN-PV RN 1056: incomplete trunk vertebrae.

Description. Two well preserved trunk vertebrae are assigned to Patagoniophis parvus (Fig. 5A). These remains share the diagnostic features of $P$ p parvus (Holotype MACN-PV RN 

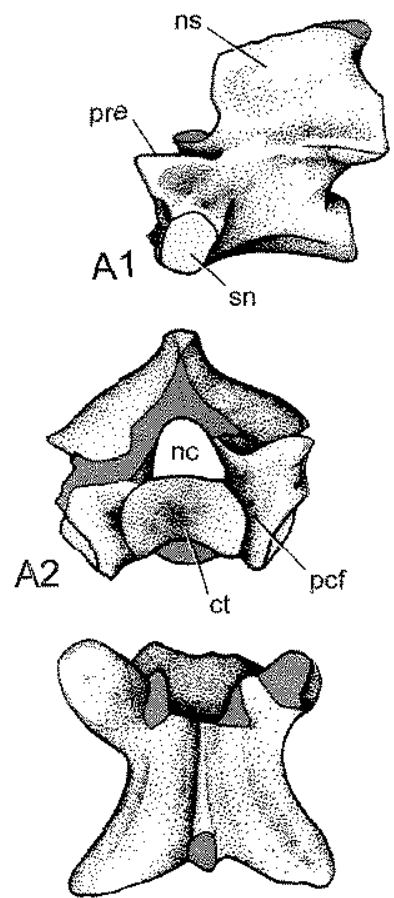

A4

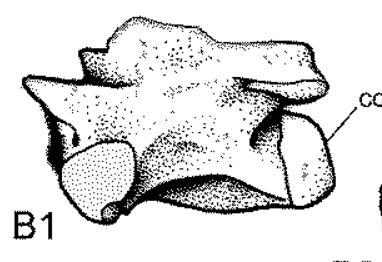

$\mathrm{B} 2$
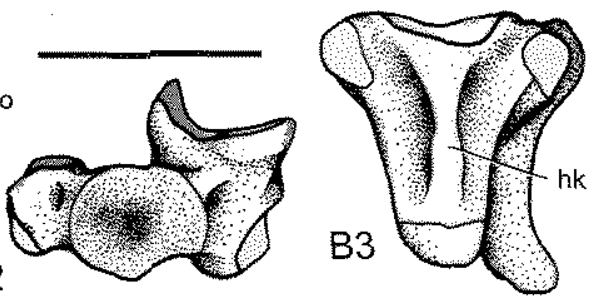
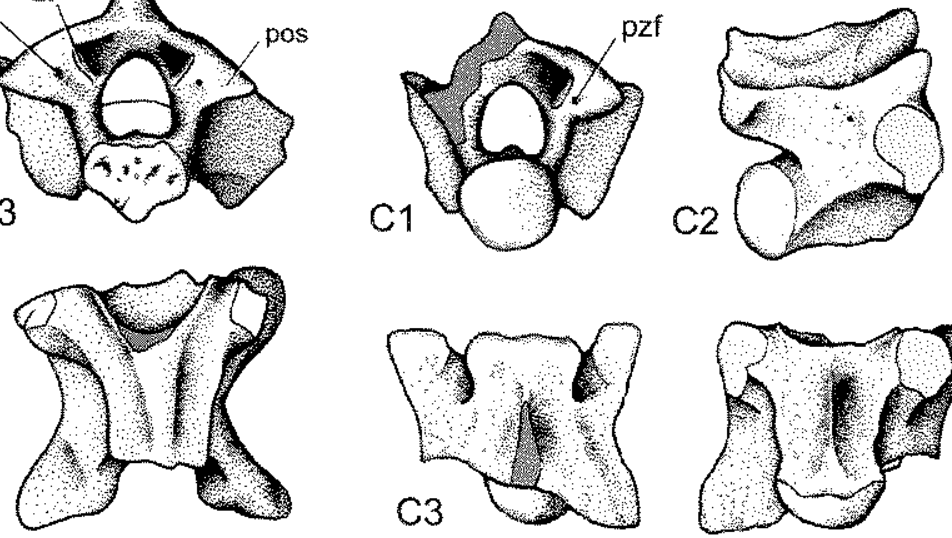

A5
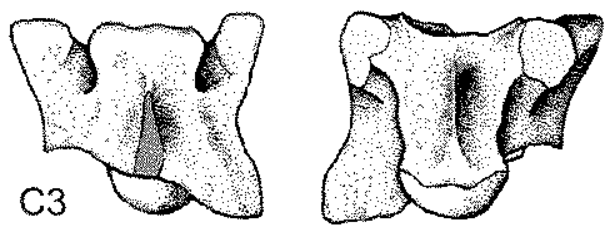

C4

Fig. 5. Snakes. A. MACN-PV RN 1049, trunk vertebra of Patagoniophis parvus Albino in lateral (A1), anterior (A2), posterior (A3), dorsal (A4) and ventral (A5) views; B. MACN-PV RN 1053, trunk vertebra of Alamitophis argentinus Albino in lateral (B1), anterior (B2) and ventral (B3) views; C. MACN-PV RN 1052, trunk vertebra of Madtsoiidae indet. in posterior (C1), lateral (C2), dorsal (C3) and ventral (C4) views. Scale bar represents $5 \mathrm{~mm}$. Grey pattern indicates broken areas. Abbreviations: co, condyle; ct, cotyle; hk, haemal keel; nc, neural canal, ns, neural spine; pcf, paracotylar foramen; pos, postzygapophysis; pre, prezygapophysis; pzf, parazygantral foramen; sn, synapophysis; zf, zygosphene; zt, zygantrum.

33; Albino, 1986), including very small vertebrae each possessing a narrow centrum, shallow haemal keel, and low and thin neural spine (Albino, 1986). The zygantrum is deep, with the dorsal edge slightly convex; this structure is not preserved in the holotype specimen.

Comments. Up to now, this smallest species of madtsoiid was recognized in the Los Alamitos Formation (Albino, 1986, 1987), and in the Early Eocene of Australia (Scanlon, 1993). The new record in the Bajo de Santa Rosa locality expands the temporal and geographic distribution of this species during the Cretaceous.

Madtsoiidae Hoffstetter, 1961 Alamitophis argentinus Albino, 1986 (Fig. 5B)

Referred material. MACN-PV RN 1053: incomplete trunk vertebra.
Description. Only an incomplete vertebra could be assigned tentatively to $A$. argentinus (Fig. 5B). This specimen has only the centrum and part of the left portion of the neural arch preserved. The specimen from Bajo de Santa Rosa shares with the holotype of $A$, argentinus (Holotype MACN-PV RN 27; Albino, 1986) a similar morphology of the vertebral centrum, including a narrow and not very triangular in shape, with a thick haemal keel separating deep lateral depressions. This material is slightly smaller than the holotype of A. argentinus (MACN-PV RN 33).

Comments. Alamitophis (Albino, 1986) is widely documented in the Los Alamitos, Allen, and $\mathrm{La}$ Colonia formations, as well as in the Early Eocene of Australia (Albino, 1994, 2000; Scanlon, 1993). If the taxonomic identifications of these records (only based on vertebral isolated remains) are correct, this species has a broad temporal and geographic distribution in Gondwana. 
As a preliminar comment, Alamitophis seems to be the predominat snake in the Los Alamitos, Allen, and La Colonia formations.

\section{Madtsoiidae Hoffstetter, 1961 \\ Gen. et sp. indet.}

(Fig. 5C)

Referred Material. MACN-PV RN 1051, MACN-PV RN 1052 (Fig. 5C), MACN-PV RN 1054: isolated trunk vertebrae.

Description. MACN-PV RN 1052 (Fig. 5C) is the most complete vertebra from Bajo de Santa Rosa that is referred to this family. This vertebra has a parazygantral foramen which is a unique vertebral synapomorphy of Madtsoiidae (Rage, 1998). This specimen is a little larger than Patagoniophis parvus and smaller than Alamitophis argentinus. The vertebra is high and short. The haemal keel is thin and limited later. ally by deep depressions. The neural spine is broken off on its posterior part. The zygantrum is high and deep with the dorsal border slightly concave. The association of these mentioned features in the vertebra from Bajo de Santa Rosa differs significantly from Patagoniophis and Alamitophis making it difficult to assign it to genus level.

MACN-PV RN 1051 (not figured) corresponds to a caudal vertebra due to the presence of a pair of pedicels for the chevrons near the posterior end of the centrum, and long narrow transverse processes antero-laterally projected.

\section{?Madtsoiidae Hoffstetter, 1961 Gen. et sp. indet.}

(Fig. 6)

Referred Material. MACN-PV RN 1059: almost complete trunk vertebra.

Description. MACN-PV RN 1059 (Fig. 6) consists of a trunk vertebra lacking both postzygapophyses, the anteriormost part of the prezygapophyses, and the postero-dorsal portion of the neural spine. The vertebra is high and wide. The dorsal edge of the neural spine, although incomplete, seems to be straight. The zygosphene is weak, transversely elongate, and low. The prezygapophyses are antero-laterally projected and apparently do not have a prezygapophyseal process on the right side where the prezygapophysis is better preserved. Only one large paracotylar foramen is present on each side. The centrum is dorso-ventrally compressed and triangular in ventral view, more elongate antero-posteriorly than transversely wide, with a prominent haemal keel and lateral depressed areas. The zygantrum is moderately deep, connecting both depressions by a shallow transversal groove. The area of the parazygantral foramina and the postzygapophyses has been broken off. The condyle is oval shaped and faces postero dorsally.

This specimen is larger than Alamitophis argentinus and A, elongatus (Albino, 1986, 1987, 1994) and differs from these two species in having the vertebral centrum wide and short, shallow depressions on both sides of the haemal keel, shallow zygantrum with a transversal groove connecting both, and a thicker neural arch. This taxon from Bajo de Santa Rosa differs from Rionegrophis madtsoioides, the largest madtsoild snake from Los Alamitos (Albino, 1986, 1987), in having a narrow and long centrum, a very low and wide zigosphene, only one large paracotylar foramen, and a well developed haemal keel. This possible madtsoiid differs from Dinilysia patagonica (Woodward, 1901; Rage \& Albino, 1989) in having the zygosphene transversely large and low, and a slender neural arch. In addition, this specimen differs from Boidae snakes in the proportion of the centrum and in the lack of prezygapophysial processes.

Comments. The specimen here described represents the largest snake recovered from the Bajo de Santa Rosa locality. The familiar status of this taxon is doubtful due to the lack of the postzygapophyses and part of the zygantrum where the parazygantral foramen should be located. The combination of these features mentioned in this specimen could indicate the presence of a new taxon, but new findings are required in order to support this statement. In addition to this specimen, unpublished vertebrae from the Los Alamitos Formation could be assigned to the same taxon. These specimens are: MACN-PV RN 201, MACNPV RN 219, and MACN-PV RN 220.

Comments of Rionegraphis madtsoioides. An undescribed trunk vertebra (MACN-PV RN 226) of Rionegrophis madtsoioides from the Los Alamitos Formation provides new information about the taxonomic affinities of this species. Albino $(1986,1987)$ tentatively included this taxon in the Madtsoiinae subfamily because one diagnostic feature (i.e., the presence of a parazygantral foramen) was not preserved in the holotype and the only available specimen. MACN-PV RN 226 shares with the holotype of Rionegrophis madtsoioides (MACN-PV RN 32), a similar size, with an antero. posteriorly short and triangular centrum, thick and narrow zygosphene, and paracotylar foramen. This new specimen also possesses a parazygantral foramen supporting Rionegrophis madtsoioides as a member of Madtsoilidae. 

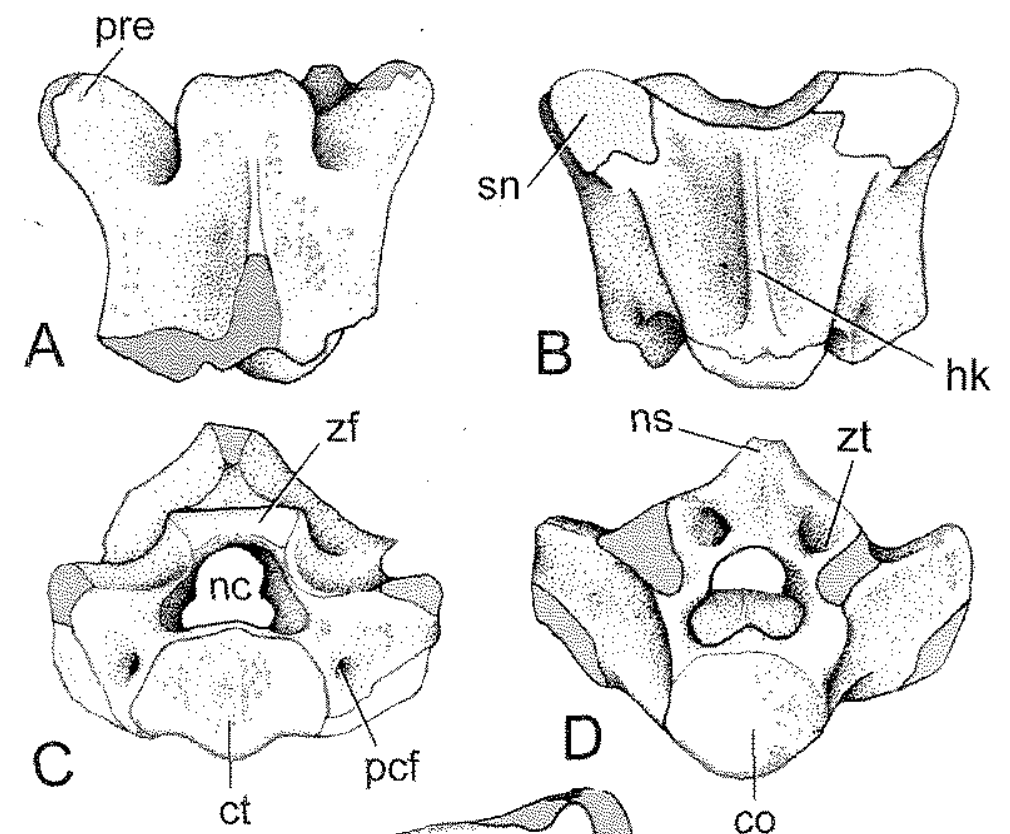

ns

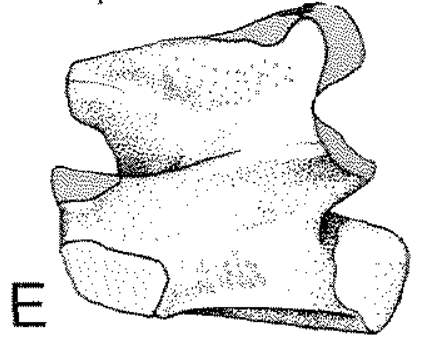<smiles>[3H]C=C[SiH3]</smiles>
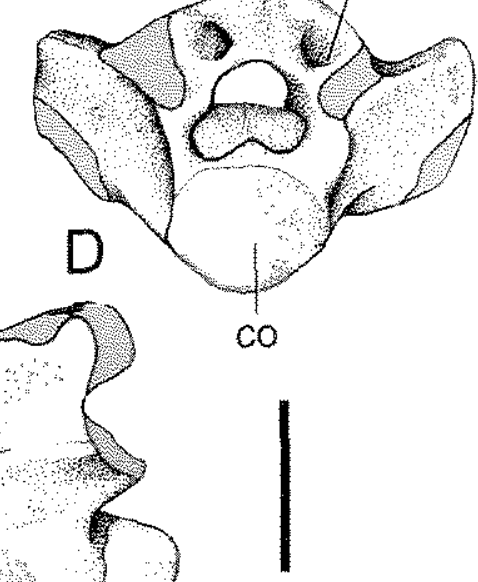

Fig. 6. ?Madtsoiidae MACN-PV RN 1949, trunk vertebra in dorsal (A), ventral (B), anterior (C), posterior (D) and lateral (E) views. Scale bar represents $5 \mathrm{~mm}$. Grey pattern indicates broken areas. Abbreviations as in Fig. 5.

\section{DINOSAURS}

\section{SAUROPODS}

Titanosaur sauropods are widespread in most. of continental Cretaceous beds of the world, but are more abundant and diverse in Gondwana, such as in South America (e.g., Lydekker, 1893; Huene, 1929; Bonaparte \& Gasparini, 1978; Bonaparte \& Powell, 1980; Powell, 1986, 2003; Calvo \& Bonaparte, 1991; Bonaparte \& Coria, 1993; Salgado, 1996; Kellner \& Azevedo, 1999), Africa (Depéret, 1896; Taquet, 1976; Jacobs et al., 1993; Curry Rogers \& Forster, 2001; Smith et al., 2001), and India (e.g., Lydekker, 1877, 1879, 1887; Jain \& Bandyopadhyay, 1997). Outside Gondwana, titanosaurs have been found in North America (e.g,, Gilmore, 1922, 1946; Lucas \& Hunt, 1989), Asia (e.g., Hoffet, 1942; Nowinski, 1971; Borsuk-Byalinicka, 1977;
Kurzanov \& Bannikov, 1983), and Europe (e.g., Lydekker, 1887; Le Loeuff, 1993, 1995; Sanz et al., 1999).

In recent years, the phylogenetic relationships of titanosaurian sauropods have been reviewed by different authors, and the general consensus is that the titanosaurid Saltasaurinae appears to be one of the most derived groups from this lineage (e.g., Salgado et al, 1997a; Upchurch, 1995, 1998; Wilson, 2002).

At the present, the titanosaurid sauropods reported from the Allen Formation are Aeolosaurus sp. (Salgado \& Coria, 1993) and Rocasaurus muniozi (Salgado \& Azpilicueta, 2000). Originally, Neuquensaurus austratis (e.g., Lydekker, 1893; Powell, 2003), Laplatasaurus (= "Titanosaurus") araukanicus (Huene, 1929; Powell, 2003; Wilson \& Upchurch, 2003), and Pellegrinisaurus powelli (Salgado, 1996) were considered as coming from the Allen Formation, 
but recent geological studies consider that these species were collected from the Rio Colorado Subgroup (Heredia \& Salgado, 1999).

A new small saltasaurine titanosaurid, Bonatitan reigi gen. et sp. nov, based on two incomplete specimens is described and compared here. These two specimens were unearthed together from the same site at the Bajo de Santa Rosa locality.

Dinosauria Owen, 1842

Saurischia Seeley, 1888

Sauropoda Marsh, 1878

Titanosauria Bonaparte and Coria, 1993

Titanosauridae Lydekker, 1893 (sensu Salgado, 2003)

Saltasaurinae Powell, 1986 (sensu Sereno, 1998)

Bonatitan Martinelli \& Forasiepi gen. nov. (Figs. 7-17)

Type and only known species. Bonatitan reigi sp. nov.

Diagnosis. Small-sized titanosaurid Saltasaurinae characterized by the following association of characters: 1) longitudinal groove located on the suture between parietals that continues posteriorly over the supraoccipital to the foramen magnun; 2) basisphenoid tubera long and narrow (more than twice long as wide); 3) dorsal to middle caudal vertebrae with deep oval to circular pits on both sides of the prespinal lamina; 4) anterior caudal vertebra with spinopostzygapophysial and spino-prezygapophysial laminae; 5) neural arch of anterior caudals with deep interzygapophysial fossae with numerous pits; 6) anterior caudal vertebra with an acces. sory sub-horizontal lamina extending from the antero-ventral portion of the postzygapophysis to the mid-portion of the spino-prezygapophysial lamina; finally, 7) anterior caudal vertebra with a prominent axial crest on the ventral surface of the cemtrum.

Etymology. The genus is named in honor of Dr. José F. Bonaparte, due to his immense contribution to the knowledge of Mesozoic vertebrates of South America.

Bonatitan reigi Martinelli \& Forasiepi $s p$, nou.

Diagnosis. As for the genus.

Etymology. The species is named in honor to Dr. Osvaldo Reig for his contribution to South American paleontology.

Holotype. MACN-PV RN 821: complete braincase, middle dorsal vertebra, anterior caudal vertebra, middle caudal neural arch, left humerus, fragment of metacarpal, both femora, both tibiae, left fibula, left calcaneous, left metatarsal I, and some fragmentary elements.

Referred Material. MACN-PV RN 1061: complete braincase, incomplete anterior cervical vertebra, left radius, left ulna, left femur, left tibia, calcaneous, metatarsal III, a few incomplete chevrons, and some fragmentary indeterminate elements.

Locality and horizon. Both specimens were collected in the Bajo de Santa Rosa locality, Río Negro Province, Argentina (Fig. 1); Allen Formation, Malargüe Group, Campanian-Maastrichtian (Uliana \& Dellapé, 1981), Late Cretaceous.

\section{Description and Comparisons}

The holotype (MACN-PV RN 821) and the referred specimen (MACN-PV RN 1061) were unearthed in the same paleontological site. The remains were disarticulated and the bones of each individual were mixed. The specimens were segregated on the basis of their relative sizes. MACN-PV RN 821 is selected as holotype because it is more complete and the elements preserved are more diagnostic than the other specimen. The estimation of the body size (mainly based on comparisons of the length between the femora and tibiae) suggest that the holotype specimen (MACN-PV RN 821) is approximately $20 \%$ larger than MACN-PV RN 1061. The description and comparisons are based on both specimens. The measurements of the postcranial bones are given in the appendix.

\section{Braincase}

Dermal bones and Chondrocranium. Two well preserved braincases are available. Most of the chondrocranium is preserved in both specimens of Bajo de Santa Rosa, and it is formed by supraoccipital, exoccipital, basioccipital, basisphenoid, parasphenoid, orbitosphenoid, laterosphenoid, prootic, and opisthotic bones. The only dermal bones preserved are the frontals and parietals. The sutures are clearer in MACN-PV RN 1061 than in MACN-PV RN 821 perhaps in correlation with the smaller size and younger age of the former specimen. For descriptive purposes, the articular surface of the occipital condyle is posteriorly oriented as it occurs in Rapetosaurus krausei, which has one of the better-preserved titanosaur skull (Curry Rogers \& Forster, 2001, 2004).

The frontals (Fig. 7) are antero-posteriorly short; they are not fused in the sagittal plane as observed in most sauropods (e.g., titanosauriforms and diplodocids; Huene, 1929; Berman \& McIn- 

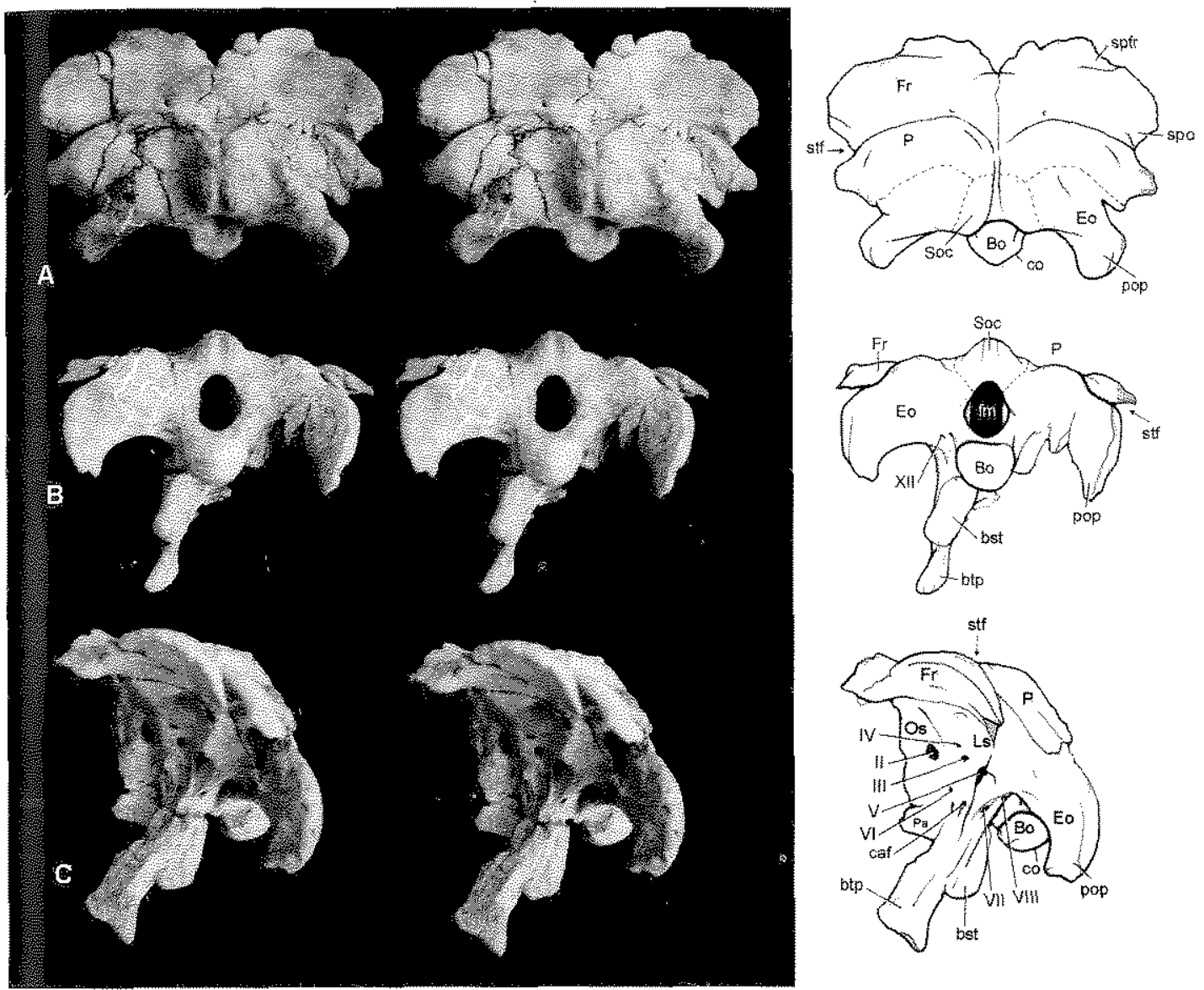

Fig. 7. Bonatitan reigi gen et sp. nov. Holotype MACN-PV RN 821, stereophotographs with accompanying line drawing of the basicranium in dorsal $(A)$, occipital (B) and lateral (C) views. Scale bar represents $50 \mathrm{~mm}$. Abbreviations: Bs, basisphenoid; Bo, basioccipital; bst, basisphenoid tuber; btp, basipterygoid process; ca, crista antotica; caf, carotid foramen; co, occipital condyle; cpr, cresta prootica; Eo, exoccipital; fm, foramen magnum; fo, fenestra oval; $\mathrm{Fr}$, frontal; jv, jugular vein foramen; Ls, laterosphenoid; $\mathrm{mf}$, metotic fissure; Os, orbitosphenoid; P, parietal; pop, paraoccipital process; Ps, parasphenoid; Soc, supraoccipital; spfr, surfaces for the prefrontal; spo, surfaces for the postorbital; stf, supratemporal fossa; I-VIII and XII, cranial nerves foramina.

tosh, 1978); in contrast, they are fused posteriorly with the parietals. The external surface of the frontals faces dorsally and forms the anterior border of the supratemporal fenestra as in other titanosaurids (e.g., Antactosaurus, Rapetosaurus and Saltasaurus; Huene, 1929; Curry Rogers \& Forster, 2001, 2004; Powell, 2003). On the anterior region of the suture between the frontals there is an inverted " $\mathrm{U}$ " shaped tuberosity. On the lateral edge of the frontal there are two articular surfaces: an anterior one for the articulation with the prefrontal and a smaller postero-lateral one for the articulation with the postorbital (the prefrontals and postorbitals are not preserved). On the inner side, the frontals have two concave surfaces divided by a sharp and almost transversal crest. The larg. est ventral surface supports most of the orbithosphenoid and laterosphenoid, and forms the posterior wall of the orbital cavity; the small dorso-medial surface forms the posterior wall of the olfactory tract and supports the region of the orbitosphenoids where the olfactory bulbs lie. Between the dorsal contact of the frontal and orbitosphenoid there is a transversal groove for the anterior cerebral artery (Berman \& McIntosh, 1978).

The parietals (Fig. 7) contribute to the roof of the skull; they are mainly exposed in dorsal view. These bones are relatively wider than in 
Antarctosaurus, but similar to Rapetosaurus. The parietals are shorter antero-posteriorly than the frontals, and slightly concave. The anterior edge of the parietal forms a crest that delimits the posterior border of the supratemporal fenestra. The contact of the parietal with the supraoccipital and exoccipital is not observable. In the sagittal plane; where both parietals contact, there is a tuberosity that continues and enlarges backwards over the supraoccipital. This tuberosity, for attachment of the axial musculature, defines a longitudinal groove that extends from the parietal to the foramen magnum. The groove over the parietals is only observable in Bonatitan.

The parietal fontanelle and post-parietal fontanelle are both absent in Bonatitan as in all known titanosaurs. These openings are only de. veloped in Dicraeosaurus and Amargasaurus (Janensch, 1935-36; Salgado \& Calvo, 1992).

The supraoccipital (Fig. 7) is fused laterally to the exoccipital; based on other sauropods, the supraoccipital may form the dorsal border of the foramen magnum. On the posterior surface the supraoccipital bears a longitudinal groove that reaches the foramen magnum (see also above). This groove is also present in Rapetosaurus (Curry Rogers \& Forster, 2004) but apparently it does not extend anteriorly on the parietal as in Bonatitan. In Anctartosaurus (MACN.PV 6804) the supraoccipital forms a distintive process but a longitudinal groove is not evident (Huene, 1929; contra Curry Rogers \& Forster, 2004). The dorsal edge of the foramen magnum in MACN-PV RN 821 is more concave than in MACN-PV RN 1061.

The supratemporal fenestra (Fig. 7) is ex. tremely short antero-posteriorly and very wide transversely, the anterior edge is convex while the posterior one is slightly concave, and opens on the dorsal surface of the skull. In Camarasaurus (Madsen et al., 1995), Brachiosaurus (Janensch, 1935-36, 1950), Diplodocus (Upchurch, 1999), Rebbachisaurus (Calvo \& Salgado, 1995), and dicraeosaurids (Janensch, 1935-36; Salgado \& Calvo, 1992) the frontals are excluded from the anterior edge of the supratemporal fenestra. In Nemegtosaurus (Nowinski, 1971) the participation of the frontal in the border of the supratemporal fenestra is very reduced.

The basioccipital (Fig. 7) forms the occipital condyle, which is prominent and almost spherical. We follow the interpretation of Rapetosaurus (Curry Roger \& Forster, 2001, 2004) in which the occipital condyle is posteriorly projected rather than postero-ventrally as in Brachiosaurus (Janensch, 1935-36, 1950), or ventrally as in dieraeosaurids and diplodocids (Salgado \& Calvo, 1992; Berman \& McIntosh, 1978).
The basisphenoid forms mainly the basispterygoid processes and a portion of the crista prootica; the sutures among surrounding bones are not observable. The basispterygoid processes of the basisphenoid are long, anteroventrally projected, slender, and less divergent than in Antarctosaurus (in which an angle of almost 90 degrees is formed; Huene, 1929), but more divergent than in Rapetosaurus (Curry Rogers \& Forster, 2004). The basisphenoid tubera (Figs. 7B, C) are elongated and narrow, unfused to each other, and delimit the lower surfaces of the pituitary fossa. The basisphenoid tubera of Bonatitan differ from Antaretosaurus and Rapetasaurus which have dorso-ventrally shorter and transversely wider tubera (Huene, 1929; Curry Rogers \& Forster, 2004). In Saltasaurus, the tubera are fused (Powell, 1992, 2003).

The parasphenoid is broken in both specimens, but according to the preserved base of the cultriform process, it seems to be slender and anteriorly projected (Figs. 7C, 8).

The orbitosphenoids (Figs. 7C, 8) face anterolateraly and are pierced by several foramina for the exit of the cranial nerves (see below; Fig. 8). In anterior view, the orbitosphenoids meet each other; posteriorly they are partially fused with the laterosphenoid and dorsally they are in contact with the frontals.

Sutures of the laterosphenoids (Figs. $7 \mathrm{C}, 8$ ) with the parasphenoid, basisphenoid, and otic bones are not discernible. The laterosphenoids project laterally contacting dorsally with the frontals; contributing anterolaterally to the crista antotica. Above the crista antotica, near the frontal, there is a depression with a small foramen for the mesencephalic vein (Berman \& McIntosh, 1978).

There are no clear sutures between the exoccipital and the surrounding bones of the skull (Fig. 7). The paraoccipital processes are prominent, ventrally projected, and bear a roughly lateral surface for the articulation with the squam mosal as in Saltasaurus. These processes are situ. ated at the same level of the occipital condyles as in other titanosaurids (e.g., Antactosaurus and Rapetosaurus), with the exception of Saltasaurus where they occupy a lower position (i.e., they are longer and more ventro-anteriorly projected). The paraoccipital processes are "C »-shaped, a condition similar to that found in Saltasaurus, Antarctosaurus, and Rapetosaurus.

The prootic and opisthotic bones are strongly fused. The crista prootica is thin and dorsally delimits the middle ear cavity, which is deep and postero-ventrally faced. The fenestra oval, which accommodates the footplate of the stapes, is oval- 


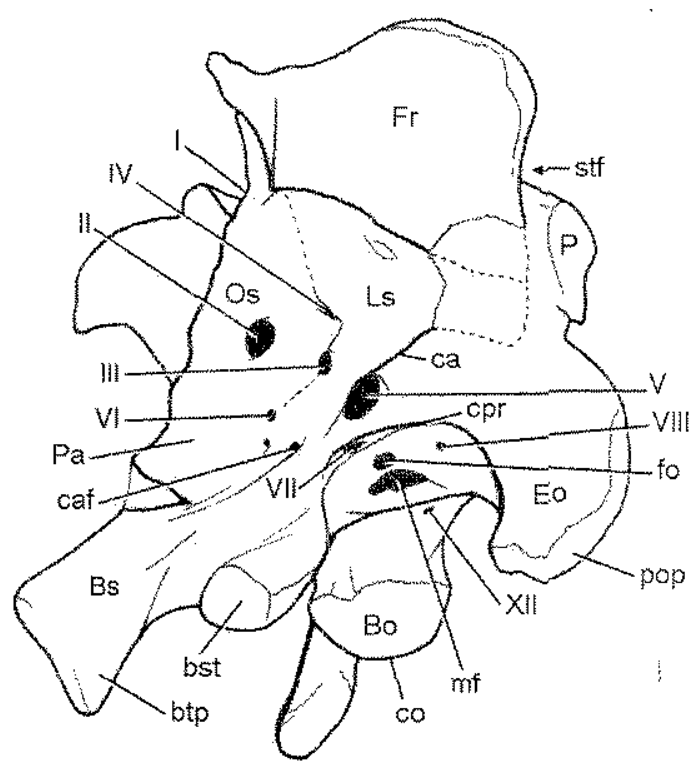

Fig. 8. Bonatitan reigi gen et sp. nou. Holotype MACN-PV RN 821, line drawing of the basicranium in ventro-lateral view with the condyle ventrally oriented. The right preserved basipterygoid process is not figured. Scale bar represents $50 \mathrm{~mm}$. Abbreviations as in Fig. 7 .

shaped and located in the center of the middle ear cavity.

Foraminae. Description of the braincase foramina (Figs $7 \mathrm{C}, 8$ ) is mainly based on the following studies: White, 1958; Berman \& Mclntosh, 1978; Salgado \& Calvo, 1992; Powell, 1992, 2003; and Galton, 1985, 1989.

The exit for cranial nerve (CN) I (olfactory tract) is relatively large and faces antero-dorsally between the orbitosphenoid and frontals as in most sauropod taxa.

The optic foramen (CN II) pierces the orbitosphenoid; it is an oval-shaped opening, facing anterolateraly, and larger than the foramen for the oculomotor nerve (CN III); this morphology is similar to Saltasaurus (Powell, 1986), Quaesitosaurus (Kurzanov \& Bannikov, 1983), and Rapetosaurus (Curry Rogers \& Forster, 2004). In Camarasaurus (White, 1958), Diplodocus (Berman \& McIntosh, 1978), Rebbachisaurus (Calvo \& Salgado, 1995), and Amargasaurus (Salgado \& Calvo, 1992) the optic and oculomotor foramina are considerably smaller and almost equal in size. In the specimen MACN-PV RN 1061 the optic foramen is relatively smaller than in MACN-PV RN 821.

The oculomotor foramen (CN III) is eyeshaped, situated on the suture between the or. bitosphenoid and laterosphenoid, and laterally faced. The anterior rim is straight with a welldefined border, while the posterior border is slightly concave. In Antarctosaurus (Huene, 1929) and Saltasaurus (Powell, 2003) this foramen is oval in shape.

The trochlear foramen (CN IV) is a very small opening, located on the suture between the orbitosphenoid and laterosphenoid, above the oculomotor foramen. The orbitosphenoid forms the anterior rim whereas the laterosphenoid forms the posterior one.

The trigeminal foramen $\left(\mathrm{CN} \mathrm{V}_{1-8}\right)$ is larger than the optic foramen, as in Saltasaurus, Antarctosaurus (Huene, 1929; Powell, 1986), and Rapetosaurus (Curry Rogers \& Forster, 2004). The trigeminal foramen is located on the suture between the laterosphenoid and the prootic, postero-ventral to the oculomotor foramen. The sharp crista antotica delimits this foramen antero-dorsally, whereas the crista prootica forms the postero-ventral rim of this foramen. The antero-ventral border of the trigeminal foramen has a groove for the maxillary branch of the trigeminal nerve $\left(\mathrm{CN} \mathrm{V}_{2}\right)$ that reaches the basipterygoid process of the basisphenoid. In Quaesitosaurus (Kurzanov \& Bannikov, 1983), Camarasaurus (White, 1958), Diplodocus (Berman \& McIntosh, 1978), Rebbachisaurus (Calvo \& Salgado, 1995), and dicraeosaurids (Janensch, 1935-36; Salgado \& Calvo, 1992) the trigeminal foramen is smaller in relation to the remaining cranial nerve foramina.

The abducens foramen (CN VI) is small and located above and anteriorly to the carotid foramen. Based on other sauropods this foramen should be located at the level of the suture between the orbitosphenoid and parasphenoid (but this suture is not clearly discernable in Bonatitan).

The facial foramen (CN VII) is small, eye shaped, and anteriorly faced. It is surrounded dorsally by the alisphenoid and ventrally by the prootic. This opening is located on the crista prootica below the foramen for the $\mathrm{CN} \mathrm{V}$.

The acoustic foramen (CN VIII) is circularshaped, smaller than the facial foramen, and placed in the middle ear cavity dorsal to the fenestra ovalis.

The glossopharyngeal (CN IX), vagus (CN X), and accessory (CN XI) nerves, and the jugular vein pass through the metotic fissure (De Beer, 1937). on the posterior wall of the middle ear cavity. This fissure is the largest opening of the lateral wall of the braincase, located postero-ventrally to the fenestra ovalis; both openings are separated by a thin bony wall. 

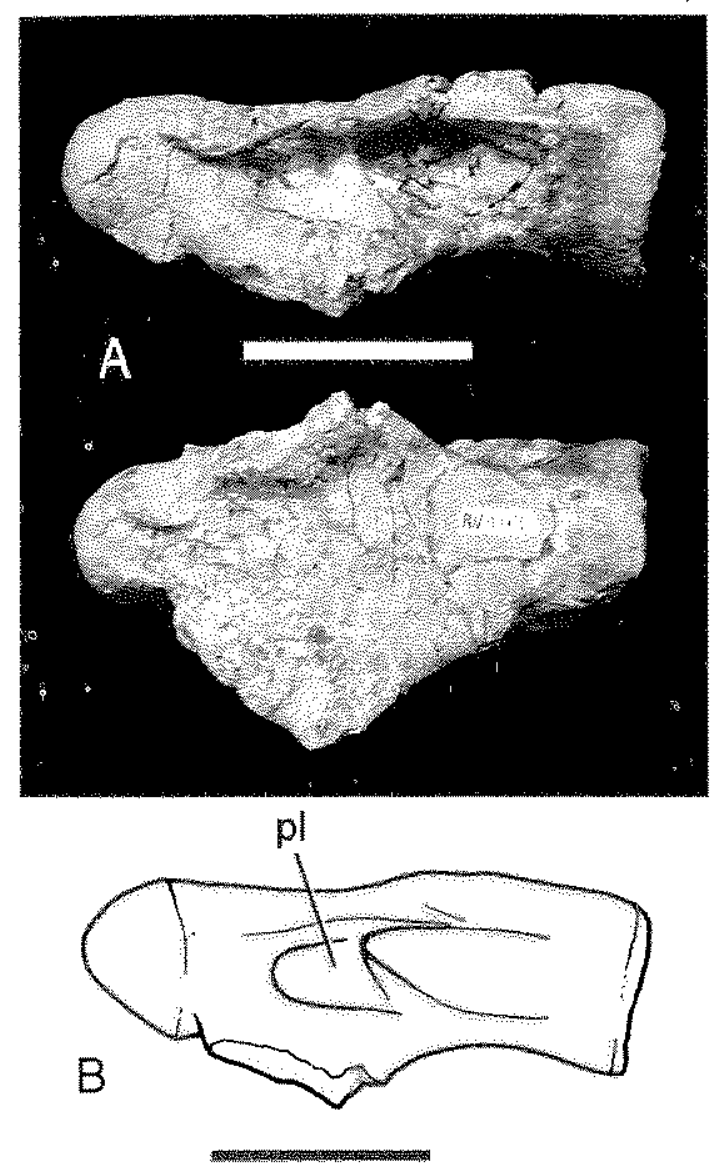

Fig. 9. Bonatitan reigi gen et $s p$. nov. MACN-PV RN 1061, photographs of the anterior cervical centrum in lateral (A) and ventral (B) views, with accompanying line drawing in lateral view (C). Scale bar represents $50 \mathrm{~mm}$. Grey pattern indicates broken areas. Abbreviations: pl, pleurocel.

The hypoglossal foramen (CN XII) opens in the exoccipital, posterior to the base of the paraoccipital process, and outside of the middle ear cavity.

The carotid foramen is fully enclosed in the basispterygid process. This opening is smaller than that of Saltasaurus and Antactosaurus. Near the carotid foramen a small indeterminated foramen is present.

\section{Postcranial skeleton}

Cervical vertebra. The cervical vertebra ( $\mathrm{Fig}$. 9) consists of an anterior centrum strongly opisthocoelous with the parapophyses located on the anterior half (the neural arch is not preserved). The centrum is almost as high as wide and very anteromposteriorly elongated, even more so than Saltasaurus (Powell, 1986, 2003; Bonaparte, 1999) and Isisaurus (Jain \& Bandyopadhyay, 1997; Wilson \& Upchurch, 2003). The pleurocoels, placed above the posterior edge of the parapophyses, are oval and deeper than in Saltasaurus. The pleurocoels are divided by an oblique septum, also present in Saltasaurus (Powell, 1986, 2003). The parapophyses are thin and latero-ventrally oriented. Due to the relative small size, this centrum is tentatively assigned to the smallest specimen (MACN-PV RN 1061).

Dorsal vertebra. An almost complete dorsal vertebra (Figs. 10,11) was recovered and based on the size it is assigned to the holotype. The left postzygapophysis and the distal portion of the neural spine are preserved and broken from the rest of the neural arch (Fig. 12). We interpret this element as a middle dorsal vertebra due to the possession of a deep postparadiapophyseal fossa (sensu Bonaparte, 1999; fossa placed posteriorly to the anterior centroparapophyseal lamina of Wilson, 1999), and because the parapophyses are high and anterior to the diapophyses. The opisthocoelous centrum is slightly deformed laterally. The centrum is as wide as high and slightly larger antero-posteriorly than wide. The pleurocoel is deep and eye-like shaped with well delimited edges as in Neuquensaurus (Powell, 2003); in Saltasaurus and Isisaurus (Jain \& Bandyopadhyay, 1997; Wilson \& Upchurch, 2003) the anterior and ventral edges of the pleurocoel slope gradually. The neural arch and the centrum are separated; both elements have cancellous osseous tissue. The posterior centrodiapophyseal lamina (pcdl) (infradiapophyseal lamina sensu Bonaparte, 1999) is thin and vertically reaches the centrum at the posterior region as in the middle dorsal vertebrae of Saltasaurus and Neuquensaurus. The thin anterior centroparapophyseal lamina (acpl) runs almost parallel to the posterior centrodiapophyseal lamina (pcdl). The articular surface of the parapophysis faces laterally and is nearer to the prezygapophysis than to the diapophysis. The prezygapophyses are located at the same level as the parapophysis, but face dorso-medially. The centroprezygapophyseal lamina is absent as in Neuquensaurus (Powell, 1986,2003 ) and Rocasaurus (Salgado \& Azpilicueta, 2000). The postparadiapophyseal fossa (pparf) is deep and constitutes the most remarkable feature in lateral view. The diapophyses are slender and are directed latero-dorsally. The postzygodiapophyseal lamina (podl) (diapopostzygapophyseal lamina sensu Bonaparte, 1999) is slender and bears on its dorsal surface some oval depressions and pits, a unique feature 

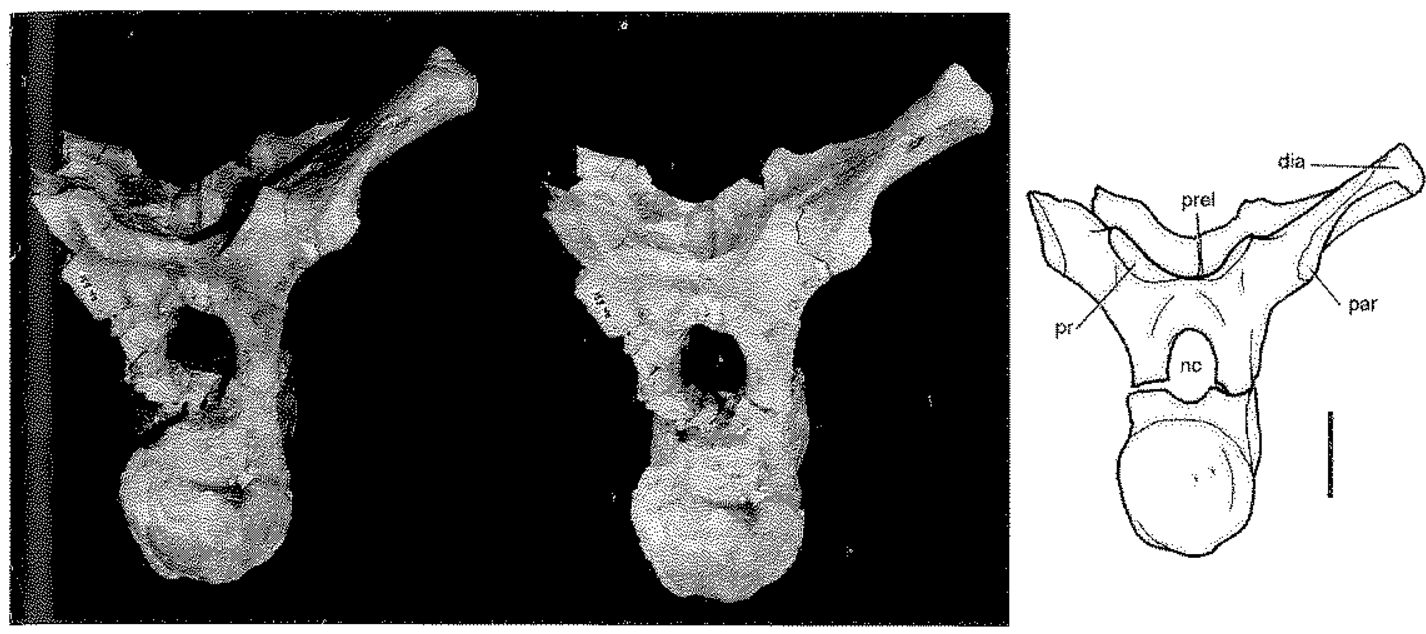

Fig. 10. Bonatitan reigi gen et sp. nov. Holotype MACN-PV RN 821, stereophotographs with accompanying line drawing of rniddle dorsal vertebra in anterior view. Scale bar represents $50 \mathrm{~mm}$. Abbreviations: dia, diapophysis; nc, neural canal; par, parapophysis; prel, prespinal lamina; pr, prezygapophysiss.
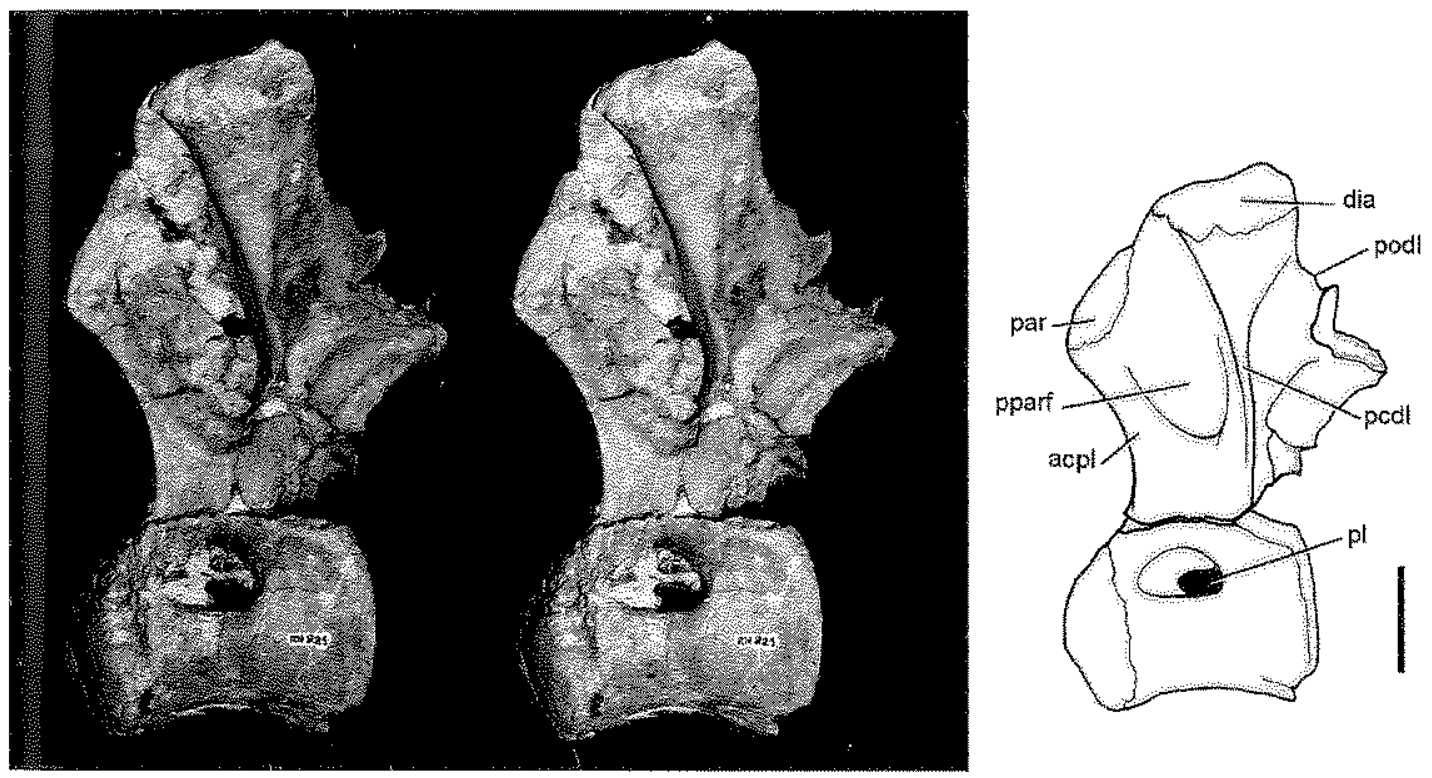

Fig. 11. Bonatitan reigi gen et sp. nov. Holotype MACN-PV RN 821, stereophotographs with accompanying line drawing of middle dorsal vertebra in lateral view. Scale bar represents $50 \mathrm{~mm}$. Grey pattern indicates broken areas. Abbreviations: acpl, anterior centroparapophysial lamina; dia, diapoplaysis; par, parapophysis; pcdl, posterior centrodiapophysial lamina; pl, pleurocel; podl, postzygodiapophysial lamina; pparf, postparapophysial fossa.

among titanosaurs. The infrapostzygapophysial lamina (tpol) is thin and incompletely preserved. The infrapostzygapophysial fossa is deep and faces posterolaterally. In the basal portion of the neural arch the prespinal lamina (prel) (spinoprezygapophyseal plus prespinal laminae, spri+prsi sensu Wilson, 1999) is thin (however it is badly preserved in the fragment of the neural spine). The undivided neural spine has its right half portion broken off (Fig. 12); it seems to be transversely wide and dorso-ventrally short. In anterior view, the prespinal lamina separates 


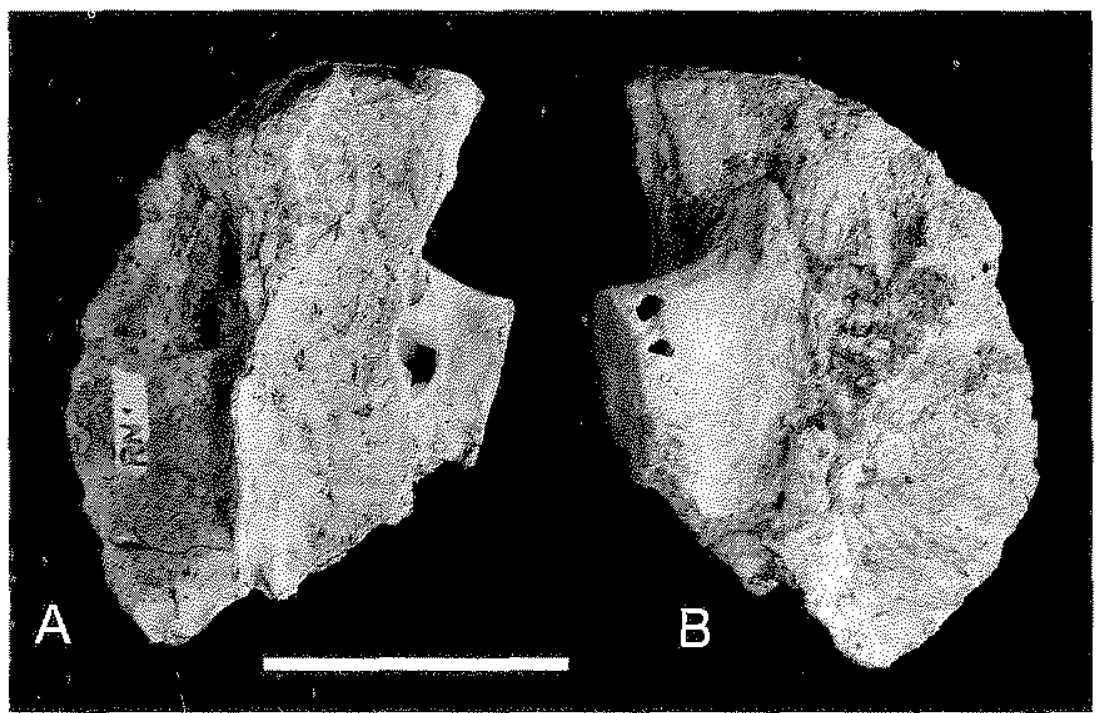

Fig. 12. Bonatitan reigi gen et sp. nov. Holotype MACN-PV RN 821, photographs of the neural spine of the middle dorsal vertebra in anterior (A) and posterior (B) views. Scale bar represents $50 \mathrm{~mm}$.

two deep lateral depressions (Fig. 12A). This por tion of the neural arch preserves the left postzygapophysis, which is extremely hollow as shown in figure 12 , and its articular surface is latero-ventrally oriented.

Caudal vertebrae. The almost complete anterior caudal vertebra (Figs. 13-15) and the neural arch of a middle caudal vertebra (Fig. 16) are preserved; they are considered to belong to the largest specimen (MACN-PV RN 821).

The anterior caudal vertebra (Figs. 13-15) is strongly procoelous, having ball and socket articular facets. The centrum is wide, short, high, and bears a prominent axial ventral crest. This feature is absent in the currently known titanosaurs and is considered an autapomorphy of Bonatitan. Saltasaurus, Neuquensaurus, and Rocasaurus have the anterior caudal vertebrae dorso-ventrally compressed (Powell, 1986, 2003; Huene, 1929; Salgado \& Azpilicueta, 2000) bearing an axial ventral depression. In Rocasaurus this depression is relatively deeper with an axial septum.

On the lateral aspect of the anterior caudal vertebra, above the axial crest, the lateral surface of the centrum is dorso-ventrally convex. Only the bases of both diapophyses are preserved. The circular shaped neural canal is longer than those preserved in the caudal vertebrae of Saltasaurus. The neural spine is low, similar to Saltasaurus. The prespinal lamina (prel) is thin, bearing well-defined oval pits on both concave lateral sides. The spinoprezygapophyseal (sprl) and the spinopostzygapophyseal (sposl) laminae are well-defined, and between each there is a deep and large interzygapophyseal fossa divided by a sub-horizontal accessory lamina (acl). The dorsal interzygapophyseal fossa extends dorsally, above the level of the postzygapophysis. The ven. tral interzygapophyseal fossa is smaller and shallower, extending ventrally to the level of the prezygapophysis. Inside both fossae there are subcircular pits similar to those present lateral to the prespinal lamina.

The prezygapophyses are anteriorly directed, and the articular surfaces face dorso-medially. The postzygapophyses are located at the level of the posterior edge of the neural spine. The postspinal lamina (postl) (medial spinopostzygapophyseal plus postspinal laminae, med. spol + posl, sensu Wilson, 1999) is wider than the prespinal one.

The middle caudal neural arch (Fig. 16) is not completely fused to the vertebral centrum. The neural spine is short, robust but extremely hollow, and steeply inclined backwards. The anterodorsal corner of the spine is at the same level of the poste rior edge of the postzygaphophysis as in Saltasaurus, Neuquensaurus, and Rocasaurus (Fig. 17). This feature was considered a synapomorphy of the Saltasaurinae (Salgado et al, 1997a). The prespinal lamina divides two deep depressions, as occurs in the neural arch described above. Inside these depressions there are deep pits decreasing posteriorly in size. A similar feature, but not as de- 

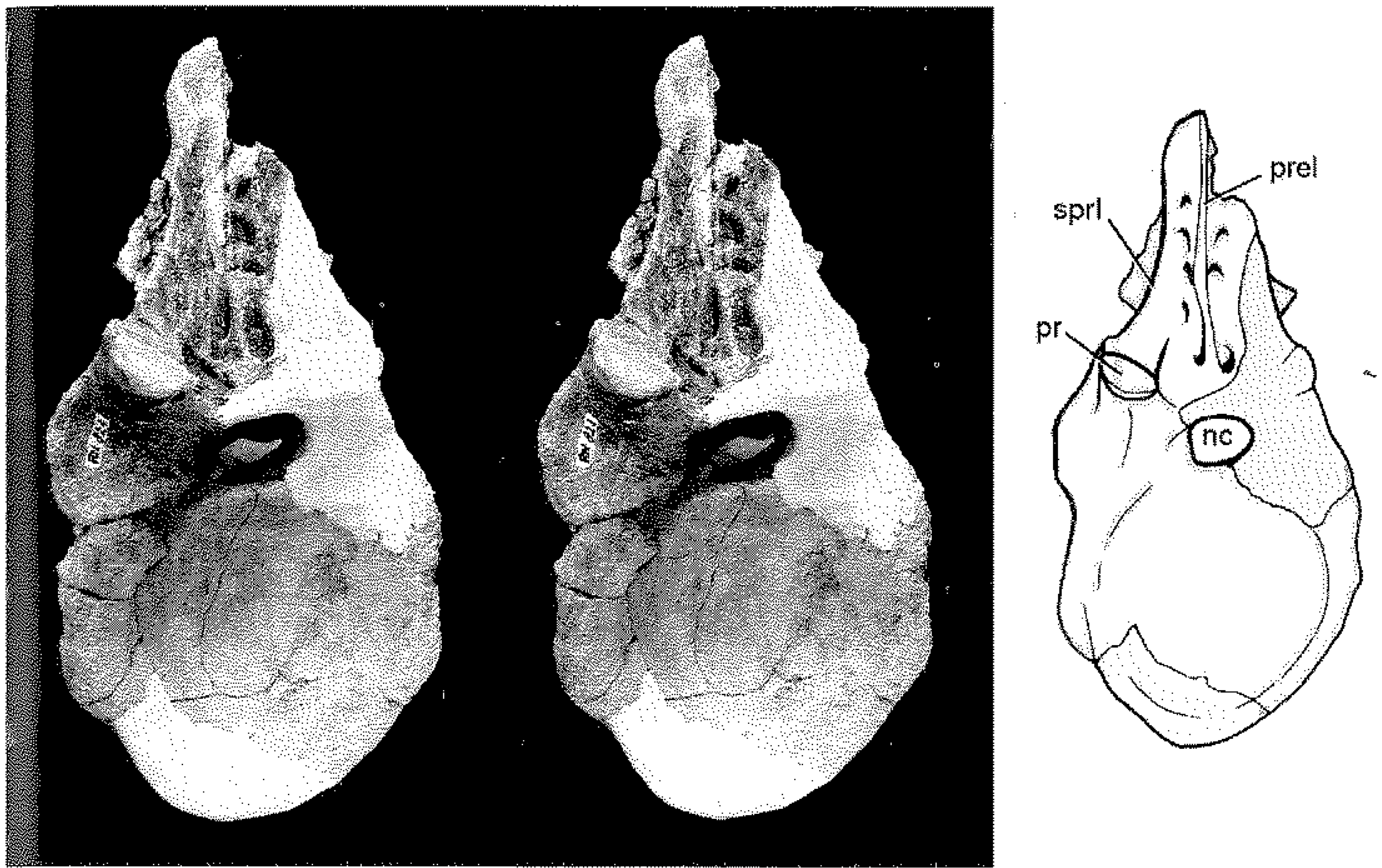

Fig. 13. Bonatitan reigi gen et sp. nou. Holotype MACN-PV RN 821, stereophotographs with accompanying line drawing of the anterior caudal vertebra in anterior view. Scale bar represents 50 mm. Grey pattern indicates broken areas. Abbreviations: nc, neural canal; prel, prespinal lamina; pr, prezygapophysis; sprl, spinoprezygapophysial lamina.
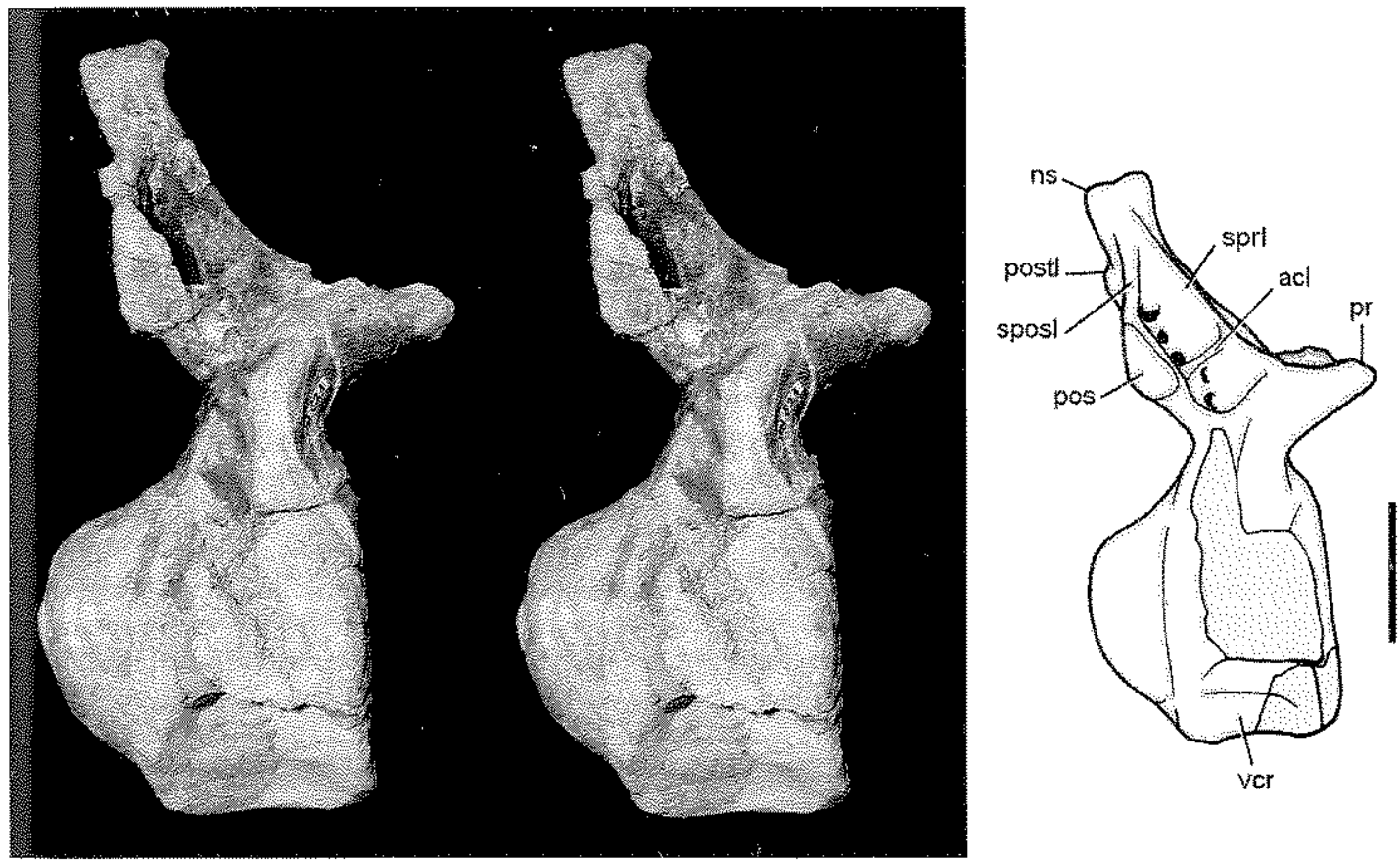

Fig. 14. Bonatitan reigi gen et sp. nov. Holotype MACN-PV RN 821, stereophotographs with accompanying line drawing of the anterior caudal vertebra in lateral view. Scale bar represents 50 $\mathrm{mm}$. Grey pattern indicates broken areas. Abbreviations: acl, accessory lamina; ns, neural spine; pos, postzygapophysis; postl, postspinal lamina; pr, prezygapophysis; sposl, spinopostzygapophysial lamina; sprl, spinoprezygapophysial lamina; ver, ventral crest. 


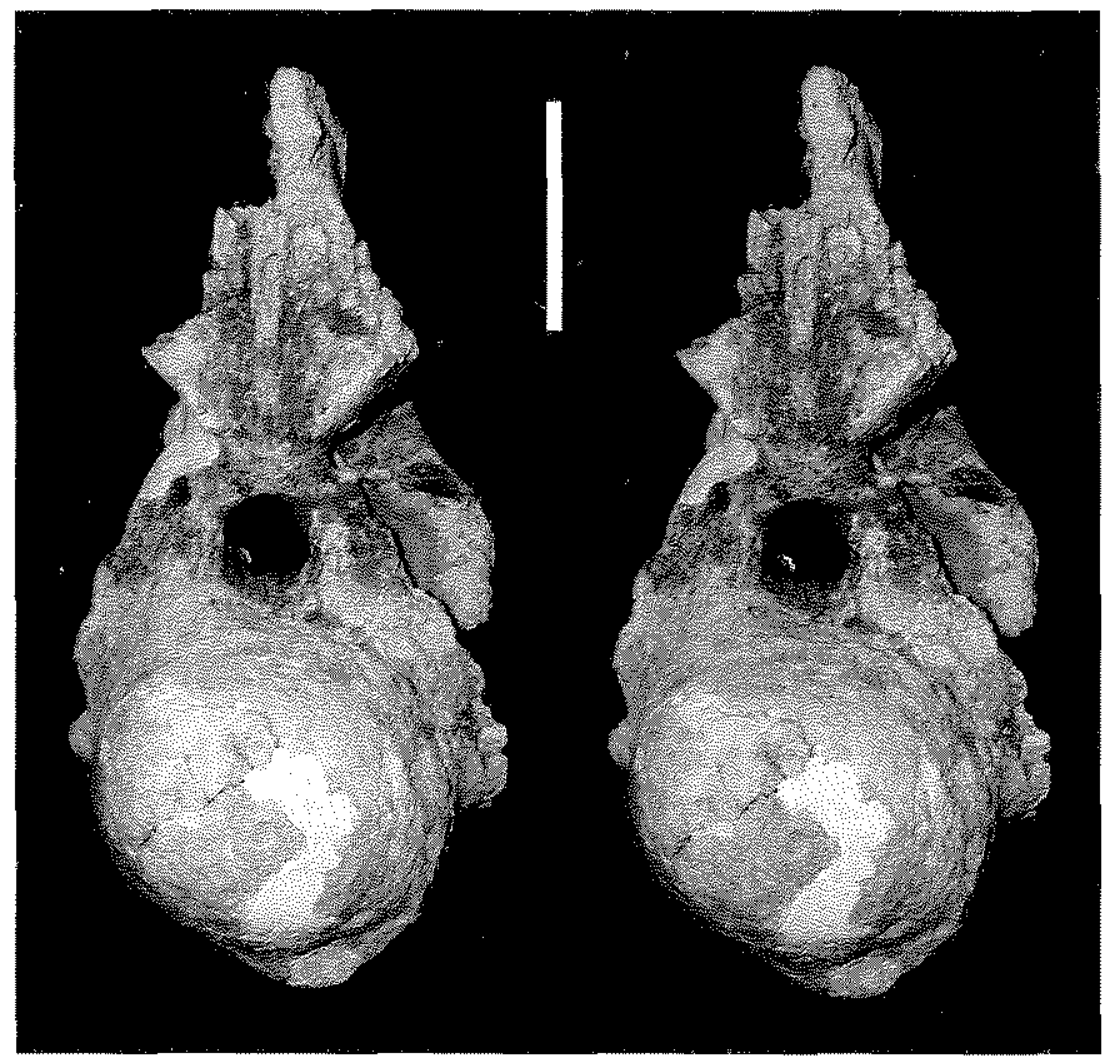

Fig. 15. Bonatitan reigi gen et sp. nov. Holotype MACN-PV RN 821, stereophotographs of the anterior caudal vertebra ir posterior view. Scale bar represents $50 \mathrm{~mm}$.

veloped as in this new species, is observed in the middle caudal vertebrae of Neuquensaurus (Powell, 2003: Plate 58). The prezygapophyses are prominent, antero dorsally directed with the articular surfaces dorso-medially exposed. The postspinal lamina is more prominent and robust than the prespinal one. Between both postzygapophyses, at the base of the postspinal lamina, there is a deep fossa similar to Neuquensaurus (Powell, 2003).

Humerus. A complete left humerus (Fig. 18A) was recovered and assigned to the holotype. The humerus is more slender than in Neuquensaurus and Saltasaurus (Huene, 1929; Powell, 1986, 1992, 2003). The humeral head and deltopectoral crest are poorly developed similar to Laplatasaurus (Huene, 1929), Lirainosaurus (Sanz et al., 1999), and Rapetosaurus (Curry Rogers \& Forster, 2001); instead, Neuquensaurus and Saltasaurus have a more prominent head and robust deltopectoral crest. The shaft is narrow and the proximal end is wider than the distal one. The proximal end is slightly rotated in relation to the distal one. Both distal epicondyles are not well developed. The humerus length relation with the femur is approximately 0.8 .

Ulna. The left ulna (Fig. 18B) is completely preserved and belongs to the smaller specimen (MACN-PV RN 1061). This element is more slender than in Neuquensaurus and Saltasaurus (Huene, 1929; Powell, 1986, 1992, 2003). The proximal end is rugose, slightly convex and subtriangular, with a concave proximal border of the radial fossa (Fig. 18B). The olecranon process is absent. Proximally, the antero-lateral surface of the ulna is concave for the articulation with the radius. The posterior surface of the shaft is almost plane and bears a ridge on its distal half that ends near the distal end. The distal surface is also rugose, rectangular in cross section, and transversely narrower than the proximal end of the bone.

Radius. A left radius is incompletely preserved and also belongs to the smaller specimen. The proximal end is broken on the antero-medial edge. The shaft is oval in cross section, and 

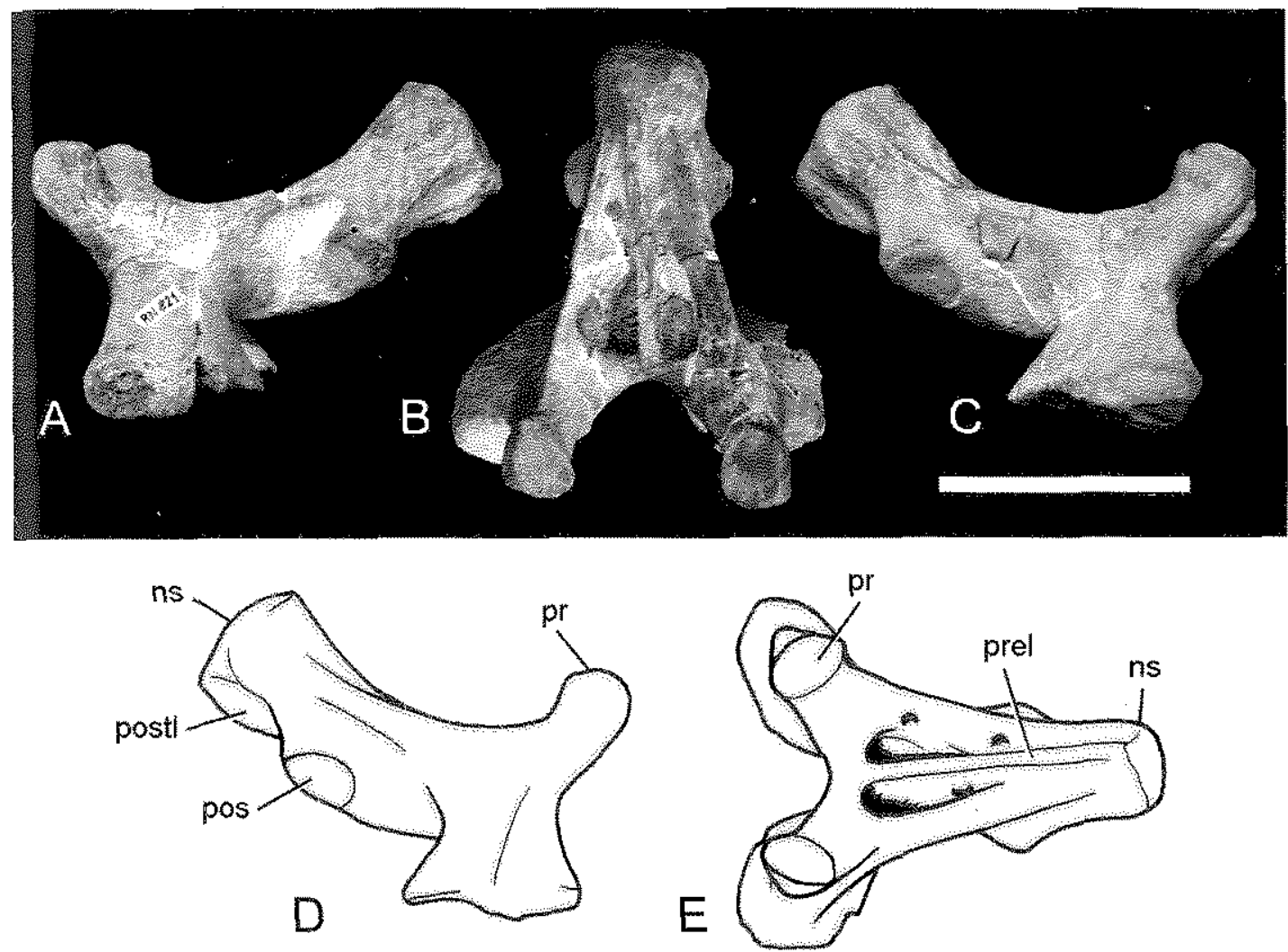

Fig. 16. Bonatitan reigi gen et $s p$. nov. Holotype MACN-PV RN 821 , photographs of the middle caudal neural arch in left lateral (A), dorsal (B), and right lateral (C) views, and accompanying line drawing in lateral (D) and dorsal (E) views. Scale bar represents $50 \mathrm{~mm}$. Abbreviations: ns, neural spine; pos, postzygapophysis; postl, postspinal lamina; prel, prespinal lamina; pr, prezygapophysis.

the surface for una articulation is concave. Most of the distal end is missing.

Femur. The holotype has preserved both femora (Fig. 18C), and MACN-PV RN 1061 only the left element. The femur is antero-posterioly flat, bearing on the latero-proximal edge a slightly marked bulge, as in other Titanosauriformes (Salgado et al., 1997a; Wilson \& Sereno, 1998). The femoral head is rather medial than dorso-medially projected. The medial border of the femoral head is more curved in MACN-PV RN 1061 (as in Saltasaurus and Neuquensaurus; Powell, 1986, 2003) than in the holotype. The greater trochanter is located at the level of the head, and the fourth trochanter is not evident. The tibial condyle is more prominent and more distally developed than the fibular one as it is observed in Neuquensaurus and Saltasaurus, but different from Rocasaurus that has similar sized condyles (Salgado \& Aspilicueta, 2000). Both condyles are expanded onto the anterior surface of the femo- ral shaft; there is an intercondylar notch between them.

Tibia. Both tibiae (Fig. 18D) were recovered for the holotype, while only the left one for the referred material (Fig. 18E). The tibia is nearly $12 \%$ smaller than the femur. The proximal end is antero-posteriorly narrower than in Neuquensausus and Saltasaurus (Huene, 1929; Powell, 1992, 2003), and quite similar to Laplatasaurus (Huene, 1929). The cnemial crest is thin and poorly developed, differing from Neuquensaurus and Saltasaurus in which it is robust and prominent. The distal end is transversely broad as in other titanosaurs (Salgado et $a l ., 1997 a)$. The main axis of the proximal surface has a relation of aproximately $90^{\circ}$ with the main axis of the distal surface, similar to Saltasaurus and Neuquensaurus (Powell, 1992; Sanz et al., 1999).

Fibula. Only the complete left fibula (Fig. $18 \mathrm{~F}$ ) assigned to the holotype is preserved. This is a relatively straight and slender bone with a 


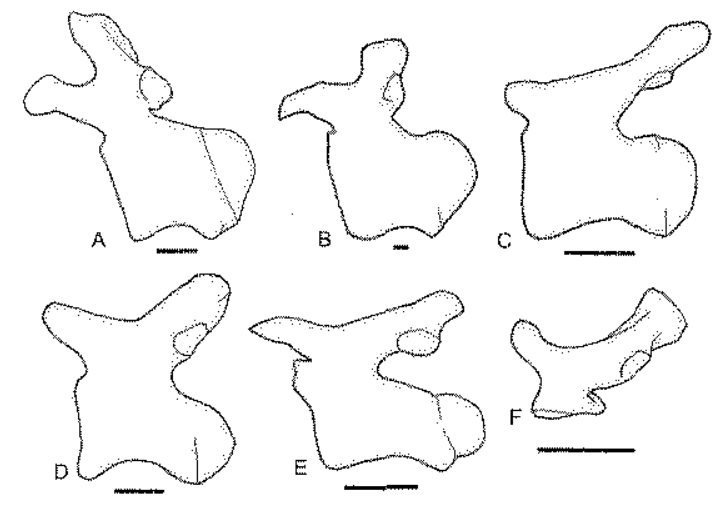

Fig. 17. Comparison of middle caudal vertebra among Titanosauridae in lateral view. A. Aeolosaurus sp. (modified from Salgado \& Coria, 1993); B. Alamosaurus sanjuanensis (modified from Gilmore, 1946); C. Neuquensaurus australis (modified from Salgado \& Coria, 1993); D. Saltasaurus loricatus (modified from Powell, 1992); E. Rocasaurus muniozi (modified from Salgado \& Azpilicueta, 2000); F. Bonatitan reigi gen et sp. nov. Scale bar represents $50 \mathrm{~mm}$.

weak antero-lateral tuberosity located above the middle of the shaft. The proximal articular surface is triangular; in contrast, the distal one is oval. This bone is slightly shorter than the tibia.

Metatarsal $I$. The left metatarpal $I$ is assigned to the holotype specimen. This bone is short and robust (Fig. 18G). The proximal surface is slightly convex and subrectangular with the posteromedial corner posteriorly projected. The posterior surface of the shaft is concave and the anterior one is almost straight. The shaft is transversely narrow. The distal surface is also rectangular with the lateral area distally projected. This metatar. sal closely resembles that of Neuquensaurus (Huene, 1929) and Aeolosaurus sp. (Salgado et al., 1997b), with the shaft more slender than in Antarctosaurus (Huene, 1929).

Metatarsal III. This metatarsal is smaller in comparison to metatarsal $I$ and it is assigned to the smallest specimen (MACN-PV RN 1061). The proximal surface is triangular, antero-posteriorly elongated, and slightly convex. The distal surface is rectangular and transversely wide. The narrower section of the shaft is located in the lower half of the bone. The anterior surface is flat while the posterior one is strongly concave.

\section{Comments of Bonatitan reigi}

The subfamily Saltasaurinae, proposed by Powell (1986), was phylogenetically defined as the clade that includes the more recent common ancestor of Neuquensaurus australis and Saltasaurus loricatus, and all its descendants (Salgado et al., 1997a). This group was originally diagnosed by Salgado et al. (1997a) based on the following derived features: a) short cervical prezygapophyses near the level of the diapophyses; b) depressed anterior caudal centra, with dorsoventrally convex lateral faces; and c) anterodorsal edge of the neural spine located posteriorly with respect to the anterior root of the middle-caudal postzygapophyses. In addition, the presence of cancellous osseous tissue in presacral and anterior caudal vertebrae was considered another synapomorphy of Saltasaurinae (Powell, 1986).

Curry Roger \& Forster (2001) interpreted Saltasaurinae as a more inclusive taxon, which includes Alamosaurus, Titanosaurus, Opisthocoelicaudia, Neuquensaurus, and Saltasaurus. These taxa were nested together due to the presence of four unambiguous traits: biconvex first caudal centrum, deltopectoral crest reduced to a low rounded crest, manual digits II and MI without phalanges, and proximal breadth of the tibia more than twice its midshaft breadth (Curry Roger \& Forster, 2001). Wilson (2002: 269) interpreted Saltasaurinae as composed by Neuquensaurus plus Saltasaurus, sharing four unequivocals features: cervical neural arch lamination well developed; spongy caudal bone texture; posterior caudal centra dorso-ventrally flattened; and femoral distal condyles exposed on the anterior portion of the femoral shaft. This subfamily, together with Opisthocoelicaudinae, comprise the family Saltasauridae proposed by Sereno (1998) in replacement of Titanosauridae.

Later, in order to clarify the term Titanosauridae, Salgado (2003) reviewed and established a new taxonomic proposal for the highertaxa of Titanosauria. In his work, the family Titanosauridae was justificated as a valid name, instead of Saltasauridae (see Salgado, 2003). Also, Salgado (2003) redefined Saltasaurinae as all the eutitanosaurs closer to Saltasaurus than to Opisthocoelicaudia (following the interpretation of Sereno, 1998; Wilson, 2002; Wilson \& Upchurch, 2003). In addition, Saltasaurinae and Opisthocoelicaudiinae (Sereno, 1998) are nested within the stem-based taxon Eutitanosauria (proposed by Sanz et al., 1999).

Hitherto known, following the latter phylogenetic definitions of Saltasaurinae (sensu Sereno, 1998; Wilson, 2002; Salgado, 2003; Wilson \& Upchurch, 2003), the members are Saltasaurus loricatus from the CampanianMaastrichtian of the El Brete Formation (Salta 


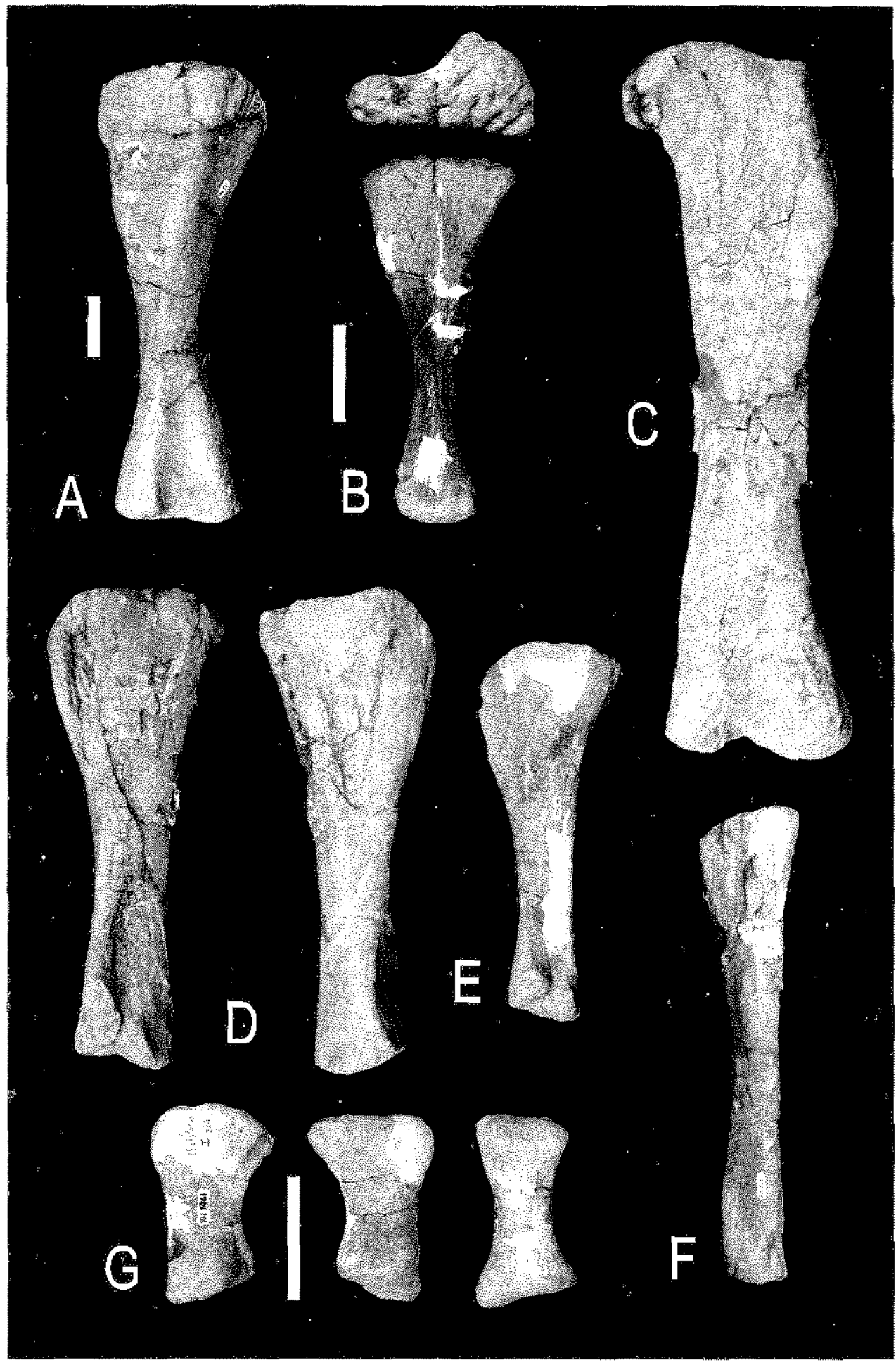

Fig. 18. Bonatitan reigi gen et sp. nov. Holotype MACN-PV RN 821, photographs of A. left humerus in posterior view; B. left ulna in posterior and proximal views; C. left femur in anterior view; D. left tibia in lateral and medial views; $E$. left tibia in lateral view (juvenile specimen MACN-PV RN 1061); F. left fibula in lateral view; G. left metatarsal I in lateral, medial and posterior views. Scale bar represents $50 \mathrm{~mm}$. Figs. A, C-F are at the same scale. 
Province, Argentina; Bonaparte \& Powell, 1980; Powell, 1986, 1992), Neuquensaurus australis from the Coniacian-Santonian of the Bajo de la Carpa Formation (Neuquén Province, Argentina; Lyddeker, 1893; Huene, 1929; Powell, 1992), and Rocasaurus muniozi from the CampanianMaastrichtian of the Allen Formation (Río Negro Province, Argentina; Salgado \& Azpilicueta, 2000).

Bonatitan reigi shares the typical titanosauriform feature of a lateral bulge in the femur (McIntosh, 1990; Salgado et al., 1997a); and titanosaur features, including eye-shaped pleurocoels in dorsal vertebrae, posterior dorsal vertebra with ventrally wide centrodiapophyseal and centroparapophyseal laminae and procoelous anterior caudal centra (Calvo \& Bonaparte, 1991; Bonaparte \& Coria, 1993; Salgado et al., 1997a; Wilson, 2002).

Bonatitan reigi is here considered as a new Saltasaurinae because it exhibits the following diagnostic features of the subfamily: 1) Anterodorsal edge of the neural spine at the posterior level of the postzygapophyses in the middle caudal neural arch (Fig. 16). Contrary, other nonsaltasaurine titanosaurids such as Aeolosaurus (Powell, 1987a; Salgado \& Coria, 1993; Salgado et al., 1997b) and Alamosaurus (Gilmore, 1946) have the neural spine dorsally or anteriorly projected (Fig. 17). 2) Distal femoral condyles anteriorly exposed. This feature was also recognized in Rapetosaurus (Curry Rogers \& Forster, 2001). 3) Cancellous osseous tissue in the presacral and caudal vertebrae, mainly observed in the neural arches. Other synapomorphies of Saltasaurinae such as the presence of short cervical prezyga. pophyses and depressed proximal and middle cau" dal centra is unknown in the two available specimens of Bonatitan. The only caudal centrum preserved in Bonatitan is not dorso-ventrally depressed, instead it bears a prominent axial crest on the ventral surface that is interpreted to be an autapomorphy of this new species.

Among saltasaurines, the appendicular bones of Bonatitan reigi are more slender than those of Saltasaurus and Neuquensaurus, taxa in which these elements have a more robust aspect with well developed processes (e.g, cnemial crest in the tibia). The femur is the only appendicular bone that can be compared with Rocasaurus; it is quite similar in both species, only differing in the relative size of the distal condyles (in Rocasaurus are almost equal, whereas in Bonatitan the medial condyle is larger than the lateral one). Thus, the appendicular bones of Bonatitan (and also of Rocasaurus) show a more basic plan, common with other titanosaurids such as Laplatasaurus and Rapetosaurus.

The presence of spinoprezygapophyseal and spinopostzygapophyseal laminae in the anterior caudal vertebra of Bonatitan is a feature also reported in Mendozasaurus neguyelap (González Riga, 2003), Lirainosaurus astibiae (Sanz et al,, 1999), and Rapetosaurus krausei (Curry Rogers \& Forster, 2001). Furthermore, the presence of an interzygapophysial fossa in the anterior caudal vertebrae was recognized in Lirainosaurus (Sanz et al., 1999), Mendozasaurus (González Riga, 2003), and less developed in Malawisaurus (Gomani et al., 1999). These characters that show a significant variation among species need to be re-analized in order to understand their evolutionary transformation among titanosaurs.

Despite the large number of titanosaur species discovered around the world, only few specimens have preserved cranial elements. Skull bones are known in Antarctosaurus wichmannianus (Huene, 1929), Saltasaurus loricatus (Powell, 1986, 1992), Malawisaurus dixeyii (Jacobs et al., 1993), Nemegtosaurus mongolienisis (Nowinski, 1971), Quaesitosaurus orientalis (Kurzanov \& Bannikov, 1983), Rapetosaurus krausei (Curry Rogers \& Forster, 2001, 2004), Lirainosaurus astibiae (Sanz et al., 1999), and unnamed taxa from India (Berman \& Jain, 1982), Europa (Le Loeuff et al., 1989; Weishampel et al., 1991), and Argentina (Calvo et al., 1997a; Martinez, 1998; Coria \& Salgado, 1999). Controversial hypotheses concerning the skull morphology (a diplodocid or camarasaurid aspect), orientation and relation. ship of the skull bones (McIntosh, 1990; Calvo, 1994; Jacobs et al., 1993; Salgado \& Calvo, 1997; Upchurch, 1995, 1999) were partially clarified after the discovery of Rapetosaurus krausei (Curry Rogers \& Forster, 2001, 2004; Wilson, 2002), which has the best preserved and fairly complete skull among titanosaurs.

The skull of Bonatitan shows some differences with regards to Saltasaurus, including unfused basipterygoid tubera of the basisphenoid (in Saltasaurus these are thick and fused; Powell, 1992, 2003); paraoccipital process located at the same level of the occipital condyle (in Saltasaurus they are below that level); and reduced and pos" teriorly placed carotid foramen. In Bonatitan, the basipterygoid tubera are twice dorso-ventrally longer than transversely; in contrast, Antarctosaurus and Rapetosaurus have robust and short tubera almost as long as wide (Huene, 1929; Curry Rogers \& Forster, 2004). The basipterygoid processes of the basisphenoid are divergent in Bonatitan, while in Antarctosaurus they almost 
form a straight angle and in Rapetosaurus they are almost parallel. In consequence, the main axis of the basipterygoid tubera coincides with the main axis of the basipterygoid processes in Antarctosaurus, while in Bonatitan and Rapetosaurus the basipterygoid tubera are more divergent than the basipterygoid processes.

Among titanosaurids only Bonatitan, Saltasaurus, Antarctosaurus, and Rapetosaurus have a large trigeminal foramen (CN V). This foramen is very reduced in Quaesitosaurus (Kurzanov \& Bannikov, 1983) and the other nontitanosaurid neosauropod (e.g., Madsen et al., 1995; Berman \& McIntosh, 1978). The optic foramen is relatively large in Bonatitan, Saltasaurus, Quaesitosaurus, and Rapetosaurus while it is reduced in other neosauropods such as brachiosaurids or dicraeosaurids. The overall comparison with others titanosaurids suggest that the cranial morphology of Bonatitan represents a generalized titanosaurid morphology.

\section{SAUROPOD EGGS}

The knowledge about sauropod eggs and nesting behavior increased distinctively over the last few years in South America (e.g., Powell, 1987a; Chiappe et al., 1998; Casadio et al., 2002). One of the most important locality from South America is Auca Mahuevo (northern of Neuquén Province; Anacleto Formation) in which abundant sauropod eggs and embryos in situ has been discovered (Chiappe et al. , 1998). Additional Cretaceous eggshell remains have been found in the Río Colorado (Calvo et al., 1997b), Los Alamitos (Powell, 1987a), Allen (Powell, 1987c, 1991), Colorado (Casadio et al., 2002), and Los Blanquitos (Powell, 1994) formations of Argentina; the Mercedes Formation of Uruguay (Mones, 1980); the Bauru Group of Brazil (Price, 1951); and the Vilquechico and Bagua (e.g., Sigé, 1968) formations of Perú. Both the Megaloolithidae and Faveollolithidae oofamilies were recognized in these beds (e.g., Mones, 1980; Powell, 1987a \& c, 2003; Chiappe et al., 1998; Casadío et al., 2002). The eggshells preliminary reported from the Allen Formation were assigned to Sphaerovum erbeni (Faveollolithidae) (Casadío et al., 2002). In 1990 a great abundance of eggshells and nests in the area of the Bajo de Santa Rosa in the upper mem. ber of the Allen Formation were discovered indicating an important sauropod nesting ground. Posteriorly to the discovery, this region was looted and the fossiliferous richness of eggs and eggshells decreased drastically.
Faveoloolithidae Zhao \& Ding, 1976

Sphaerovum erbeni Mones, 1980

(Fig. 19)

Referred Material. MACN-PV RN 1088: thousands of isolated eggshell fragments and seven eggs almost complete.

Description. The eggs are spherical and the diameter varies from 180 to $210 \mathrm{~mm}$. The eggshells are thick and vary from 5 to $6 \mathrm{~mm}$. The morphotype is filispherulithic (small narrow spherulites that converge one with another leaving surrounding pores; Mikhailov, 1991); the eggshells have a multicanaliculate pore system (Mikhailov, 1991).

Comments. The eggshells here described have a filispherulithic morphotype, a multicanaliculate pore system, and compactituberculate external ornamentation, a set of features diagnostic of the species Sphaerovum erbeni Mones (Casadío et al., 2002). The filispherulithic morphotype characterizes the Faveoloolithidae oofamily (Mikhailov, 1991).

\section{Megaloolithidae Zhao, 1976 Gen. et sp. indet.}

Referred Material. MACN-PV RN 1096: fragments of eggshells and eight partial eggs.

Description. These eggshells are thin (about 2 $\mathrm{mm}$ trick) and scarcer than the Faveoloolothidae. The more complete egg is subspherical, approximately $120 \mathrm{~mm}$ in diameter. The external surface is covered with spherical, dome-shaped tubercles that are tightly in contact each other. This type of compactituberculate ornamentation is common in Megaloolithidae taxa (Mikhailov, 1991), as well as in Sphaerovum erbeni (Faveoloolithidae; Casadio et al., 2002). The morphology of the shell in these remains is tubospherulithic (shell units sharply separated defining tuberculous elevations on the external surface; Mikhailov, 1991), and has a tubucanaliculate pore system.

Comments. The tubospherulitic morphology of these remains suggests megaloolithid affinities and clearly indicates the presence of another taxon different to Sphaerovum erbeni.

\section{THEROPODS}

The record of theropod dinosaurs in the Allen Formation is scarce in comparison with other Cretaceous formations of Patagonia. The theropods described from the Allen Formation are the abelisaurid Quilmesaurus curriei (Coria, 2001; Kellner \& Campos, 2002), and a yet 
undescribed deinonychosaurian (Novas et al., 2003b) from Bajo de Santa Rosa. Abelisaurus comahuensis was originally considered as coming from the Allen Formation (Bonaparte \& Novas, 1985), but according to recent geological studies this taxon belongs to the older Río Colorado Subgroup (Heredia \& Salgado, 1999).

Saurischia Seeley, 1888

Theropoda Marsh, 1881

cf. Carcharodontosauridae Stromer, 1931

Gen. et sp. indet.

(Fig. 20A)

Referred Material. MACN-PV RN 1086: an isolated tooth.

Description. The only non-avian theropod remains reported in this present study consists of a small serrated tooth represented by a fragmen. tary crown (Fig. 20A). For descriptive purposes the most convex serrated edge is interpreted as mesial and the most flat surface of the tooth as lingual (i.e., the tip of the tooth is inclined distally and lingually).

The preserved crown height is $19 \mathrm{~mm}$, with a maximum mesio-distal width of $11 \mathrm{~mm}$ at the base. The mesial carina is slightly more curved than the distal one. The carina bears about 9 denticles in $5 \mathrm{~mm}$. Well developed blood grooves are present between succesive denticles as occurs in Carcharodontosauridae, Tyrannosauridae, Dromaeosauridae, and Allosaurus (e.g., Currie et $a l ., 1990)$. The crown is transversely narrow at the top, but wide at the botton. The labial surface is dorso-ventrally and mesio-distally convex. The tip of the crown is slightly inclined lingually. On both surfaces, close to the mesial and distal edges the enamel is wrinkled, forming obliquely oriented bands that extend from the carina to the midline of the crown. These bands are more evident on the lingual side (Fig. 20A).

Comments. The wrinkled condition of the enamel leads us to consider this specimen as cf. Carcharodontosauridae, a feature that was interpreted as diagnostic for the family (e.g., Sereno et al., 1996; Larsson, 1996; Candeiro, 2002). Nevertheless, it is worth mentioning that carcharodontosaurid teeth has a height of approximately $100 \mathrm{~mm}$, differing considerably with regards to the very small taxon described here.

The most complete record of Carcharodontosauridae in Patagonia is Giganotosaurus carolinii (Coria \& Salgado, 1995) represented by an almost complete skeleton from the AlbianCenomanian Candeleros Formation of Neuquén. In addition, isolated teeth and skeletal remains

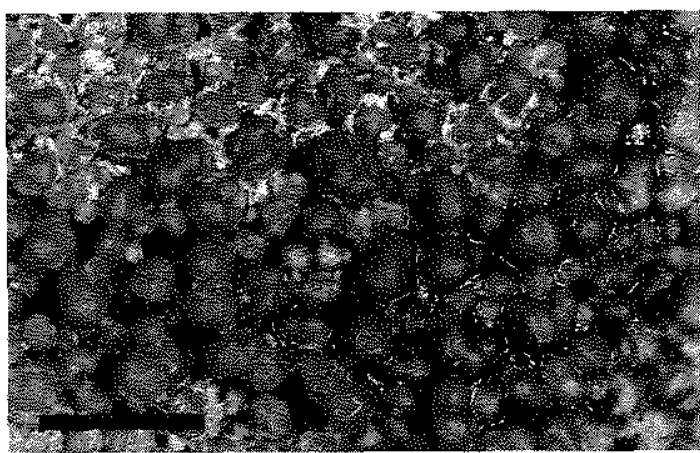

Fig. 19. Sauropod eggshell. MACN-PV RN 1088, detail of the external surface of the eggshell of Sphaerovum erbeni Mones. Scale bar represents $2 \mathrm{~mm}$.

assigned to this family were reported from the Cerro Barcino (Aptian; Chubut Province; Novas \& de Valais, 2001; Vickers-Rich et al., 1999), Candeleros (Albian-Cenomanian; Río Negro) (de Valais \& Apesteguía, 2001), Mata Amarilla (Turonian; Chubut Province; Novas et al., 1999), and Anacleto (Santonian; Neuquén Province; Alcober et al., 1998) formations. Furthermore, teeth referred as Carcharodontosauridae were collected from the Sáo Luis Basin (Cenomanian; Norther Brazil; Vilas-Boas et al., 1999), and Adamantina (Turonian-Santonian) and Marília (Maastrichtian) formations from São Paulo and Minas Gerais (Brazil; Candeiro, 2002; Candeiro et al., 2002).

The Abelisauridae is another well known family of basal neotheropods widely documented in the Late Cretaceous of Patagonia (Bonaparte, 1991; Bonaparte \& Novas, 1985; Bonaparte et al., 1990; Coria et al., 2002). Abelisaurid teeth lack wrinkled enamel near the carina and lack blood grooves between denticles (Bertini, 1996; Bittencourt \& Kellner, 2002).

The record of a tentatively Carcharodontosauridae in the Allen Formation at the Bajo de Santa Rosa locality is a significant find because the large sized members of this family (e.g., Giganotosaurus carolinii, Carcharodontosaurus saharicus; Coria \& Salgado, 1995; Sereno et al., 1996), which proliferated during the AptianTuronian times in South America and Africa, are poorly represented in the fossil record during the Coniacian to Maastrichtian times.

If the wrinkled enamel of carcharadontosaurids is a diagnostic trait not recordered in others neotheropod taxa, this tooth could represent the first record of the family in the CampanianMaastrichtian of Patagonia, and together with 
those specimens from the Maastrichtian Marília Formation (Brazil; Candeiro et al., 2002) may suggest the persistence of this family throughout the uppermost Cretaceous in South America.

\section{ORNITHISCHIANS}

The occurrence of ornithischian dinosaurs in the Allen Formation is based on vertebral and sacral remains of a Lambeosaurinae (Powell, $1987 \mathrm{~b})$ and a few isolated bones and dermal plates of a probable Nodosauridae (Ankylosauria) from Salitral Moreno, Río Negro Province (Salgado \& Coria, 1996; Coria \& Salgado, 2001), and fragmentary postcranial elements of a Hadrosauridae (closely related to Kritosaurus australis) from the west of La Pampa Province (González Riga \& Casadío, 2000).

In the Los Alamitos Formation several skeletons of Kritosaurus australis (Bonaparte et al., 1984; Bonaparte \& Rougier, 1987) have been discovered, representing the best-known record of this group for the Late Cretaceous of South America. Fragmentary remains of indeterminated Hadrosauridae were also reported from the Paso del Sapo (Chubut Province; Apesteguía \& Cambiaso, 1999), Coli Toro (Río Negro Province; Coira, 1979), and La Colonia (Hill et al., 2002) formations.

Ornithischia Seeley, 1888

Ornithopoda Marsh, 1871

Hadrosauridae Cope, 1869

Gen. et sp. indet.

(Figs. 20B-C)

Referred Material. MACN-PV RN 1085: five maxillary fragments and several tooth fragments.

Description. The best preserved fragment of a maxilla (Fig. 20B) recovered at Bajo de Santa Rosa shows same-sized alveolii located close to each other and separated by alveolar septa. De. spite the lack of synapomorphies, the morphology and size of the maxilla resembles that observed in some ornithopod hadrosaurs, such as Kritosaurus australis (Bonaparte et al., 1984; Bonaparte \& Rougier, 1987) from the Los Alamitos Formation. The teeth are poorly preserved; in the enameled labial surface they have a strong median carina (Fig. 20C) that is only present in Hadrosauridae (Weishampel \& Horner, 1990).

\section{DISCUSION}

\section{Paleoenvironmental aspects}

The Allen Formation is exposed in La Pampa and Río Negro Provinces (Argentina). This unit has previously provided Elasmosauridae plesiosaurs (near Lago Pellegrini; Gasparini \& Salgado, 2000); Lambeosaurinae (Salitral Moreno; Powell, 1987b), Hadrosauridae (Puelén; González Riga \& Casadio, 2000), and Nodosauridae (Salitral Moreno; Salgado \& Coria, 1996; Coria \& Salgado, 2001) ornithischians; the abelisaurid Quilmesaurus curriei (Salitral Ojo de Agua; Coria, 2001), a deinonychosaur (Bajo de Santa Rosa; Novas et al, 2003b), and the Carinatae bird Limenavis patagonica (Salitral Moreno; Clarke \& Chiappe, 2001); the titanosaurids Aeolosaurus sp. (Salitral Moreno; Salgado \& Coria, 1993) and Rocasaurus muniozi (Salitral Moreno; Salgado \& Azpilicueta, 2000); sauropod eggs remains (Powell, 1987c, 1991, 2003); and isolated mammal teeth (Rougier et al., 2003). The vertebrate taxa studied here increase the knowledge of many taxonomic groups of vertebrates for the Allen Formation (see Tables 1-2, and Fig. 21) and provide new data about the vertebrates that inhabited South America during the Campanian-Maastrichtian.

Among the families identified here, specimens of continental (terrestrial and fluvial) and marine environments are documented. Fresh water taxa include Diplomystidae, Percichtyidae, Lepisosteidae, dipnoan lungfishes, pipid frogs, and chelid turtles, whereas terrestrial taxa include madtsoiid snakes, sphenodonts, hadrosaurid, theropod, and titanosaurid dinosaurs. Living leptodactylids inhabit both terrestrial as well as freshwater environments; nevertheless, the closer affinities between the specimens of the Allen Formation and the strictly aquatic living genus Caudiverbera that lives in rivers and streams (Cei, 1962) suggests the presence of another freshwater taxon.

The marine taxa are scarce and fragmentary, and represented by at least one taxon of Elasmosauridae plesiosaur. Within plesiosaurs, this family was interpreted as related to coastal environments (Gasparini et al., 2001); disarticulated remains are frequently found in association with continental vertebrates (e.g., Gasparini \& Salgado, 2000; Gasparini et al., 2001).

Some of the dinosaurs found at Bajo de Santa Rosa are often associated with mixed environments. Hadrosaurids and some sauropods were frequently recovered in coastal marine environments (e.g., shallow marine or estuarial deposits; Horner, 1979; Lucas \& Hunt, 1989; Weishampel \& Horner, 1990; Dodson, 1990; López-Martinez et al, 2000). The two types of eggs (Faveoloolithidae and Megaloolothidae) recorded at Bajo de Santa Rosa have highly porous eggshells; according to Seymour (1979) they must be restricted to a water-satured atmosphere or 


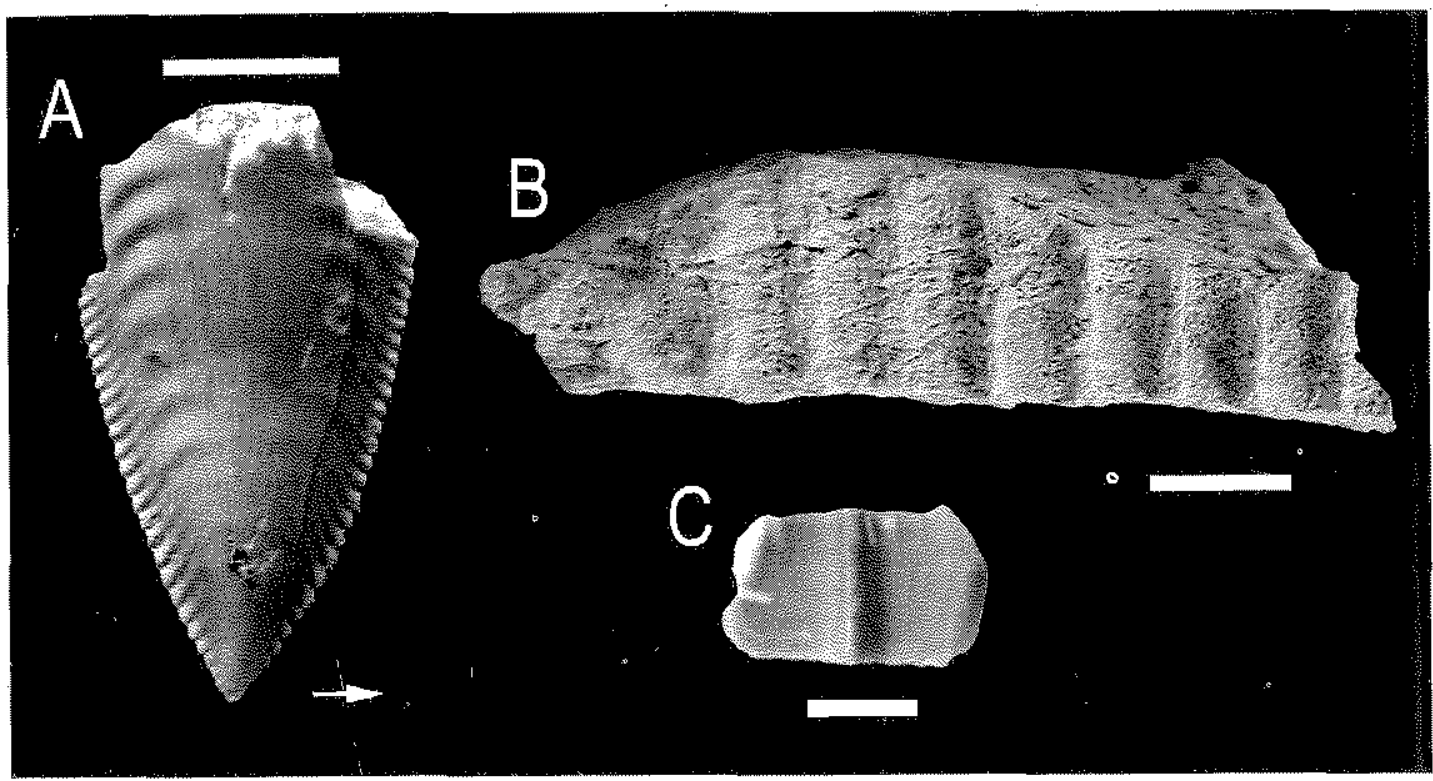

Fig. 20. Theropod. A. MACN-PV RN 1086, tooth of cf. Carcharodontosauridae indet in lingual view (arrow indicates mesial side). Ornithopod. B. MACN-PV RN 1085, fragment of maxilla of Hadrosauridae indet. in lingual view; C. fragment of tooth of Hadrosauridae indet. Scale bar represents $5 \mathrm{~mm}$ in $\mathrm{A}$ and $\mathrm{C}$, and $10 \mathrm{~mm}$ in $\mathrm{B}$.

wetlands (e.g., Seymour, 1979). Megaloolithidae remains were frecuently documented in low mradient floodplain environments in the Río Colorado Subgroup of Neuquén (Dingus et al., 2000) as well as in tidal flats (near sea shore) environment from the Late Campanian of Spain (LopezMartinez et al., 2000). Thus, both types of eggshells indicate a wet and low land environment.

The evidence of the vertebrates presented here collected at Bajo de Santa Rosa is congruent with the paleoenvironmental reconstruction of the Allen Formation based on geological studies: a continental environment developed close to a marginal-litoral place (Andreis et al., 1974; Casamiquela, 1978; Uliana \& Dellapé, 1981 ; Barrio, 1990; Casadío, 1994; González Riga \& Casadio, 2000). This paleoenvironmental reconstruction explains the mixed association of vertebrates composed by terrestrial, freshwater, and marine coastal taxa.

In addition to the vertebrate remains recovered at Bajo de Santa Rosa, fossil wood (Andreis et al., 1991), palm fruit (Ancibor, 1995), and two species of Podocarpaceae conifers (Circoporoxylon gregussii and Podocarpoxylon garciae; Del Fueyo, 1998) in the Allen Formation indicate the presence of a continental environment.

The invertebrate fossils such as gastropod, bivalves, ostracods, briozoans, and foraminifera collected near the Bajo de Santa Rosa, Salitral
Ojo de Agua, Cerro Mesa, Bajo de Los Menucos, and Lago Pellegrini localities suggest fresh water to salty lagoons; whereas the presence of the briozoan Fungela in some localities (Salitral Ojo de Agua and Lago Pellegrini) in to the uppermost level of the Allen Formation (near the contact with the marine Jagüel Formation) indicates marine conditions (Wichmann, 1927; Ballent, 1980; Náñez \& Concheyro, 1996; Echevarría, 1999; Náñez, 1999). As previously mentioned, it is clear that the Allen Formation (and also the Loncoche Formation) represents the transition between the fully continental Neuquén Group and the fully marine Jagüel Formation (Malargüe Group) in northern Patagonia (e.g., Page et al., 1999; and references here cited).

\section{Comments about Campanian- \\ Maastrichtian South American vertebrate- bearing formations}

Most of the vertebrates discovered in the lower member of the Allen Formation represent taxonomic groups of Gondwanan affinities (Bonaparte, 1986b) such as Diplomystidae, Pipidae, Leptodactylidae, Chelidae that during the Cretaceous only inhabited the Patagonian region; Broin \& de la Fuente, 1993), Madtsoidae, cf. Carcharodontosauridae, and Saltasaurinae, and the influence of Laurasic components such as Hadrosauridae and Nodosauridae. This mix- 


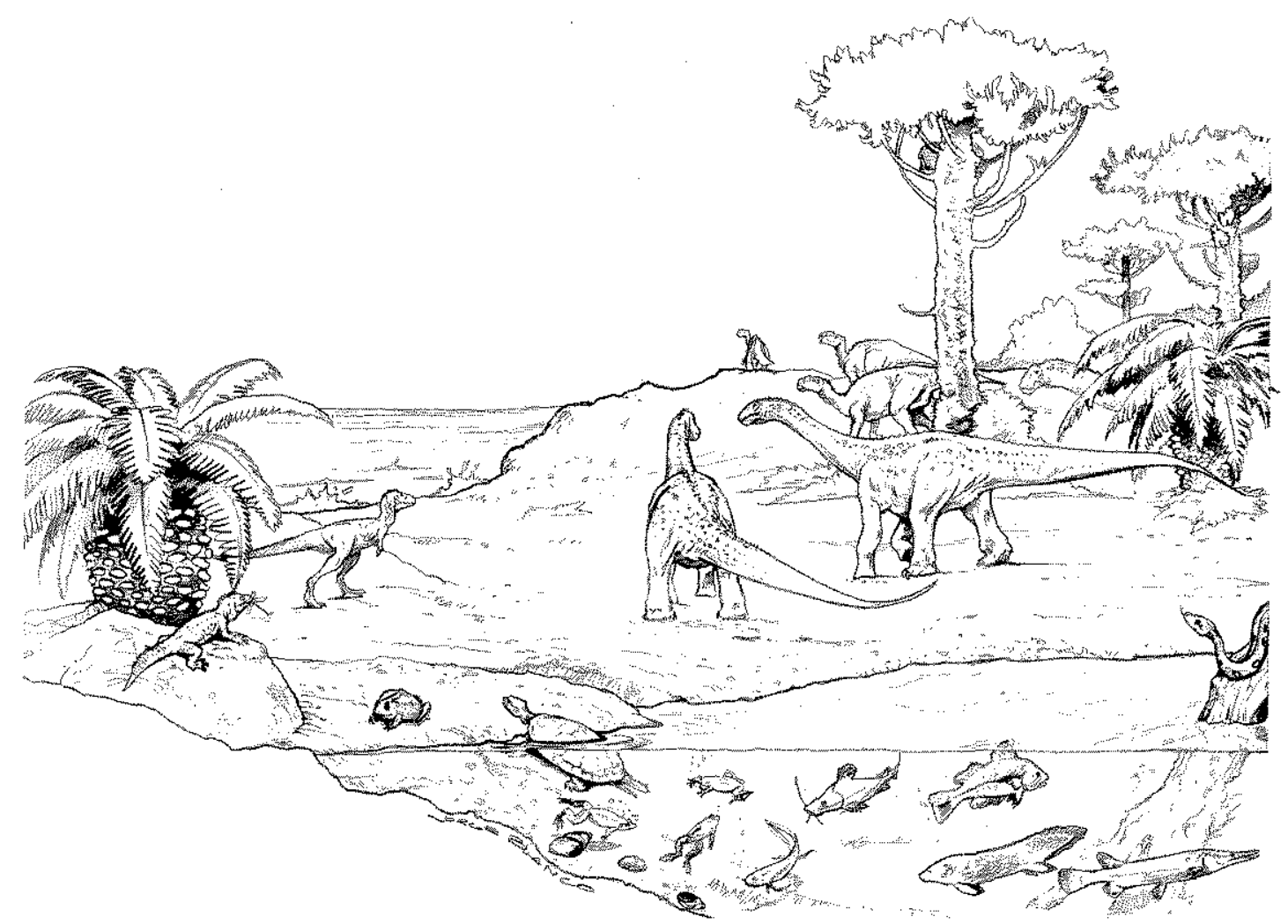

Fig. 21. Squematic reconstruction of the landscape at Bajo de Santa Rosa, Río Negro Province, Argentina, during the Late Cretaceous Allen Formation. Drawing made by Jorge L. Blanco.

ture of taxa has been correlated with the connection between South America and North America through Central America at the end of the Cretaceous (e.g., Anderson \& Schmidt, 1983; Bonaparte, 1986b).

The available evidence from CampanianMaastrichtian vertebrate-bearing formations of South America provide a more complex and diverse vertebrate association than that reported until the present in other Gondwanan localities. The entire information available from several units of South America such as the Loncoche, Los Alamitos, La Colonia, Los Blanquitos, Yacoraite, El Molino, Adamantina, and Marília formations show a similar fossil vertebrate composition, with relatively few differences between the Patagonian and extra Patagonian South Ameri. can records (Table 3 ).

The Loncoche Formation (Late CampanianEarly Maastrichtian) extends over southern Mendoza Province and the west of La Pampa Province. Recent fieldworks provided significantly new vertebrate data (González Riga, 1999). These findings include: Rajiformes, Lepisosteidae, Percoidei, Teleostei, Ceratodontidae, ?Lepto- dactylidae, Chelidae, Plesiosauria, ?Madtsoiidae, Titanosauria, Theropoda, and Hadrosauria.

The Los Alamitos Formation (CampanianMaastrichtian) is exposed over the southeast of Río Negro Province (Bonaparte et al, 1984). The vertebrate assemblage is widely diverse; the taxa recovered include Batoidea, Semionotidae, Lepisosteidae, Siluriformes, Perciformes, and Dipnoi (Cione, 1987); Pipidae and Leptodactylidae (Báez, 1987); Melolanidae and Chelidae (Broin, 1987); Madtsoiidae (Albino, 1986, 1987, 1994); Hadrosauridae (Bonaparte et al., 1984; Bonaparte \& Rougier, 1987); Titanosauridae (Powell, 1987a; Salgado et al., 1997b); and diverse groups of non-tribosphenic mammals (Bonaparte, 1986a, 1987, 1990, 1992, 1994, 2002).

The La Colonia Formation (CampanianMaastrichtian) is exposed in the north-central Chubut Province (Pascual et al., 2000), Fossil vertebrates include Diplomystidae (Bovcon, 2002); Elasmosauridae and Polycotylidae (Gasparini \& de la Fuente, 2000); Meiolanidae and Chelidae (Gasparini \& de la Fuente, 2000); Madtsoidae (Albino, 2000); Crocodyliformes (Hill et al., 2002); Abelisautridae and Hadrosauridae (Bonaparte et 
Table 3. Comparison of the fossil vertebrates of several continental Late Cretaceous Formations of South America. In black are highlight taxa with brackish or marine affinities.

\begin{tabular}{|c|c|c|c|c|c|c|c|}
\hline & woncoche & Allen & $\begin{array}{c}\text { Los } \\
\text { Alamitos }\end{array}$ & $\begin{array}{c}\text { La } \\
\text { Colonia }\end{array}$ & $\begin{array}{c}\text { Salta } \\
\text { Group }\end{array}$ & $\begin{array}{c}\text { El } \\
\text { Molino }\end{array}$ & $\begin{array}{l}\text { Bauru } \\
\text { Group }\end{array}$ \\
\hline Rajiformes & $*$ & & $*$ & & $*$ & $*$ & \\
\hline Chondrichthyes indet. & $*$ & * & * & & * & * & \\
\hline Pyenodontiformes: Pycnodontidae & & & & & * & * & \\
\hline Semionotiformes: Semionotidae & & & * & & & * & \\
\hline Lepisosteiformes: Lepisosteidae & $*$ & $*$ & * & & & * & $*$ \\
\hline Osteoglossiformes: Osteoglossidae & & & & & & $*$ & * \\
\hline Characiformes & & & & & & * & * \\
\hline Siluriformes: Ariidae & & & *? & & & * & \\
\hline Siluriformes: Diplomystidae & & * & * & * & & * & \\
\hline Siluriformes: Andinichthyidae & & & & & & * & \\
\hline Siluriformes: Doradidae & & & & & & & $* ?$ \\
\hline Siluriformes indet. & & * & * & $*$ & * & * & * \\
\hline Perciformes indet. & * & * & * & & & & * \\
\hline Perciformes: Percichthyidae & & $* ?$ & & & & & $*$ ? \\
\hline Dipnoi & $*$ & $*$ & $*$ & $*$ & & $*$ & $*$ \\
\hline Anura: Pipidae & & $*$ & * & & * & & \\
\hline Neobatrachia: Leptodactylidae & *? & * & * & & & * & * \\
\hline Chelonia: Podocnemididae & & & & & & * & * \\
\hline Chelonia: Chelidae & * & * & $*$ & $*$ & & & \\
\hline Chelonia: Meiolanidae & & & * & * & & & \\
\hline Lepidosauriformes: Sphenodontia & & * & $*$ & & & & \\
\hline Plesiosauria: Elasmosauridae & $*$ & $*$ & & * & & & \\
\hline Plesiosauria: Polycotylidae & & & & * & & & \\
\hline Serpentes: Madtsoiidae & $* ?$ & $*$ & $*$ & $*$ & & $*$ & \\
\hline Serpentes: Anilioidea & & & & & & & $*$ \\
\hline Mesoetucrocodylia & & & & $*$ & * & * & $*$ \\
\hline Theropoda: Abelisauroidea & * & $*$ & & $*$ & * & & $*$ \\
\hline Theropoda: Carcharodontosauridae & & $* ?$ & & & & & *? \\
\hline Theropoda: Spinosauridae & & & & & & & * \\
\hline Avialae & & $*$ & & & * & & \\
\hline Sauropoda: Titanosauridae & * & * & * & $*$ & * & $*$ & * \\
\hline Ornithopoda & * & * & * & * & * & * & $*$ \\
\hline Ankylosauria & & * & & & & * & \\
\hline Mammalia: Dryolestoidea & & & * & * & & * & \\
\hline Mammalia; Gondwanatheria & & & $*$ & & & & \\
\hline Mammalia: Multituberculata & & & * & * & & & \\
\hline Mammalia: Eutheria & & & & & & & $* ?$ \\
\hline
\end{tabular}

al., 1990; Hill et al., 2002); and Reigitheridae (Pascual et al., 2000), Dryolestida, and Multituberculata (Rougier et al., 2000, 2001).

Several Campanian-Maastrichtian units (Salta Group) in northwest Argentina have provided continental vertebrate remains. From the Las Curtiembres Formation (Pirgua Subgroup) a Pipidae was described (Reig, 1959; Báez, 1981). From the Los Blanquitos Formation (Pirgua Subgroup) a fragment of titanosaurid (Powell 1979; Powell, 2003) and a maniraptoran (Powell, 1979; Novas \& Agnolin, 2004) were described. From the Yacoraite Formation (Balbuena Subgroup), Rajiformes (Powell, 1979); Siluriformes (Cione 
et al., 1984; Cione \& Pereira, 1985); Pycnodontiformes (Benedetto \& Sánchez, 1971); Eusuchia (Gasparini \& Buffetaut, 1980); and dinosaur and bird tracks (Alonso \& Marquillas, 1986) were reported. From the Lecho Formation (Balbuena Subgroup), Titanosauridae Saltasaturine, Noasauridae, Enantiornithine, a possible oviraptorosaur, and indeterminate nonavian theropod teeth (Bonaparte \& Powell, 1980; Chiappe, 1993; Frankfurt \& Chiappe, 1999) were reported.

The El Molino Formation (Puca Group; Maastrichtian-Danian) extends over the southcenter of Bolivia (Gayet et al., 1991). The vertebrates were broadly described and discussed in several works (e.g. Gayet, 1991; Schultze, 1991a \& b; Gayet \& Meunier, 1998; Gayet et al., 2001, 2003). An overview of all taxa recovered from the El Molino Formation is available in Gayet et al. (1991; 2001 and references; see Table 3).

The Bauru Group represents one of the richest tetrapod assemblages of Upper Cretaceous of Brazil (Turonian to Late Maastrichtian) that extends over the states of Goiás, Mato Grosso do Sul, Minas Gerais, Paraná, and Săo Paulo. In the Adamantina (Turonian-Santonian) and Marilia (Late Maastrichtian) formations many fossil vertebrates were recovered including: Dipnoi, Lepisosteidae, Osteoglossiformes, Characiformes, Perciformes, and Siluriformes (Gayet \& Brito, 1989); Leptodactylidae (Baéz and Perí, 1989); Podocnemididae (e.g., Kischlat et al., 1994); ?Iguania (Estes and Price, 1973); Anilioidea (Zaher et al., 2003); ?Placentaria (Bertini et al., 1993); Mesoeucrocodylia (e.g., Price, 1950; Carvalho \& Bertini, 1999); Abelisauridae (e.g., Bertini, 1996; Santucci \& Bertini, 2001; Kellner \& Campos, 2002); Carcharodontosauridae (Candeiro, 2002); Spinosauridae (Candeiro et al., 2002); and Titanosauridae (e.g., Arid \& Vizzoto, 1971; Kellner and Azevedo, 1999; Powell, 2003).

A preliminary comparison at a supragenerical level suggest strong affinities among the South American vertebrate-bearing units (Table 3). Nevertheless, some taxonomic groups are only restricted to one geographical region; for example Chelidae, Meiolanidae, Sphenodontia, Gondwanatheria, and Multituberculata are until now only recognized in Patagonia. These differences observed in the taxonomic compositon of the ver. tebrate assemblages of Patagonian and extra. Patagonian regions could be artificial due to the insufficient fossil remains recovered in some nonPatagonian fossil localities or it could respond to different paleoenvironmental conditions developed in distant geographical areas.

\section{The case of mammals}

The Mesozoic mammals are a relatively recent group of vertebrates recovered in South America (Bonaparte \& Soria, 1985) that have provided new data about the evolution of the mammalian clades in Gondwana. The richest localities of South America are the CampanianMaastrichtian Los Alamitos and La Colonia formations (e.g., Bonaparte, 1994; Pascual et al., 2000 ); other units (Allen, El Molino, and Adamantina formations) until now only have provided few and isolated remains (Bertini et al., 1993; Gayet et al., 2001; Rougier et al., 2003;). The mammalian Campanian-Maastrichtian record of South America includes: Dryolestoidea (Mesungulatidae, Reigitheridae, and Dryolestidae), Triconodonta, Gondwanatheria, and Multituberculata (e.g., Bonaparte, 1986a, 1987, 1990, 1992, 1994, 2002; Pascual et al., 2000; Rougier et al., 2000, 2003). The mammalian record from the Adamantina Formation consist of a fragmentary lower jaw, which was originally described as a placental mammal (Bertini et al., 1993). Nevertheless, based on the fragmentary nature of the specimen this assignation should be evaluated cautiously.

The Dryolestoidea is at the moment the most diverse and largely documented group of nontribosphenic mammals recognized in several Late Cretaceous localities of South America. Campanian-Maastrichtian Patagonian dryolestoids are widely documented in the Los Alamitos (Bonaparte, 1986a, 1990, 2002) and La Colonia formations (Rougier et al., 2000, 2001), and only a few specimens were recently found in the Allen Formation (Rougier et al., 2003).

Older possible dryolestoid reports from Patagonia come from the Santonian Portezuelo Formation (Neuquén Group; Neuquén Province; Coria et al., 2001; Coria, personal communication); in addition, another specimen originally described as a probable marsupial (Goin et al., 1986) from the Anacleto Formation (Neuquén Group; Paso Córdova, Río Negro Province) could be tentatively assigned to the Dryolestoidea. The jaw of the Paso Córdova specimen is high with the ventral edge slightly convex and transversely rounded, the masseteric fossa is deep, the lingual alveolar level is set notably more ventrally than the lingual one, the alveoli decrease backwards and are transversely wide and very antero"pos" teriorly short resembling the condition of La Colonia dryolestoids (Rougier et al., 2000) and Peligrotherium tropicalis (Bonaparte et al., 1993; Gelfo \& Pascual, 1999) from the Early Paleocene "Banco Negro Inferior" of the Salamanca For- 
mation (Chubut Province, Argentina). These features suggest that the mammal of the Anacleto Formation probably corresponds to a dryolestoid.

Analyses based on the mammalian fossil record of the Los Alamitos and La Colonia formations have considered that they are probably endemic to Patagonia (Enson \& Sigogneau-Russell, 1998; Rougier et al., 2000, 2001). In contrast, Bonaparte (2002), based not only on the record of mammals but also in other vertebrates, criticized this hy. pothesis concluding that the Patagonian mammals are not endemic but a sample of widespread Gondwanan lineages (Bonaparte, 2002). Recent discoveries of mammals with dryolestoid affinities in the Maastrichtian El Molino Formation of Bolivia (Gayet et al., 2001) support the later interpretation.

\section{CONCLUSION}

The vertebrate fossil remains discovered at the Bajo de Santa Rosa locality, Río Negro Prov. ince, Argentina (Table 1 and 2) provide new data about the diversification and compositional vertebrate assemblage of the CampanianMastrichtian Allen Formation (Malargüe Group).

The vertebrates recognized are: chondrichthyans; diplomystid, lepisosteid, cf. percichthyid, and dipnoid osteichthyans; pipid and leptodactylid anurans; chelid turtles; sphenodonts; elasmosaurid plesiosaurs; madtsoiid snakes; faveoolitid and megaloolithid eggshells; and hadrosaurid, cf. carcharodontosaurid and titanosaurid dinosaurs.

Among fishes, the Allen Formation has provided the most southern and possibly the earliest occurrence of Percichthyidae perciforms. The first Campanian-Maastrichtian non-eilenodontid sphenodont and a possible survival carcharodontosaurid theropod are also recognized. The Madtsoiidae are the dominant snakes in the Allen Formation. We recognized Pataganiophis parvus Albino and Alamitophis argentinus Albino, and a possible new taxon of ?Madtsolidae. The taxonomic position of Rionegrophis madtsoioides proposed by Albino $(1986,1987)$ as a possible Madtsoiidae is supported after new discoveries from Los Alamitos. A new saltasaurine titanosaurid, Bonatitan reigi gen. et $\mathrm{sp}$. nov. is described and compared.

The vertebrate record is mainly composed of continental (terrestrial and freshwater) taxa, and a few marine elements (elasmosaurids) indicating the influence of the sea during the deposi- tion of the Allen Formation in the area of Bajo de Santa Rosa.

The vertebrate remains support a Campanian-Maastrichtian age for the Allen Formation. Comparisons with other South American Campanian-Maastrichtian localities suggest a similar fossil vertebrate composition, with relatively few differences between the Patagonian and extra Patagonian South American records.

\section{ACKNOWLEDGEMENTS}

We are deeply indebted to Dr. José F. Bonaparte (MACN) for allow us to study the collection of fossil vertebrates here described and for his continuous advice and discussion on the matter. We gratefully acknowledge to L. Salgado (Universidad Nacional del Comahue, Neuquén), M. S. de la Fuente (Museo Municipal de Historia Natural de San Rafael, Mendoza), R. A. Coria (Museo Municipal «Carmen Funes», Plaza Hiuncul, Neuquén), B. J. González Riga (Centro Regional de Investigaciones Científicas y Técnicas, Mendoza), A. M. Albino (Universidad de Mar del Plata, Buenos Aires), F. E. Novas (MACN), A. LópezArbarello (Museum für Naturkunde Humboldt Universität, Berlin, Germany), A. Báez (Universidad de Buenos Aires, Argentina), A. C. Garrido (Museo Municipal "Carmen Funes», Plaza Hiuncul, Neuquén), M. Gayet (Université Claude Bernard, France), G. W. Rougier (University of Louisville, KY, USA), C. R. A. Candeiro and L. Avilla (Universidad Federal do Rio de Janeiro, Brazil), A. Cambiaso (MACN), S. de Valais and N. Boveon (Museo Paleontológico "Egidio Feruglio", Chubut), and F. Agnolin (MACN) for extended comments on the manuscript. We also want to extend our gratitude to E. R. Paz (MACN) and Y. P. Amarillo (MACN) for their help during the development of the manuscript and the labeling of the collection, and J. Kennedy (University of Louisville, KY, USA) and Y. Gurovich (MACN), for their help in the English corrections. We specially thank J. L. Blanco (MACN) for drawing figure 21. The field works at Bajo de Santa Rosa were directed by Dr. J. F. Bonaparte and supported by the National Geographic Society (USA) and the Centre Studi Ricerche Ligabue (Italy). We thanks R. Vacca (Museo Paleontológico "Egidio Feruglio", Chubut) and M. P. Isasi (MACN) for collecting and/ or preparing fossils during field works. Finally, we specially thanks F. E. Novas, B. J. González Riga, A. Roig-Alsina (MACN), and Y. Gurovich (MACN) for their assistence in the last version of the Ms. 


\section{BIBLIOGRAPHY}

Albino, A. M. 1986. Nuevos Boidae Madtsoinae en el Cretácico tardío de Patagonia (Formación laos Alamitos, Río Negro, Argentina). Actas IV Cong. Argent. Paleont, y Bioest. 2: 15-21.

- 1987. The Ophidians. In: J. F. Bonaparte (ed.), The Late Cretaceous fauna from Los Alamitos, pp. 1.11. 146, Revista del Museo Argentino de Ciencias Naturales (Paleontología) 3 .

- 1990. Los serpientes de Sao José de Itaboraí (Edad Itaboraiense, paleoceno medio), Brasil. Ameghiniana 27 : $337-342$.

- 1994. Una nueva serpiente (Reptilia) del Cretácico superior de Patagonia, Argentina. Pesquisas 21: 58* 63.

- 1996. The South American fossil Squamata (Reptilia: Lepidosauria). In: Arratia G. F (ed.), Contribution of sourthern. South America to Vertebrate Paleontology (A) 30, pp 9-72. Münchner Geowissenschaftliche Abhandlungen, München.

- 2000. New record of snakes from the Cretaceous of Patagonia (Argentina). Geodiversitas 22: 247-253.

Alcober, O., P. C. Sereno, H. C. F. Larsson, R. Martinez \& D. J. Varricchio. 1998. A Late Cretaceous carcharodontosaurid (Theropoda: Allosauroidea) from Argentina. \%. Vert. Paleont. 18 (suppl. to 3): $23 \mathrm{~A}$.

Alonso, R. N. \& R. A. Marquillas. 1986. Nueva localidad con huellas de dinosaurios y primer hallazgo de huellas de aves en la Formación Yacoraite (Maastrichtiano) del norte Argentino. Actas IV Cong. Argent. Paleont. y Bioest. 2: 33-41.

Ameghino, F. 1899. Sinopsis geológico-paleontológica de la Argentina. Segundo Censo Nacional de la República Argentina. Suplemento (adiciones y correcciones): 1.13, La Plata.

Ancibor, E. 1995. Palmeras fósiles del Cretácico tardío de la Patagonia Argentina (Bajo de Santa Rosa, Río Negro\}, Ameghiniana 32 (3): 287-299.

Anderson, T. H. \& V. A. Schmidt. 1983. The evolution of Middle America and the Gulf of MexicomCaribbean Sea region during Mesozoic time. Bull. Geol. Sc. Am. 94: 941-966.

Andreis, R. R., A. M. Iñiguez Rodríguez, J. J. Lluch \& D. A. Sabio. 1974. Estudio sedimentológico de las formaciones del Cretácico Superior del área del Lago Pellegrini (Brov. de Rio Negro, Rep. Argen. tina). Rev, Asoc. Geol. Argent. 29:84-104.

Andreis, R. R., E. Ancibor, S. Archangelsky, A. Artabe, J. E.Bonaparte \& J. Genise. 1991. Asociación de vegetales y animales en estratos del Cretácico tardío del Norte de Patagonia. Ameghiniana 28 (1. 2): $201-204$.

Apesteguía, S. \& A. Cambiaso. 1999. Hallazgo de hadrosaurios en la Formación Paso del Sapo (Campaniano-Maastrichtiano, Chubut): otra localidad del «Senoniano Lacustre». Ameghiniana 36 (4, Supl. Resúmenes): $5 \mathrm{R}$.

Apesteguia, S. \& F. E. Novas. 2003. Large Cretaceous sphenodontian from Patagonia provides insight into lepidosaur evolution in Gondwana. Nature 425: $609-612$.

Arambourg, C. \& L. Joleaud. 1943. Vertébrés fossiles du Bassin du Niger. Bull. Mines, Gouvern. A. O.F. 7: 1-74. PI. I-V.

Ardolino, A. \& M. Franchi. 1996. Telsen. Hoja Geológica 4366 I. Provincia de Chubut. Bol. Dir. Nac. Serv. Geol. 215: 7.110 .

Arid, F.M. \& L. D. Vizzoto. 1971. Antaretosaurus brasiliensis, um novo saurópodo do Cretáceo Superior do sul do Brasil. XXV Congr. Brasileiro Geol. (São Paulo) 1: 297-305.

Arratia, G. F 1982. A review of freswater percoids from South America (Pisces, Osteichthyes, Perciformes, Percichthyidae and Percilidae). Abhandlungen de Senchembergischen Naturforschenden Gesellschaft, Frankfurt 540: 1.52.

Arratia, G. F \& A. L. Cione. 1996. The record of fossil fishes of southern South America. In: Arratia G. F. (ed.), Contribution of sourthern South America to Vertebrate Paleontology, pp. 9-72, (A) 30. Münchner Geowissenschaftiche Abhandlungen, München.

Astibia, H., E. Buffetat, A. D. Buscalioni, H. Cappetta, C. Corral, R. Estes, F. Garcia-Garmilla, J. J. Jaeger, E. Jimenez-Fuentes, J. Le Loeuf, J. M. Mazin, X. Orue-Etxebarria, J. Pereda-Suberbiola, J. E. Powel, J. -C. Rage, J. Rodriguez-Lazaro, J. L. Sanz \& H. Tong. 1990. The fossil vertebrates from Laño (Bosque Country, Spain); new evidence on the composition and affinities of the Late Cretaceous continental faunas of Europe. Terra Nova 2: 460-466.

Báez, A. M. 1977. Sobre Teracophrys (Anura, Leptodactylidae) Nomina Nuda, de la Formación Colhue-Huapi (Oligoceno Superior) (Provincia del Chubut; Republica Argentina. Rev. Asoc. Geol. Ar gent. 32 (2); $145-151$.

- 1981. Redescription and relationships of Saltenia ibanezi, a late Cretaceous pipid frog from northwestern Argentina. Ameghiniana 3-4: 127-154.

- 1987. Anurans. In: J. F. Bonaparte (ed.), The Late Cretaceous fauna from Los Alamitos, pp. 121-130, Revista del Museo Argentino de Ciencias Naturales (Paleontologia) 3.

1991. A new Early Paleocene neobatrachian frog from the Santa lucia Formation in South Central Bolivia, and comments on the Cretaceous and Early Tertiary batrachofaunas of South America. In: Suarez-Soruco, R. (ed.). Fósiles y facies de Bolivia, pp. 529-440, Vol. 1 Vertebrados, Revista Técnica de YPFB 12.

- 1995. Estesiella, replacement name for Estesius, a Paleocene neobatrachian frog from Bolivia. Ameghiniana 32: 56.

1996. The fossil record of the Pipidae. In: R. C. Tinsley and H. R. Kobel (eds.), The Biology of Xenopus, pp. 329-327, Zoological Society of London. Oxford, Clarendon Press.

Báez, A. M. \& S. Perí. 1989. Baurubatrachus pricei, nov. gen. et sp., un anuro del Cretácico Superior de Minas Gerais, Brasil. An. Acad. Bras. Ci. 61(4): 447458.

Báez, A. M. \& L. Trueb, 1997. Redescription of the Paleogene Shelania pascuali from Patagania and its bearing on the relationships of fossil and recent pipoid frogs. Mus. Nat. Hist. Univ. Kansas, Scient. Paper 4: 1-41.

Báez, A. M. \& I. A. Púgener. 1998. A new Paleocene 
pipid frog from northwestern Patagonia. J. Vert. Paleont. 18: 511-524.

Báez, A. M. \& L. A. Púgener. 2003. Ontogeny of a new Palaeocene pipid frog from southern South America and xenopodinomorph evolution. Zool. J. Linn. Soc. 139: $439-476$.

Báer, A. M. L. Trueb \& J. O. Calvo. 2000. The earliest known pipoid frog from South America: A new genus from the Middle Cretaceous of Argentina. of Vert. Paleont. 20: 490-500.

Ballent, S. 1980. Ostrácodos de ambiente salobre de la Formación Allen (Cretácico Superior) en la Provincia de Río Negro, Republica Argentina. Ameghiniand 17 (1): 67-82.

Barrio, C. A. 1990. Paleogeographic control of Upper Cretaceous tidal deposits, Neuquén Basin, Argen* tina. I. South Am. Earth Sci. 3 (1): $31-49$.

Benedetto, J. \& T. Sánchez. 1971. El hallazgo de peres Pycnonodontiformes (Holostei) en la Formación Yacoraite (Cretácico superior) de la provincia de Salta. Ameghiniana 9 (1): 59-71.

Berman, D. S.\& J, S. McIntosh, 1978. Skull and relationships of the Upper Jurassic sauropod Apatosaurus (Reptilia, Satrischia). Bull. Carnegie Mus. NaL. Hist. 8: I-35.

Berman, D. S. \& S, L. Jain. 1982. The braincase of a small sauropod dinosaur (Reptilia: Saurischia) from the Upper Cretaceous Lameta Group, central India, with review of Lameta Group localities. Ann. Carnegie Mus. Nat. Hist, 51: 405-422.

Bertels, M. 1964. Micropaleontología del Paleoceno de General Roca (Prov. de Río Negro). Rev. Mus. La Plata, Nieva Serie 4, Paleont. 23: 125-184.

- 1969. Micropaleontologia y estratigrafía del límite Cretácico-Terciario en Huantraico, Provincia de Neuquén, Parte II. Ameghiniana 7 (1): 1-56.

Bertini, R. J. 1996. Evidêcias de Abelisauridae (Carnosauria: Saurischia) do Neocretáceo da Bacia do Paraná. Bol. $4^{\circ}$ Simp. Cret, Bras. 1996: 267-271.

Bertini, R. J., L. G. Marshall, M. Gayet \& P. Brito. 1993. Vertebrate faunas from the Adamantina and Marilia formations (Upper Baurú Group, Late Crè taceous, Brazil) in their stratigraphic and paleobiogeographic context. $N$. Jb. Geol. Paläont. Abh. 188: 71-101.

Bittencourt, J. de S. \& A. W. A. Kellner. 2002 Abelisauria (Theropoda, Dinosauria) teeth from Brazil, Bol. Mus. N. S. Geol., Rio de Janeiro 63: 18.

Bona, P., G. Cladera \& M. de la Fuente, 1998. Las tortugas pleurodiras de la Formación Salamanca (Paleoceno Inferior) en el área de Cerro Hansen, provincia de Chubut, Argentina. Actas $X$ Cong. Latinoamericano Geol. y VI Cong. Nac. Geol. Econ. 1: $269 \cdot 274$.

Bonaparte, J. F. 1986a. Sobre Mesungulatum houssayi y nuevos mámíferos Cretácicos de Patagonia, Ar. gentina. Actas IV Cong. Argent. Paleont. y Bioest. 2: 48-61.

- 1986b. History of the terrestrial Cretaceous vertebrate of Gondwana. Actas IV Cong. Argent. Paleont. y Bioest. 2: 63-95.

1987. The mammals. In: J. F. Bonaparte (ed.), The Late Cretaceous fauna from Los Alamitos, pp. 163.
169, Revista del Museo Argentino de Ciencias Naturales (Paleontología) 3.

1990. New Late Cretaceous mammals from the Los Alamitos Formation, Norther Patagonia. Nat. Geogr: Research 6: 63-93.

1991. Los vertebrados fósiles de la Formación Río Colorado, de la Ciudad de Neuquén y cercanías, Cretácico Superior, Argentina. Rev. Mus. Argent. Ci. Natur. 4: 1.7-123.

- 1992. Una nueva especie de Triconodonta (Mammalia), de la Formación Los Alamitos, Provincia de Río Negro y comentarios sobre su fauna de mamíferos. Ameghiniana 29 (2): 99-110.

- 1994. Approach to the significance of the Late Cretaceous mammals of South America. Berliner Geowiss Abh. E 13: 31-44.

- 1996. Cretaceous tetrapods of Argentina. In: Arratia G. F. (ed.), Contribution of sourthern South America to Vertebrate Paleontology, pp. 73-130, Münchner Geowissenschaftliche Abhandlungen (A) 30, München.

1999. Evolución de las vértebras presacras en Sauropodomorpha. Ameghiniana 36:115-187.

- 2002. New Dryolestida (Theria) from the Late Cretaceous of Los Alamitos, Argentina, and paleogeographical comments. N. Jb. Geol. Paläont. Abh 224 (3): $339-371$.

Bonaparte, J.F. \& Z. B. Gasparini. 1978. Los saurópodos de los Grupos Neuquén y Chubut, y sus relaciones cronológicas. Actas V Cong. Geol. Argent. 2: 393406.

Bonaparte J. F. \& . E. Powell. 1980. A continental assemblage of tetrapods from the Upper Cretaceous beds of El Brete, northwestern Argentina (Sauropoda, Coelurosauria, Carnosauria, Aves). Mémoires Soc. Géol. France 139: 19-28.

Bonaparte, J. F. \& M. F. Soria, 1985. Nota sobre el primer mamífero del Cretácico Argentino, Campaniano-Maastrichtiano (Condylarthra). Ameghiniana $21(2-4): 177-183$.

Bonaparte, J. F, M. R. Franchi, J. E. Powell \& E. C. Sepulveda, 1984. La Formación Los Alamitos (Campaniano-Maastrichtiano) del sudeste de Río Negro, con descripción de Kritosaurus australis nov. sp. (Hadrosauridae). Significado paleogeográfico de los vertebrados. Rev. Asoc. Geol. Argent. 39: 284299.

Bonaparte, J. F. \& F. E. Novas. 1985. Abelisaurus comahuensis, n. g. n.sp., Carnosauria del Cretácico Tardio de Patagonia. Ameghiniana 21: 259-265.

Bonaparte, J. F. \& G. W. Rougier. 1987. The hadrosaurs. In: J. F. Bonaparte (ed.), The Late Cretaceous fauna from Los Alamitos, pp. 155-161, Revista del Museo Argentino de Ciencias Naturales (Paleontología) 3 .

Bonaparte, J. F., F. E. Novas \& R. A. Coria. 1990. Carnotaurus sastrei Bonaparte, the horned, lightly built carnosaur from the Middle Cretaceous of Patagonia. Contr. Sci., Nat. Hist. Mus. Los Angeles Country 416: 1.42.

Bonaparte, J. F. \& R. A. Coria. 1993. Un nuevo y gigantesco saurópodo Titanosaurio de la Formación Río Limay (Albiano-Cenomaniano) de la provincia del Neuquén, Argentina. Ameghiniana 30: 271-282.

Bonaparte, J. F., L. M. Van Valen \& A. Kramarz. 1993. 
La fauna local de Punta Peligro, Paleoceno Inferior, de la provincia de Chubut, Patagonia, Argen tina. Evolutionary Monographs 14: 1-61.

Borsuk-Byalinicka, M. 1977. A new camarasaurid sauropod Opisthocoelicaudia skarzynskit gen. n. sp. n. from the Upper Cretaceous of Mongolia. Palaeontologia Polonica 37: 5-64.

Bovcon, N. D. 2002. Espinas pectorales de Siluriformes de la Formación La Colonia (Cretácico Superior). Ameghiniana 39 (4, Suppl. Resúm.): 7.

Broin, F. de. 1987. Chelonia. In: J. F. Bonaparte (ed.), The Late Cretaceous fauna from Los Alamitos, pp. 131-139, Revista del Museo Argentino de Ciencias Naturales (Paleontologia) 3.

- 1991. Fossil turtles from Bolivia. In: Suarez-Soruco, R. (Ed.). Fósiles y facies de Bolivia, pp. 509-527, Vol. 1 Vertebrados, Revista Técnica de YPFB 12.

Broin, F. de \& M. S. de la Fuente. 1993. Les tortues fossiles d'Argentine: Synthése. Ann. Paléont. 79: 169-232.

Caldwell, M. W. \& A. Albino. 2002. Exceptionally preserved skeletons of the Cretaceous snake Dinilysia patagonica Woodward, 1901. J. Vert. Paleont. 22: $861-866$.

Calvo, J. O. 1994. Jaw mechanics in sauropod dinosaurs. Gaia 10: 183-194.

Calvo, J. O. \& J. F. Bonaparte. 1991. Andesaurus delgadoi n.g.n.sp. (Saurischia, Sauropoda) dinosaurio Titanosauridae de la Formación Río Limay (Albiano-Cenomaniano), Neuquén, Argen* tina. Ameghiniana 28: 303-310.

Calvo, J. O. \& L. Salgado. 1995. Rebbachisaurus tessonei sp. nov, a new Sauropoda from the AlbianCenomanian of Argentina: new evidence on the origin of the Diplodocidae. Gaia 11: 13-33.

Calvo, J. O., R. A. Coria \& L. Salgado. 1997a. Uno de los más cornpletos titanosáuridos (DinosauriaSamropoda) registrados en el mundo. Ameghiniana $34(4): 534$.

Calvo, J. O., S. Engelland, S. E. Heredia \& L. Salgado. $1997 \mathrm{~b}$. First record of dinosaur eggshells (?Sauropoda-Megaloolithidae) from Neuquén, Patagonia, Argentina. Gaic 14: 23-32.

Candeiro, C. R. A. 2002. [Dentes de Theropoda da Formaçăo Marilia (Santoniano-Maastrichtiano), Bacia Bauru, região de Peirópolis, Minas Cerais, Brasil. Dissertaçáo de Mestrado, Dep. de Geologia, Universidade Federal do Rio de Janeiro, 126 pp. Unpublished.)

Candeiro, C. R. A., S. Torres, A. Moreira, V. Martins, E. Abrantes, L. Ávilla, C. Abranches \& L. Bergqvist. 2002. Novos achados de Dinosauria no oeste de São Paulo, na Formaçăo Adamantina (Bacia Bauru), Cretáceo superior. II Simp. Cret. America del Sur, Bol. Res, Rio Claro, UNESP: $409-413$.

Carvalho, 1.S. \& R.J. Bertini. 1999. Mariliasuchus, um novo Crocadylomorpha (Notosuchia) do Cretáceo da Bacia Bauru, Brasil. Geol. Colombiana 24: 83-105.

Casadío, S. A. 1994. [Estratigrafia y Paleontología del intervalo Maastrichtiano-Daniano en el occidente de la Provincia de La Pampa, Argentina. PhD, Facultad de Ciencias Exactas, Físicas y Naturales, Universidad Nacional de Córdoba. Pp. 353. Unpub. lished.]
Casadío, S. A., T. Manera, A. Parras \& C. I. Montalvo. 2002. Huevos de dinosaurios (Faveoloolithidae) del Crétacico Superior de la cuenca del Colorado, provincia de la Pampa, Argentina. Ameghiniana 39 (3): $285-293$

Casamiquela, R. M. 1958. Un anuro gigante del Mioceno de la Patagonia. Rev. Asoc. Geol. Argent, 13 (3-4): 55.63 .

- 1969. La presencia en Chile de Aristonectes Cabrera (Plesiosauria), del Maastrichtense del Chubut, Ar" gentina. Edad y carácter de la transgresión "Rocanense". Actas IV Jorn. Geol. Argent. 1. 199. 213.

- 1978. La zona litoral de la transgresión Maastrichtense en el norte de Patagonia. Aspectos ecológicos. Ameghiniana 15: 137-148.

Cannatella, D. C. \& L. Trueb. 1988. Evolution of pipoid frogs: intergeneric relationships of the aquatic frog family Pipidae (Anura). Zool. J. Linnean Soc. 94: $1-38$.

Cei, J. M. 1962. Batracios de Chile. Ediciones de la Universidad de Chile. Pp. 128 and Lamines.

Chiappe, L. M. 1993. Enantiornithine (Aves) Tarsometatarsi from the Cretaceous Lecho Formation of Northwestern Argentina. Am. Mus. Novit. 3083 : $1-27$.

Chiappe, L. M., R. A. Coria, L. Dingus, F Jackson, A. Chinsamy \& M. Fox. 1998. Sauropod dinosaur embryos from the Late Cretaceous of Patagonia. $\mathrm{Na}$ ture 396: 258-261.

Cione, A. L. 1987. The fishes. In: J. F. Bonaparte (ed.), The Late Cretaceous fauna from Los Alamitos., pp. 111-120, Revista del Museo Argentino de Ciencias Naturales (Paleontología) 3.

Cione, A. L. \& G. Laffite. 1980. El primer siluriforme (Pisces, Ostariophysi) del Cretácico de Patagonia. Consideraciones sobre el área de diferenciación de los Siluriformes. Aspectos biogeográficos. Actas II Cong. Argent. Paeont. y Bioest, y I Cong. Latinoamericano Paleont. (1978, Buenos Aires) 2: $35-46$.

Cione, A. L., S. M. Pereira, R. Alonso \& J. Arias, 1984. Los bagres (Osteichthyes, Siluriformes) de la Formación Yacoraite (Cretácico Tardío) del Noroeste argentino. Consideraciones biogeográficas y bioestratigráficas. Ameghiniana 21: 294-304.

Cione, A. L. \& S. M. Pereira. 1985. Los peces de la Formación Yacoraite (Cretácico Tardio-Terciario, Noroeste Argentina) como indicadores de salinidad. Rev. Asoc. Geol. Argent. 40: 294-304.

Cione, A. L. \& G. V. R. Prasad. 2002. The oldest known catfish (Teleostei; Siluriformes) from Asia (India, Late Cretaceous). J. Paleont. 76 (1): 190-193.

Clarke, J. A. \& L. M. Chiappe. 2001. A new carinate bird from the Late Cretaceous of Patagonia (Argentina). Am. Mus. Novit. 3323: 1-23.

Coira, B. L. 1979. Descripción geológica de la Hoja 40d, Ingeniero Jacobacci, provincia de Río Negro. Bol. Serv. Geol. Nac. 168p.

Concheyro, A., C. Náñez \& S. Casadío. 2002. El límite Cretácico.Paleógeno en Trapalcó, provincia de Río Negro, Argentina, Euna localidad clave en América del Sur?. Actas XV Congr. Geol. Arg. El Calafate 1: 590-595. 
Coria, R. A. 2001. New theropod dinosaur from the Late Cretaceous of Patagonia. In: Tanke, D. H. \& Car penter, K. (eds.), Mesozoic Vertebrate Life, pp. 3-9, Bloomington/Indianapolis: Indiana University Press.

Coria, R. A. \& L. Salgado. 1995. A new giant carnivorous dinosaur from the Cretaceous of Patagonia. Nature 377:224-226.

- 1999. Nuevos aportes a la anatomía craneana de los saurópodos titanosáuridos. Ameghiniana 36 (4 Supl. Resúm.); 98.

- 2001. South America ankilosaurs. In: K. Carpenter (ed.), The armored dinosqurs, pp. 159-168, In* diana University Press.

Coria, R. A., P. J. Currie, D. Eberth, A. Garrido \& E. Koppelhus. 2001. Nuevos vertebrados fósiles del Cretácico Superior de Neuquén. Ameghiniana 38 (4, Supl. Resúm.): 6.

Coria, R. A., L. Chiappe \& L. Dingus. 2002. A new close relative of Carnotatrus sastrei Bonaparte 1985 (Theropoda: Abelisauridae) from the Late Cretaceous of Patagonia. J. Vert. Paleont. 22: 460-465.

Currie, P. J., K. Jr. Rigby \& R. E. Sloan. 1990. Theropod teeth from the Judith River Formation of southern Alberta, Canada. In: Carpenter, $\mathrm{K}$. and Currie, P.J. (eds.), Dinosaurs Systematics: Approaches and Perspecives, pp. 107-125, London, Cambridge Uni versity Press, 750pp.

Curry Rogers, K. \& C. A. Forster. 2001. The last of the dinosaurs titans: a new sauropod from Madagas. car. Noture 412: 530-534.

- 2004. The skull of Rapetosaurus krausei (Sauropoda: Titanosauria) from the Late Cretaceous of Madagascar. J. Vert. Paleont. 24: 121-144.

Depéret, C. 1896. Sur l'existence de dinosauriens sauropodes et théropodes dans le Crétacé supérieur de Madagascar. C. R. Acad. Sci., Paris 122: 483-485.

De Beer, G. R. 1937. The development of the vertebrate shull. Oxford University Press, London. $552 \mathrm{pp}$.

de la Fuente, M. S. 1993 . Un posible Podocnemididae (Pleuriodira: Pelomedusoides) en el Cretácico Tardio de la Patagonia. Implicaciones paleobiogeográficas. Ameghiniana 30: 423-433.

- 2003. Two new pleurodiran turtles from the Portezuelo Formation (Upper Cretaceous) of Northern Patagonia, Argentina. J. Paleont. 77 (3); $559 \sim 575$.

de la Fuente, M. S., F. de Lapparent de Broin \& T. Manera de Bianco. 2001. The oldest and first nearly complete skeleton of a chelid, of the Hydromedusa subgroup (Chelidae, Pleurodira), from the Upper Cretaceous of Patagonia. Bull. Soc. Géol. France 172: 237-244.

de la Peña, A. D. \& R. Soler-Gijón. 1995. The first siluriform fish from the Cretaceous-Tertiary boundery interval of Eurasia. Lethaia 28: 345-346.

de Valais, S. \& S. Apesteguía. 2001. Dientes asignables a Giganotosaurus (Carcharodontosauria, Theropoda) provinientes de "La Buitrera", Formación Candeleros, provincia de Río Negro, Ameghiniana 38 (4, Supl. Resúm.): 6-7.

Del Fueyo, G. M. 1998. Coniferous woods from the Upper Cretaceous of Patagonia. Rev. Españ. Paleont. 13 (1): 43-50.
Dingus, L., J. Clarke, G. R. Scott, C. C. Swisher III, L. M. Chiape \& R. A. Coria. 2000. Stratigraphy and magnetostratigraphic/faunal constraints for the age of sauropod embryo-bearing rocks in the Neuquén Group (Late Cretaceous, Neuquén Province, Argentina). Am. Mus. Nov. 3290: 1-11.

Dodson, P. 1990. Sauropod paleoecology, In: D. B. Weishampel, P. Dobson, and H. Osmólska (eds.). The Dinosauria, pp. 402+407, University of California Press, Berkeley and Los Angeles.

Duellman, W. E. \& L. Trueb. 1986. Biology of amphib ians. McGraw. Hill Book Company, New York, St. Louis and San Francisco. Pp. 670.

Echevarria, A. 1999. Informe paleontológico (Ostrácodos) de las muestras de la Hoja 3966-III Vila Regina, Provincia de Río Negro. Serv. Geol. Min. Argent, SEGEMAR (inédito). Buenos Aires.

Ensom, P.C. \& Sigogneau-Russell, D. 1998. New dryolestoid mammals from the basal Cretaceous Purbeck Limestone Group of Southern England. Palcueontology $41: 35-55$.

Estes, R. 1975. Xenopus from the Paleocene of Brazil and its zoogeographic importance. Nature 254: 48-50.

1977. Relationships of the South African fossil frog Eoxenopoides reuningi (Anura, Pipidae). Ann. South Afr. Mus. 73: 49-80.

Estes, R. \& L.I. Price. 1973. Iguanid lizard from the Upper Cretaceous of Brazil. Science 180: 748-751.

Evans, S. E. \& D. Sigogneau-Russell. 1997. New sphenodontians (Diapsida:- Lepidosauromorpha: Rhynchocephalia) from the early Cretaceous of North America. J. Vert. Paleont. 17: 45-51.

Evans, S. E., G. V. R. Prasad \& B. K. Manhas. 2001. Rhynchocephalians (Diapsida: Lepidosauria) from the Jurassic Kota Formation of India. Zool. J. Linnean Soc. 133: 309-334,

Ferigolo, J. 2000. Esfenodontídeos do Neomtriássico/ ?Jurássico do Estado do Rio Grande do Sul, Brasil. In: M. Holz and L. F. De Ros (eds.), Paleontologia do Rio Grande do Sul, pp, 236-245, CIGO/UFRGS Porto Alegre.

Ford, L. S. \& D. C. Cannatella. 1993. The major clades of frogs. Herpetological Monographs 7: 94-117.

Frankfurt, N. G. \& L. M. Chiappe. 1999. A possible oviraptorosaur from the Late Cretaceous of Northwestern Argentina. J. Vert. Paleont. 19(1): $101-105$.

Fraser, N. C. \& M. J. Benton. 1989. The Triassic reptiles Brachyrhinodon and Polysphenodon and the relationships of the sphenodontids. Zool. J. Linnean Soc. 96: 413-445.

Frizzel, D. \& J. Koenig. 1973. Upper Cretaceous ostariophysine (Vorhisia) redescribed from unique association of utricular and lagenar otoliths (lapillus and asteriscus). Copeia 1973: 692-698.

Gaffney, E. S. 1983. Cranial morphology of the extinct horned turtle, Meiolania platyceps, from the Pleis. tocene of Lord Howe Island, Australia. Bull. Am. Mus. Nat. Hist. 175: 361-480.

- 1996. The posteranial morphology of Meiolania platyceps and a review of the Melolanidae. Bull. Am. Mus. Nat. Hist, 229: 1-166.

Galton, P. M. 1985. Cranial anatomy of the prosauropod dinosaur Plateosaurus from the Knollenmergel 
(Middle Keuper, Upper Triassic) of Germany. Geologica et Palaeontologica 19:119.159, 6Pls.

- 1989. Cranial and endocranial casts from ornithopod dinosaurs of the families Dryosauridae and Hysilophodontidae (Reptilia: Ornithischia). Geologica et Palaeontologica 23: 217\%239, 4Pls.

Gasparini, Z. \& E. Buffetaut. 1980. Dolichochampsa minima, n. g., n. sp., a representative of a new fam. ily of eusuchian crocodiles from the Late Cretaceous of northern Argentina. N. Jb. Geol. Paläont. Abh. 1980: 257-271.

Gasparini, Z. \& R. Goñi. 1985. Los plesiosaurios Cretácicos de América del Sur y del continente Antártico. Actas VII Cong. Bras. Paleont., 1993. Coletanea de Trabalhos Paleont., Série Geol. 27: 55-63.

Gasparini, Z. \& L. Spalletti. 1993. First Callovian plesiosaurs from the Neuquen basin, Argentina. Ameghiniana 30 (3): 245-254.

Gasparini, Z. \& L. Salgado. 2000. Elasmósauridos (plesiosauria) del Cretácico Tardío del Norte de Patagonia, Rev. Españ. Paleont. 15: 13-21.

Gasparini, Z. \& M. de la Fuente. 2000. Tortugas y Plesiosaurios de la Formación La Colonia (Cretácico Superior) de la Patagonia, Argentina. Rev. Españ. Paleont. 15: 23-35.

Gasparini, Z., S. Casadío, M. Fernández \& L. Salgado. 2001. Marine reptiles from the Late Cretaceous of northern Patagonia. J. S. Am. Earth Sc. 14:51-60.

Gasparini, Z, N. Bardet, J. E. Martin \& M. Fernandez. 2003 a. The elasmosaurid plesiosaurs Aristonectes Cabrera from the Latest Cretaceous of South America and Antarctica. J. Vert. Paleont, 23(1): 104. 115.

Gasparini, Z., L. Salgado \& S. Casadío. 2003b. Maastrichtian plesiosaurs from northern Patagonia. Cret. Research 24: 157-170.

Gayet, M. 1987. Lower vertebrates from the Early. Middle Eocene Kuldana Formation of Kahat $(\mathrm{Pa}-$ kistan): Holostei and Teleostei. Contr. Mus. Paleont, Uniu. Michigan 27: 151-168.

- 1991. "Holostean» and Teleostean fishes of Bolivia. In: Suarez-Soruco, R. (ed.). Fósiles y facies de Bolivia, pp. 453-494, Vol. 1 Vertebrados. Revista Téenica de YPFB 12 .

Gayet, M. \& P. Brito. 1989. Ichthyofaune nouvelle du Crétacé supérieur du Groupe Baurú (Etats de Sao Păulo et Minas Gerais, Brésil). Geobios 22: 841-847.

Gayet, M., L. G. Marshall \& T. Sempere. 1991. The Mesozoic and Paleocene vertebrates of Bolivia and their stratigraphic context: a review. In: SuarezSoruco, R. (ed.). Fósiles y facies de Bolivia, pp. 393433, Vol. 1 Vertebrados. Revista Técnica de YPFB 12.

Gayet, M. \& F. J. Meunier. 1998. Maastrichtian to Early Late Paleocene freshwater Osteichthyes of Bolivia: Additions and Comments. In: Malabarba, L.R., R.E. Reis, R.P. Vari, Z.M. Lucena \& C.A.S. Lucena (eds.), Phylogeny and Classification of Neotropical Fishes, pp. 85-110.

Gayet, M., L. G. Marshall, T. Sempere, F. t. Meunier, H. Cappetta \& I. C. Rage. 2001. Middle Maastrichtian vertebrates (fishes, amphibians, dinosaurs and other reptiles, mammals) from Pajcha Pata (Bolivia). Bio- stratigraphic, palaeoecologic and palaeobiogeographic implications. Palaeogeography, Palaeoclimatology, Palaeoecology 169: 39-68.

Gayet, M., M. Jégu, J. Bocquentin \& F. R. Negri. 2003. New characoids from the Upper Cretaceous and Paleocene of Bolivia and the Mio-Pliocene of Bra. zil: phylogenetic position and paleobiogeographic implications. d. Vert. Paleont. 23 (1): 28-46.

Gauthier, J., R. Estes \& K. de Queiroz. 1988. A phylogenetic analysis of Lepidosauromorpha. In: Phylo genetic relationships of the lizard families, essays commemorating C. L. Camp, Stanford, California, Stanford University Press, pp. 15 48 .

Gelfo, J. N. \& R. Pascual. 2001. Peligrotherium tropicalis (Mammalia, Dryolestida) from the early Paleocene of Patagonia, a survival from a Mesozoic Gondwanan radiation. Geodiversitas 23 (3): 369-379.

Gilmore, C. W. 1922. A new sauropod dinosaur from the Ojo Alamo Formation of New Mexico. Smith. Misc. Collect. $72(14): 1-9$.

- 1946. Reptilian fauna of the North Horn Formam tion. U. S. Geol. Surv. 210C: 1-15.

Gomani, E. M., H. L. Jacobs \& D. A. Winkler. 1999. Comparison of the African titanosaurian Malawisaurus, with a North American Early Cretaceous sauropod. In: Y. Tomida, T. H. Rich and P. Vickers-Rich (eds.), Proceedings of the Second Gondwanan Dinosaur Symposium (Tokyo), pp. 223. 233, National Science Museum Monographs 15.

Goin, F. J., A. A. Carlini \& R. Pascual. 1986. Un probable marsupial del Cretácico Tardio del norte de Patagonia, Argentina. Actas IV Cong. Argent. Paeont. y Bioest. 2: 43-47.

González Riga, B. J. 1999. Hallazgo de vertebrados fósiles en la Formación Loncoche, Cretácico Superior de la provincia de Mendoza, Argentina. Ameghiniana 36: 401-410.

- 2003. A new titanosaur (Dinosauria, Sauropoda) from the Upper Cretaceous of Mendoza Province, Argentina. Ameghiniana 40: 155-172.

González Riga, B. J.\& S. Casadío. 2000. Primer registro de Dinosauria (Omithischia, Hadrosauridae) en la provincia de la Pampa (Argentina) y sus implicancias paleobiogeográficas. Ameghiniana 37 : $341-351$.

Gottfried, M. D. \& D. W. Krause, 1998. First record of gars (Lepisosteidae, Actinopterygii) on Madagascar: Late Cretaceous remains from the Mahajunga Basin. J. Vert. Paleont. 18: 275-279.

Henrici, A. C. \& A. M. Báez. 2001. First occurrence of Xenopus (Anura: Pipidae) on the Arabian Peninsula: a new species from the Upper Oligocene of Yemen. J. Paleont. 75 (4): 870-882.

Heredia, S. \& L. Salgado. 1999. Posición estratigáfica de los estratos supracretácicos portadores de dinosaurios en Lago Pellegrini, Patagonia septentrional, Argentina, Ameghiniana 36: 229234.

Hill, R. V., D. Pol, G. W. Rougier, P. Muzzopappa \& P. Puerta. 2002. New dinosaur fossils from the Late Cretaceous La Colonia Formation, Chubut Province, Argentina. J. Vert. Paleont. 22 (3) (Suppl. Abstract): 65 . 
Hoffstetter, R. 1961. Nouveaux restes d'un serpent boïdé (Madtsoia madagascariensis nov. sp.) dans le Crétacé supérieur de Magagascar. Bull. Mus. Nat. Hist. Nat. 33:152-160.

Horner, J. R. 1979. Upper Cretaceous dinosaurs from the Bearpaw Shale (marine) of South-Central Montana, with a checklist of upper Cretaceous dinosaur remains from marine sediments in North America. J. Paleont. 53: 566-577.

Hubbs, C. L. \& C. W. Hibbard. 1951. Ictalurus lambda, a new catfish based on a pectoral spine from the lower Pliocene of Kansas. Copeia 1951: 8-14.

Huene, Fv von. 1929. Los saurisquios y ornitisquios del Cretaceo Argentino. An. Mus. La Plata (Serie 2) 3: $1-196$.

Huene, F. von. \& C. A. Matley. 1933. The Cretaceous Saurischia and Ornithischia of the central prov* inces of India. Mem. Geol. Surv. India. 21(1): 1-74, Delhi.

Hugo, C. A. \& H. A. Leanza. 2001. Hoja Geológica 3966III, Villa Regina. Provincia de Río Negro. Instituto de Geología y Recursos Minerales, Servicio Geológico Minero Argentino. Bolentin, $53 \mathrm{pp}$. Buenos Aires.

Jacobs, L. L, D. A. Winkler, W. R. Downs \& E. M. Gomani. 1993. New material of an Early Cretaceous titanosaurid sauropod dinosaur from Malawi. $\mathrm{Pa}$ leontology 36: 523-534.

Jain, S. L. \& S. Bandyopadhyay. 1997. New titanosaurid (Dinosauria: Sauropoda) from the Late Cretaceous of Central India. J. Vert. Paleont. 17: 114-136.

Janensch, W. 1935-36. Die schadel der Sauropoden Brachioscurus, Barosaurus und Dicraeosaurus aus den Tendaguruschichten Deustch-Ostafrikas. Palaeontographica (suppl.) 2: 147-298.

- 1950. Die Wirbelsäule von Brachiosaurus brancai. Palaeontographica 7: 27-93.

Kellner, A. W. A., \& Azevedo, S. A. K. de. 1999. A new sauropod dinosaur (Titanosauria) from the Late Cretaceous of Brazil. Im: Y. Tomida, T. H. Rich and P. Vickers-Rich (eds.), Proceedings of the Second Gondwanan Dinosaur Symposium (Tokyo), pp. 111. 142, National Science Museum Monographs 15.

Kellner, A. W. A. \& D. de A. Campos. 2002. On a theropod dinosaur (Abelisauria) from the continental Cretaceous of Brazil. Arquiv. Mus. Nac., Rio de Janeiro 60 (3): 163-170.

Kemp, A. 1983. Ceratodus nargun, a new Early Cretaceous ceratodont lungfish from Caoe Lewis, Victoria. Proc. Royal Soc. Victoria. 95: 23-24. 1997. Four species of Metaceratodus (Osteichthyes: Dipnoi, Family Ceratodontidae) from the Australian Mesozoic and Cenozoic deposits. J. Vert. Paleont. 17 (1): 26-33.

Kischlat, E. E., M. C. Barberena \& L. L.Timm. 1994. Consideraçóes sobre a queloniofauna do Grupo Bauru, Neocretáceo do Brasil. II Simpósio sobre o Cretáceo do Brasil (Rio Claro, Brasil), Abstracts, pp. 105-107.

Kobel, H. R., C. Loumont \& R. C. Tinsley. 1996. The extant species. In: R. C. Tinsley and H. R. Kobel (eds.), The Biology of Xenopus, pp. 9-33, Zoological Society of London. Oxford, Clarendon Press.

Krause, D. W., G. V. R. Prasad, W. von Koenigswald, A.
Sahni \& F. Grine. 1997. Cosmopolitanism among Gondwanan Late Cretaceous mammals. Nature 390: $504-507$.

Krause, D. W., R. R. Rogers, C. A. Forster, J. H. Hartman, G. A. Buckley \& S. D. Sampson. 1999. The Late Cretaceous vertebrate fauna of Madagascar: implication for Gondwanan paleobiogeography. GSA Today 9: 1\%7.

Kurzanov, S. M. \& A. F. Bannikov. 1983. A new sauropod from the Upper Cretaceous of Mongolia. Paleontologicheskyy Zhurnal 1983: 91-97.

Lapparent de Broin, F, M. de la Fuente \& J. Calvo. 1997. Presencia de los más antiguos quélidos (tortugas pleurodiras) en el Cretácico Inferior de El Chocón, provincia del Neuquén, Argentina. Ameghiniana 34: 538.

Lapparent de Broin, F. \& M. de la Fuente. 2001. Oldest world Chelidae (Chelonii, Pleurodira), from the Cretaceous of Patagonia. C. R. Acad. Sci. Paris 333: $463-470$.

Larsson, H. C. E. 1996. Cranial morphology of the African theropod, Carcharodontosaurus salvaritus (Allosauroidea). J. Vert. Paleont. 16 (3) (Suppl. Abstract): 47 .

Lazo, D. G. \& M. Cichowolski. 2003. First plesiosaur remains from the Lower Cretaceous of the Neuquen Basin, Argentina. J. Paleont. 77: 784-789.

Legarreta, L. \& C. A. Gulisano. 1989. Análisis estratigráfico secuencial de la Cuenca Neuquina (Triásico Superior - Terciario Inferior). Cuencas Sedimentarias Argentinas 1989: 221-243.

Le loeuff, J. 1993. European titanosaurids. Revue de Paléobiologie 7: 105-117.

- 1995. Ampelosaurus atacis (nov. gen., nov. sp.), un nouveau Titanosauridae (Dinosauria, Sauropoda) du Crétacé supérieur de la Haute vallée de l'Aude (France), C. R. Acad. Sci., Sér. Ila 321: 693\#699.

Le Loeuff, J., E. Buffetaut, P. Mechin \& A. Mechin* Salessy. 1989. Un arrière-crâne de dinosaure titanosauridé (Saurischia, Sauropoda) dans le Crétacé supérieur du Var (Provence, France). C. R. Acad. Sci. Paris 309: 851-857.

López-Arbarello, A., G. F. Arratia \& M. A. Tunik. 2003. Saldenioichthys remotus gen. et sp. nov. (Teleostei, Perciformes) and other acanthomorph remains from the Maastrichtian Saldeño Formation (Mendoza, Argentina). Mitt. Mus. Nat. Kd. Berl., Geowiss. Reihe 6: 161.172.

López-Martinez, N., J. J. Moratalla \& J. L. Sanz, 2000. Dinosaurs nesting on tidal flats. Palaeogeography, Palaeoclimatology, Palaeoecology 160: 153-163.

Lucas, S. G. \& A. P. Hant. 1989. Alamosaurus and the sauropod hiatus in the Cretaceous of North American Western Interior. Geol. Soc. Amer, Spec. Paper 238: 75-85.

Lydekker, R. 1877. Notice of new and other Vertebrata from Indian Tertiary and Secondary rocks, $R$. Geol. Surv. India 10: 30-43.

- 1879. Indian pre-Tertiary Vertebrata. The Reptilia and Batrachia. Palaeontologia Indica 1 (4): 1-36. 1887. On certain dinosaur vertebrae from the Cre-

t taceous of India and the Isle of Wight. Quart. J. Geol. Soc. London 43: 156-160.

1893. Contributions to the study of the fossil ver- 
tebrates of Argentina. I: The dinosaurs of Patagonia: An. Mus. La Plata 2: 1-14.

Lynch, J. D. 1971. Evolutionary relationships, osteology and zoogeography of leptodactyloid frogs. Mus. Nat. Hist. Univ. Kansas Mis. Pub. 53: 1-238.

Madsen, J. H., J. S. Mclntosh \& D. S. Berman. 1995. Skull and atlas-axis complex of the Upper Jurassic sauropod Camarasaurus Cope (Reptilia: Saurischia). Bull. Carnegie Mus. Nat. Hist. 31: 1-115.

Martin, M. 1982. Nouvelles données sur la phylogénie et la systématique des Dipneustes postpaléozoîques, conséquences stratigraphiques et paléogégraphiques. Geobios, mêmoire spécial 6: 53-64.

Martin, M., L. Barbieri \& G. Cuny, 1999. The madagascan Mesozoic ptychoceratodontids (Dipnoi), systematic relationships and paleotiogeographical significance. Oryctos 2: 3-16.

Martinez, R. 1998. An articulated skull and neck of Sauropoda (Dinosauria: Saurischia) from the Up. per Cretaceous of Central Patagonia, Argentina. $d$. Vert. Paleont. 18 (3): 61A.

Mclntosh, J. S. 1990. Sauropoda. In: D. B. Weishampel, P. Dobson, and H. Osmólska, (eds.), The Dinosauria, pp. 345-401, University of California Press, Berkeley and Los Angeles.

Meylan, P. A. 1996. Skeletal morphology and relationship of the early Cretaceous side-necked turtle, Araripemys barretoi (testudines: Pelomedusoides: Araripemydidae), from the Santana Formation of Brazil. J. Vert. Paleont. 16: 20-33.

Mikhailov, K. E. 1991. Classification of fossil eggshells of amniotic vertebrates. Acta Paleont. Pol. 36: $193-238$.

Molnar, R. E. 1989. Terrestrial tetrapods in Cretaceous Antarctica. In: J. A. Crame (ed.), Origins and evolution of the Antarctic Biota, pp. 131-140, Geological Society Special Publication 47.

Mones, A. 1980. Nuevos elementos de la paleoherpetofauna del Uruguay (Crocodylia y Dinosauria). Actas $\|$ Cong. Argent. Paleont. $y$ Bioest. y I Cong. Latinoamericano Paleont. (Buenos Aires) 1: 265-277.

- 1997. Los vertebrados mesozoicos del Uruguay y sus relaciones con los de áreas vecina. In: J. Arroyo Cabrales and O. e. Polaco (eds.), Homenaje al Professor Ticul Alvarez, pp. 205-222, Colección Cientifica, Instituto Nacional de Antropología e Historia, México, 357.

Muizon, C. de, M. Gayet, A. Lavenu, L. G. Marshall, B. Sigé \& C. Vilarroel. 1983. Late Cretaceous vertebrates including mammals from Tiupampa, southcentral Bolivia. Geobios 16: 747-753.

Náñez, C. 1999. Informe micropaleontológico sobre muestras de la Hoja 3966-III, Villa Regina. Serv. Geol. Min. Argent. SEGEMAR (inédito). Buenos Aires.

Náñez, C. \& A. Concheyro. 1996. Límite CretácicoPaleogeno. In: A. Ardolino \& M. Franchi (eds.), Geología y Recursos Minerates del Departamento Añelo, Provincia de Neuquén. Republica Argentina. Anales Dirección Nacional del Servicio Geológico, 25, 129+149. Buenos Aires.

Novas, F. F., R. D. Martinez, S. de Valais \& A. Ambrosio. 1999. Nuevos registros de Carcharodontosauridae
(Dinosauria, Theropoda) en el Cretácico de Patagonia. Ameghiniana 36 (4, Supl. Resúm.): 17.

Novas, F. E., \& S. de Valais. 2001. Preliminary study of possible carcharodontosaurids (Dinosauria, Theropoda) from the Cerro Barcino Formation, Chubut Province. Ameghiniana 38 (4, Supl. Resúm.): 14-15.

Novas, F.E., M. Fernández, Z. B. de Gasparini, H. J. Núnez \& P. Puerta. 2003a. Lakumasaurus antarcticus $\mathrm{n}$. gen. et sp., a new mosasaur (Reptilia, Squamata) from the Upper Cretaceous of Antarctica. Ameghiniana 39: 245-249.

Novas, F. E., J. I. Canale \& M. P. Isasi. 2003b. Un terópodo maniraptor del Campaniano-Maas. trichtiano del Norte patagónico. Ameghiniana 40 (4, Supl. Resúm.): 63.

Novas, F. E. \& F. L. Agnolin. 2004. Unquillosaurus ceibali Powell, a giant maniraptoran (Dinosauria, Theropoda) from the Late Cretaceous of Argentina. Rev. Mus. Arg. Ciene. Nat. «B. Rivadavia», n.s., 6 (1): $61-66$.

Nowinski, A. 1971. Nemegtosaurus mongoliensis n. gen., n. sp., (Sauropoda) from the Uppermost Cretaceous of Mongolia. Palaeont. Polonica 25: 57-81.

Olivero, E.B., Z. B. de Gasparini, C. A. Rinaldi \& R. A. Scasso. 1991. First record of dinosaurs in Antaretica (Upper Cretaceous, James Ross Island): paleogeographical implication. In: M.R.A. Thomson, J.A. Crame, and J.W.Thomson (eds.), Geological Evolution of Antarctica, Cambridge University Press, pp. $617-622$.

Page, R., A. Ardolino, R. E. Barrio, M. Franchi, A. Lizuain, S. Page \& D. Silva Nieto. 1999. Estratigrafía del Jurásico y Cretácico del Masizo de Somún-Curá, Provincias de Río Negro y Chubut. In: Caminos R. (ed.), Geologia Argentina, pp. 460488, Segemar Anales 29.

Pascual, R. \& P. Bondesio. 1976. Notas sobre vertebrados de la frontera Cretácica-Terciaria. III: Ceratodontidae (Peces, Osteichthyes, Dipnoi) de la Formación Coli-Toro y de otras unidades del Cretácico Tardío de Patagonia y sur de Mendoza. Sus implicancias paleobiogeográficas. Actas VI Cong. Geol. Argent. 1: 565-577.

Pascual, R., F. J. Goin, P. Gonź́lez, A. Ardolino \& P. Puerta. 2000. A highly derived docodont from the Patagonian Late Cretaceous: evolutionary implications for Gondwanan mammals. Geodiversitas 22: $395-414$.

Patterson, C. 1993. Osteichthyes: Teleostei. In: M. J. Benton (ed.), The Fossil Record 2, pp. 622-656, Chapman and Hall, London.

Powell, J. E. 1979. Sobre una asociación y otras evidencias de vertebrados del Cretácico superior de la región de la Candelaria, prov, de Salta, Argentina. Ameghiniana 16 (1-2): 191-204.

1986. [Revisión de los Titanosáuridos de América del Sur. Ph.D. dissertation (unpublished). Universidad Nacional de Tucumán, Facultad de Ciencias Naturales, Argentina, 493 pp.]

1987a. The titanosaurids. In: J. F. Bonaparte (ed.), The Late Cretaceous fauna from Los Alamitos, pp. 147-153, Revista del Museo Argentino de Ciencias Naturales (Paleontología) 3. 
- 1987b. Hallazgo de un dinosaurio hadrosaurio (Ornithischia-Ornithopoda) en la Formación Allen (Cretácico Superior) de Salitral Moreno, Prov. de Río Negro, Argentina Actas X Cong. Geol. Argent. 3: 149-152.

- $1987 \mathrm{c}$. Nuevas evidencias de huevos de dinosaurios en el Cretácico Superior, Salitral Ojo de Agua, provincia de Río Negro, Argentina. Resúmenes IV J. Argent. Paleont. Vert. (Comodoro Rivadavia): 8-9.

- 1991. Hallazgo de huevos asignables a dinosaurios Titanosauridae (Saurischia, Sauropoda) de la provincia de Río Negro, Argentina. Acta Zool. Lilloana 41: 381.394.

- 1992. Osteología de Saltasaurus loricatus (Sauropoda-Titanosauridae) del Cretácico Superior del noroeste argentino. In: J. L. Sanz and A. D. Buscalioni, (eds.) Los Dinosaurios y su entorno biótico, pp. 165-230, Actas del Segundo Curso de Paleontologia en Crenca, Instituto «uan de Valdés", Cuenca, Spain.

1994. First record of dinosaur eggs in the Upper Cretaceous of northwestern Argentina. VI Cong. Argent, Paleont. y Biostrat., Symposium: Gondwana dinosaurs: Phylogeny and Biogeography (Trelew), Abstract: 1.

- 2003. Revision of South American titanosaurid dinosaurs: palaeobiological, palaeobiogeographical and phylogenetic aspects. R. Queen Victoria Mus. 111: 1-173.

Price, L. I. 1950. Os crocodilideos da fauna da formaçäo Baurú, do Cretáceo terrestre do Brasil Meridional. An. Acad. Bras. Ci. 22 (4): $473-490$.

Price, 1. 1. 1951. Un ovo de dinosaurio na formaçao Bauru do Cretácico do Estado de Minas Gerais. Pub. Dep. Nac. Prod. Min., Div. Geologia e Mineria, Notas Preliminares e Estudos 53: 1-9.

Priem, F. 1924. Paléontologie de Madagascar. XII. Les poissons fossiles. Ann. Paléont 13, 197-132.

Rage, J.-C. 1987. Fossil history. In: R.A. Seigel, Collins and S.S. Novak (eds.), Snakes. Ecology and Evolutionary Biology, pp. 51-76, MacMillan, New York.

- 1996. Les Madtsoidae (Reptilia, Serpentes) du Crétacé Supérieur d'Europe: témoins gondwaniens d'une dispersion transtéthysienne. C. R. Acad. Sci. Paris 322: 602-608.

- 1998. Fossil snakes from the Paleocene of Säo José de Itaborai, Brazil. Part I. Madtsoiidae, Aniliidae. Palaeovertebrata 27: 109-144.

- 1999. Squamates (Reptilia) from the Upper Cretaceous of Laño (Bosque Country, Spain). Est. Mus. Cienc. Nat. Alava 14 (Nro. Espec. 1): 121-133.

- 2001. Fossil snakes from the Paleocene of São José de Itaboraí, Brazil. Part II. Boidae. Palaeovertebrata 30: $111-150$.

Rage, J.-C. \& A. Albino. 1989. Dinilysia patagonica (Reptilia, Serpentes): matériel vertébral additionnel du Crétacé supérieur d'Argentine. Etude complémentaire des vertébres, variations intraspécifiques et intracolumnaires. Geol. Palaont. Mh: $433-447$

Reig, O. 1959. Primeros datos descriptivos sobre los anuros del Eocretáceo de la provincia de Salta (Rep. Argentina). Ameghiniana 1: 1-8.
Reynoso, V. H. 1997. A 'beaded'sphenodontian (Diapsida: Lepidosauria) from the Early Cretaceous of central Mexico.J. Vert. Paleont. 17: 52-59.

- 2000. An unusual aquatic sphenodontian (Reptilia: Diapsida) from the Tlayua Formation (Albian), Central Mexico. J. Paleont. 74: 133-148.

Rich, T. H., P. Vickers-Rich \& R. A. Gangloff. 2002. Polar dinosaurs. Science 295: 979-980.

Rieppel, O., A. G. Kluge \& H. Zaher. 2002. Testing the phylogenetic relationships of the Pleistocene snake Wonambi naracoortensis Smith. J. Vert. Paleont. 22: $812-829$.

Rougier, G. W. M. J. Novacek, R. Pascual, J. N. Gelfo \& G. Cladera. 2000. New Late Cretaceous mammals from Argentina and the survival of Mesozoic lineages in the Patagonian Early Tertiary. d. Vert. Paleont. 20 (Suppl. to number 3): 65A.

Rougier, G. W., M. J. Novacek, R. Pascual, R. V. Hill, E. Ortiz-Jaureguizar \& P. Puerta. 2001. Mammalian petrosals from the Late Cretaceous of South America: Implications for the evolution of the mam. malian ear region. J. Vert. Paleont. 21 (Suppl. to number 3): 94-95.

Rougier, G. W. A. G. Martinelli \& A. M. Forasiepi. 2003. The Mesozoic mammalian record in South America: a reappraisal. 2003 Seatlle Annual Meeting, Terrestrial Paleobiology of South America, Cretaceous through Neogene. Abstract.

Salgado, L. 1996. Pellegrinisaurus powelli nov. gen. et sp. (Sauropoda, Titanosauridae) from the Upper Cretaceous of Lago Pellegrini, northwestern Patagonia, Argentina. Ameghiniana 33: 355-365.

- 2003. Should We abandon the name Titanosauridae? Some comments on the taxonomy of titanosaurian sauropods (Dinosatria). Rev, Espan. Paleont. $18(1): 13-20$.

Salgado, L. \& J. O. Calvo. 1992. Cranial osteology of Amargasaurus cazaui Salgado and Bonaparte (Sauropoda-Dicraeosauridae) from the Neocomian of Patagonia. Ameghiniana 29: 337-346.

Salgado, L. \& R. A. Coria. 1993. El género Aeolosaurus (Sauropodam Titanosauridae) en la Formación Allen (Campaniano Maastrichtiano) de la provincia de Río Negro, Argentina. Ameghiniana 30: 119-128.

Salgado, L. \& R. A. Coria. 1996. First evidencia of an ankylosaur (Dinosauria, Ornithischia) in South America. Ameghiniana 33: 367-371.

Salgado, L. \& J. O. Calvo. 1997. Evolution of titanosaurid sauropods. II: The cranial evidence. Ameghiniana 34: 33-48.

Salgado, L., R. A. Coria \& J. O. Calvo. 1997 a. Evolution of titanosaurid sauropods. I: Phylogenetic analysis based on the postcraneal evidence. Ameghiniana $34: 3.32$.

Salgado, L., R. A. Coria \& J. O, Calvo. 1997b. Presencia del género Aeolosaurus (Sauropoda, Titano. sauridae) en la Formación Los Alamitos, Cretácico Superior de la Provincia de Río Negro, Argentina. Geociencias II (6): 44-49.

Salgado, L. \& C, Azpilicueta. 2000. Un nuevo saltasaurino (Sauropoda, Titanosauridae) de la provincta de Río Negro (Formación Allen, Cretácico Superior), Patagonia, Argentina. Ameghiniana 37: 259-264. 
Sampson, S. D., L. M. Witmer, C. A. Forster, D. W. Krause, P. M. O'Connor, P. Dodson \& F. Ravoavy. 1998. Predatory dinosaur remains from Madagas. car: implications for the Cretaceous biogeography of Gondwana. Science 280: 1048-1041.

Santucci, R. M. \& R. J. Bertini. 2001. Distribuiçäo paleogeográfica e biocronológica dos titanosauros (Saurischia, Savropoda) do Grupo Bauru, Cretáceo Superior do Sudeste Brasileiro. Rev. Brasil. Geocienc. 31: 307-314.

Sanz, J. L., J. E. Powell, J. Le Loeuf, R. Martinez \& X. Pereda Suberbiola. 1999. Sauropod remains from the Upper Cretaceous of Laño (Northcentral Spain). Titanosaur phylogenetic relationships. Est. Mus. Cienc. Nai. Alcwa 14 (Nro. Espec. 1):235-255.

Scanlon, J. D. 1992. A new large madtsoiid snake from the Miocene of the northern territory. $R$. Northern Territory Mus. Arts Sci. 9(1): 49.60 .

- 1993. Madtsoiid snakes from the Eocene Thingamarra Fauna of eastern Queensland. Kaupia $3: 3-8$.

Scanlon, J. D. \& M. S. Y. Lee. 2000. The Pleistocene serpent Wonambi and the early evolution of snakes. Nature 403: 416-420.

Schaeffer, B. 1947. Cretaceous Tertiary actinopterygian fishes from Brazil. Bull. Am. Mus. Nat. Hist. 89: 7-39.

- 1949. Anuran from the early Tertiary of Patagonia. Bull. Am. Mus. Nat. Hist. 93: 41-68.

Schultze, H.-P. 1991a. Lungfish from the El Molino (Late Cretaceous) and Santa Lucia (Early Paleocene) Formations in southcentral Bolivia. In: Suarez-Soruco, R. (ed.). Fósiles y facies de Bolivia, pp 441-448, Vol. 1. Vertebrados. Revista T'écnica de YPFB 12.

- 199lb. Pycnodont fish (Actinopterygii, Os. teichthyes) from the El Molino, Late Cretaceous of Bolivia. In: Suarez.-Soruco, R. (ed.). Fósiles y facies de Bolivia, pp. 449-452, Vol. 1 Vertebrados. Revista Técnica de YTFB 12.

Sereno, P. C. 1998. A rationale for phylogenetic definitions, with application to the higher-lever taxonomy of Dinosauria. N. Jb. Geol. Paläont. Abh. 210:41-83.

Sereno, P. C., D. B. Dutheil, M. lorochene, H. C. E. Larsson, G. H. Lyon, P. M. Magwene, C. A. Sidor, D. J. Varricchio \& J. A. Wilson. 1996. Predatory dinosaurs from the Sahara and the Late Cretaceous faunal differentiation. Science 272: 986-991.

Seymour, R. S. 1979. Dinosaur eggs: gas conductance through the shell, water loss during incubation and clutch size. Paleobiology 5: 1-11.

Sigé, B. 1968. Dents de micromammifères et fragments de coquilles d'oeufs de dinosauriens dans la faune de vertébrés du Crétacé supérieur de Laguna Umayo (Andes péruviennes). C. R. Acad. Sci. Paris 267: 1495-1498.

Sigé, B., A. D. Buscalioni, S. Duffaud, M. Gayet, B. Orth, J.-C. Rage \& J. L. Sanz. 1997. Etat des données sur le gisement Crétacé supérieur continental de Champ-Garimond (Gard, Sud de la France). Münchner Geowiss. Abh (A) 34: 11..130.

Silva, J. S. da. 1990. Paleontología de la Formación TYacuarembó (Uruguay). Resúmenes Ampliados I Congr. Urug. Geol. (Montevideo) 2: 27-31.
Silva, VG. da \& de Azevedo, S. A. K. 1992. Um dipnóico da Formacảo Brejo Santo, Jurássico da Chapada do Araripe, Ceará, Brasil. An. Acad. Bras. Ci. 64 (4): $419 m 420$.

Simón, M. E. \& Kellner, A. W. A. 2003. New sphenodontid (Lepidosauria, Rhynchocephalia, Eilenodontinae) from the Candeleros Formation, Cenomanian of Patagonia, Argentina. Bol. Mus. N. S., Geol., Rio de Janeiro 68: 1-12.

Smith, J. B., M. C. Lamanna, K. J. Lacovara, P. Dodson, J. R. Smith, J. C. Poole, R. Giegengack \& Y. Attia. 2001. A giant sauropod dinosaur from an Upper Cretaceous mangrove deposit in Egypt. Science 292: $1704-1706$.

Sues, H-D., N. H. Shubin \& P. E. Olsen. 1994. A new sphenodontian (Lepidosauria: Rhynchocephalia) from the McCoy Brook Formation (Lower Jurassic) of Nova Scotia, Canada. J. Vert. Paleont. 14: $327-340$.

Sues, H-D. \& R. R. Reisz. 1995. First record of the early Mesozoic sphenodontian Clevosaurus (Lepidosauria: Rhynchocephalia) from the Southern Hemisphere. . Paleont. 69: 123-126.

Staesche, K. von. 1937. Podocnemis brasiliensis n. $\mathrm{sp}$. aus der Oberen Kreide Brasiliens. $N$. $J b$. Geol. Paläont. Abh, 77: 291-309.

Taquet, P. 1976. Géologie et Paléontologie du gisement de Gadoufaoua (Aptien du Niger). Cashiers de Paléontologie, Editions du Centre National de la Recherche Scientifique: 1-191. PIs. I-XXIV.

Tinsley, R. C., C. Loumont \& H. R. Kobel. 1996. Geo* graphical distribution and ecology. In: R. C. Tinsley and H. R. Kobel (eds.), The Biology of Xenopus, pp. 35-59, Zoological Society of London. Oxford, Clarendon Press.

Uliana, M. A. \& D. A. Dellapé. 1981. Estratigrafia y evolución paleoambiental de la sucesión Maastrichtiano-Eoterciaria del engolfamiento neuquino (Patagonia septentrional). Actas VIII Cong. Geol. Argent. 3:673-711.

Upchurch, R. 1995. The evolutionary history of sauropod dinosaurs. Phit. Trans. Royal Soc. London B 349: $365-390$.

- 1998. The phylogenetic relationships of sauropod dinosaurs. Zool. J. Linnean Soc. 124: 43-103.

1999. The phylogenethic relationships of the Nemegtosauridae (Saurischia, Sauropoda). J. Vert. Paleont. 19: 106-125.

Vickers-Rich R, T. H. Rich, D. R. Lanus, L.. S. Rich \& R. Vacca. 1999. "Big tooth" from the Early Cretaceous of Chubut Province, Patagonia: a possible carcharodontosaurid. In: Tomida Y., Rich T. \& Vickers Rich P (eds.), Proceedings of the Second Gondwanan Dinosaur Symposium, pp. 85-88, Na. tional Science Museum Monographs, Tokio 15.

Vilas-Boas, I., I. S. Carvalho, M. A. Medeiros \& H. Pontes. 1999. Dentes de Carcharodontosaurus (Dinosauria, Tyrannosauridae) do Cenomaniano, Bacia de Säo Luis (Norte do Brasil). An. Acad. Bras. Ci. $71(4): 846-847$.

Weishampel, D. B. \& J. R. Horner. 1990. Hadrosauridae. In: D. B. Weishampel, P. Dobson, and H. Osmólska (eds.), The Dinosauria, Pp. 534-561, University of California Press, Berkeley and Los Angeles. 
Weishampel, D. B., D. D. Grigorescu \& D. B. Norman. 1991. The dinosaurs of Transylvania. Nat. Geogr. Research 7: 477-494.

Welles, S. P 1943. Elasmosaurid plesiosaurs with description of new materials from California and Colorado. Univ. Calif., Memoirs Geol. Sci. 13: 125-254.

- 1952. A review of the North American Cretaceous elasmosaurs. Univ. Calif, Public. Geol. Sci. 29:47. 144.

Wenz, S. 1969. Note sur quelques poissons actinoptérygiens de Crétacé supérieur de Bolivie. Bull. Soc. Géol. France 11: 434-438.

Wenz, S. \& P. Brito. 1992. Première découverte de Lepisosteidae (Pisces, Actinopterygii) dans le Crétacé inférieur de la Chapada do Araripe (N-E du Brésill). Conséquences sur la phylogénie des Ginglymodi. C. R. Acad. Ci. Paris 308 (II): 975980.

White, T. E. 1958. The braincase of Camarasaurus lentus (Marsh). J. Paleont. 32: 477-494.

Wichmann, R. 1924. Nuevas observaciones geológicas en la parte oriental del Neuquén y en el territorio del Río Negro. Dir, Gen. Minas, Geol. Hidrografía (Geol.) 2: 3*22.

- 1927. Sobre la facies lacustre Senomaniana de los estratos con dinosaurios y su fauna. Bol. Acad. Nac. Cienc. Rep. Argent. (Cordoba) 30: 383-405.

Williston, S. 1903. North American plesiosaurs. Field Columbian Mus. 73 (Geol. 2); 1-77.

- 1906. North American plesiosaurs: Elasmosaurus, Cimoliasaurus, and Polycolylus. Am.J. Sci. 4: 221236.

Wilson, J. A. 1999. A nomenclature for vertebral lami- nae in sauropods and other saurischian dinosaurs. J. Vert. Paleont. 19: 639-653.

- 2002. Sauropod dinosaur phylogeny: critique and cladistic analysis. Zool. J. Linn. Soc. 136: 217-276.

Wilson, I. A. \& P. C. Sereno. 1998. Early evolution and higher - level phylogeny of sauropod dinosaurs. Soc. Vert. Paleont. Memoir (Suppl. J. Vert. Paleont. 18[2]) 5: 1-68.

Wilson, J. A. \& R. Upchurch. 2003. A revision of Titanosaurus Lydekker (Dinosauria - Sauropoda), the first dinosaur genus with a 'Gondwanan' dis" tribution. J. Syst. Palaent. 1(3): 125-160.

Wilson, J. A. and, M. T. Carrano. 1999. Titanosaurs and the origin of "wide gauge" trackways: a biomechanical and systematic perspective on sauropod locomotion. Paleobiology 25:252m267.

Woodward, A. S. 1901. On some extinct reptiles from Patagonia of the genera Miolania, Dilynisia, and Genyodectes. Proc. Zool. Soc. London 1901: 169-184.

- 1906. On a tooth of Ceratodus and a dinosaurian claw from the Lower Jurassic of Victoria, Australia. Ann. Mag. Nat. Hist. (London) 7: 1-3.

Wu, X. C. 1994. Late Triassic-Early Jurassic sphenodontians from China and the phylogeny of the Sphenodontia. In: Fraser, N. C. and Sues, H-D (eds.), In the Shadow of the dinosaurs: Early Mesozoic tetrapods, pp. 38-69, Cambridge: Cambridge University Press.

Zaher, H. D., M. C. Luanger, E. Fara, I. S.Carvalho \& J.T. Arruda. 2003. A mais antiga serpente (Anilioidea) brasileira: Cretáceo Superior do Grupo Bauru, General Salgado, SP. Paleontologia em Destaque 44: 50-51. 
Appendix. Table of measturements of the postcranial bones of Bonatitan reigi gen. et sp. nov. An asterisk (*) indicates an estimated measurement.

Cervical vertebra (MACN-PV RN 1061)

Height of centrum (anterior)

Width of centrum (anterior)

$30 \mathrm{~mm}$

Length of centrum

$32 \mathrm{~mm}$

$124 \mathrm{~mm}$

Dorsal vertebra (MACN-PV RN 821)

Total height.

Height of centrum

$230 \mathrm{~mm}^{*}$

Width of centrum

$72 \mathrm{~mm}$

Length of centrum

$66 \mathrm{~mm}$

Distance between prezygapophyses

$91 \mathrm{~mm}$

Anterior caudal vertebra (MACN-PV RN 821)

Total height

Height of centrum

$49 \mathrm{~mm}$

Width of centrum

$210 \mathrm{~mm}$

Total length of centrum

$86 \mathrm{~mm}$

$83 \mathrm{~mm}$

Length of the centrum without posterior articular surface

$93 \mathrm{~mm}$

$57 \mathrm{~mm}$

Middle caudal vertebra (MACN.PV RN 821)

Neural arch height

Maximum distance between

prezygapophyses

Maximum distance between

postzygapophyses

Distance between prezygapophysis and anterior border of neural spitse

\section{$75 \mathrm{mmm}$ \\ $56 \mathrm{~mm}$ \\ $38 \mathrm{~mm}$ \\ $73 \mathrm{~mm}$ \\ $363 \mathrm{~mm}$ \\ $139 \mathrm{~mm}$ \\ $109 \mathrm{~mm}$ \\ $54 \mathrm{~mm}$}

Humerus (MACN-PV RN 821)

Total length

Proximal width

Distal width

Minimum transversal diameter of the diaphysis

Ulna (MACN-PV RN 1061)

Total length

Proximal width

Distal width

$185 \mathrm{~mm}$

$83 \mathrm{~mm}$

$69 \mathrm{~mm}$

\section{Radius (MACN-PV RN 1061)}

Total length

$195 \mathrm{~mm}$

Proximal width

$85 \mathrm{~mm}^{*}$

Distal width

$60 \mathrm{~mm}^{*}$

Femur (MACN-PV RN 821 and MACN-PV RN 1061)

Total length

Proximal width

Distal width

$585 \mathrm{~mm}$

$158 \mathrm{~mm}$

$455 \mathrm{~mm}$

$145 \mathrm{~mm}$

$125 \mathrm{~mm}$

Tibia (MACN-PV RN 821 and MACN-PV RN 1061)

Total length

Proximal width

$373 \mathrm{~mm}$

$300 \mathrm{~mm}$

Distal width

$114 \mathrm{~mm}$

Fibula (MACN-PV RN 821)

Total length

Proximal width

$95 \mathrm{~mm}^{*}$

$69 \mathrm{~mm}$

Distal width

$385 \mathrm{~mm}$

$85 \mathrm{~mm}$

$50 \mathrm{~mm}$

Metatarsal I (MACN PV RN 821)

Total length

$76 \mathrm{~mm}$

Proximal width

$48 \mathrm{~mm}^{*}$

Distal width

$39 \mathrm{~mm}^{*}$

Metatarsal III (MACN-PV RN 1061)

Total length

Proximal width

$47 \mathrm{~mm}$

Distal width 